4 nordon 



\section{Energy efficiency in the Nordic building sector}

- potentials and instruments

Karin Ibenholt and Katarina Liljefors

TemaNord 2009:562 
Energy efficiency in the Nordic building sector

- potentials and instruments

TemaNord 2009:562

(C) Nordic Council of Ministers, Copenhagen 2009

ISBN 978-92-893-1908-9

Copies: 0

Printed on environmentally friendly paper

This publication can be ordered on www.norden.org/order. Other Nordic publications are available at www.norden.org/publications

Printed in Denmark

Nordic Council of Ministers

Store Strandstræde 18

DK-1255 Copenhagen K

Phone (+45) 33960200

Fax (+45) 33960202

www.norden.org

\section{Nordic Council}

Store Strandstræde 18

DK-1255 Copenhagen K

Phone (+45) 33960400

Fax $(+45) 33111870$

\section{Nordic co-operation}

Nordic cooperation is one of the world's most extensive forms of regional collaboration, involving Denmark, Finland, Iceland, Norway, Sweden, and three autonomous areas: the Faroe Islands, Greenland, and Åland.

Nordic cooperation has firm traditions in politics, the economy, and culture. It plays an important rol in European and international collaboration, and aims at creating a strong Nordic community in a strong Europe.

Nordic cooperation seeks to safeguard Nordic and regional interests and principles in the global community. Common Nordic values help the region solidify its position as one of the world's most innovative and competitive. 


\section{Content}

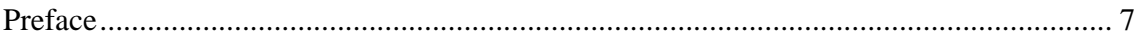

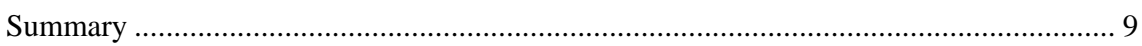

Energy efficiency in the building sector ................................................................ 9

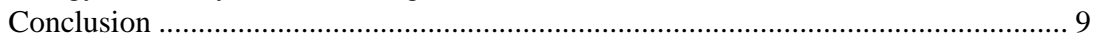

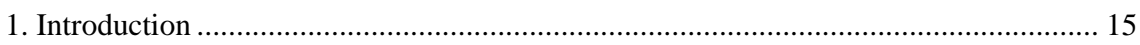

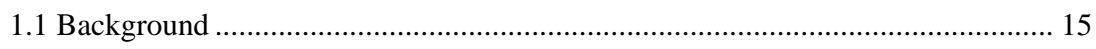

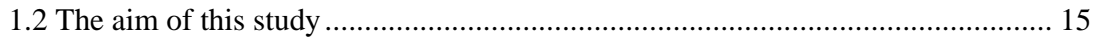

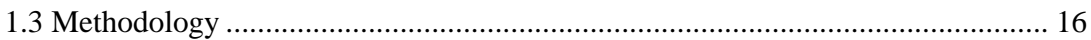

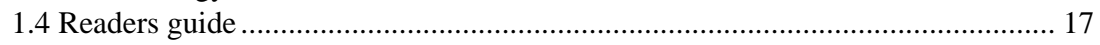

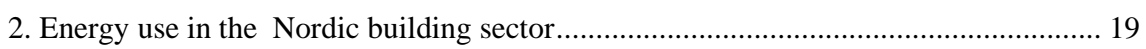

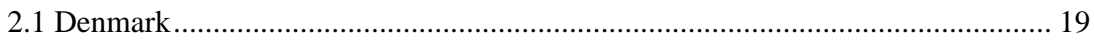

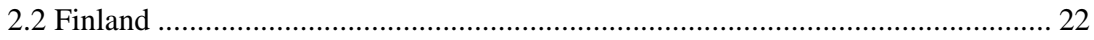

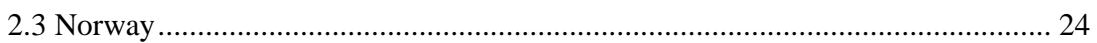

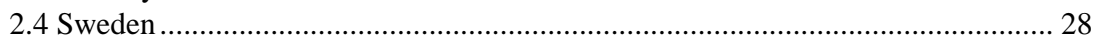

2.5 Comparing the countries ................................................................................... 31

3. Policies for increased energy efficiency - theoretical foundation............................... 37

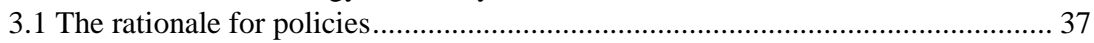

3.2 The design of measures ........................................................................................ 42

4. Policies for energy efficiency in the Nordic countries .................................................. 49

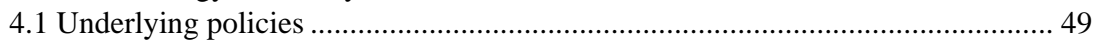

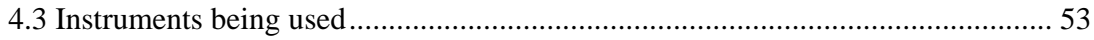

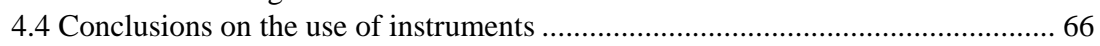

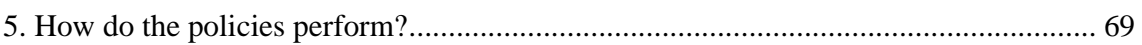

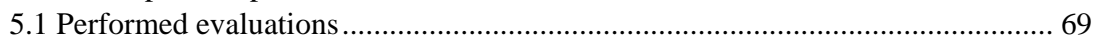

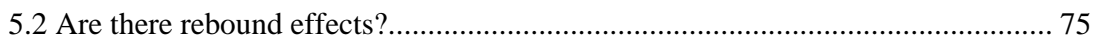

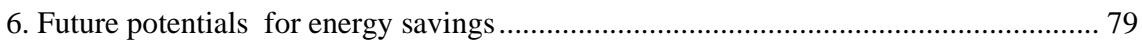

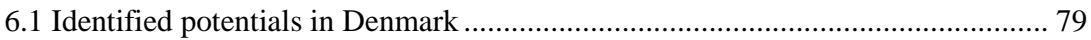

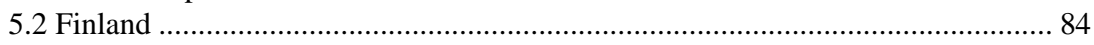

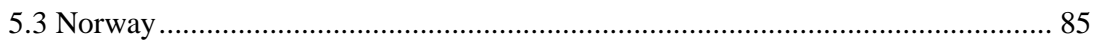

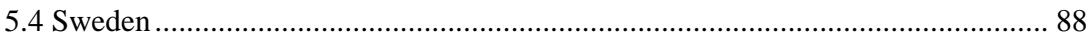

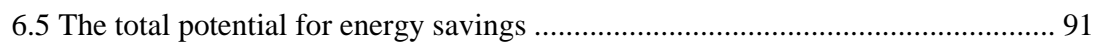

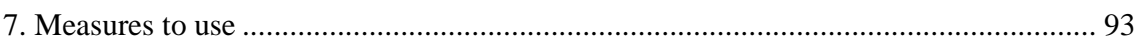

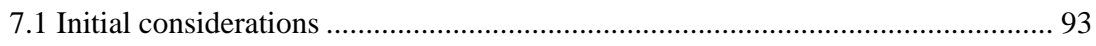

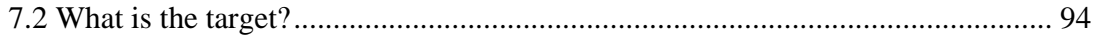

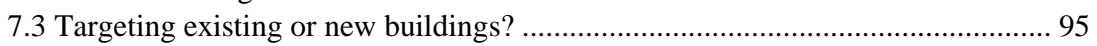

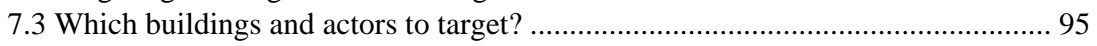

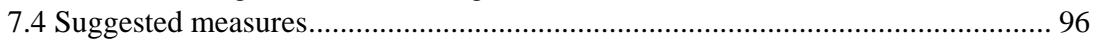

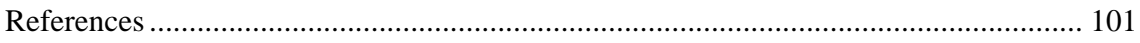

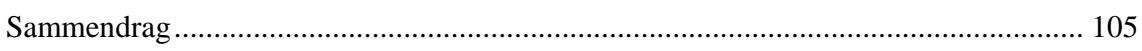

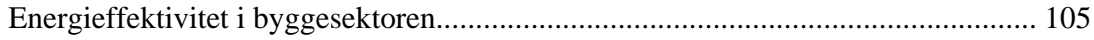

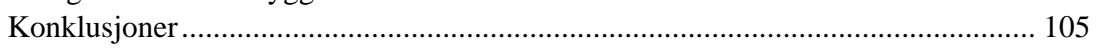

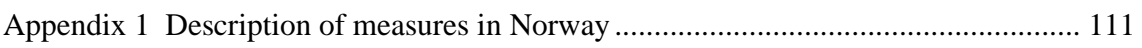

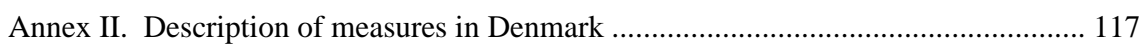

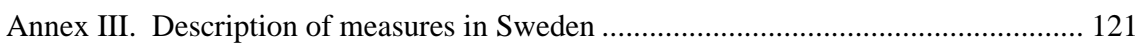

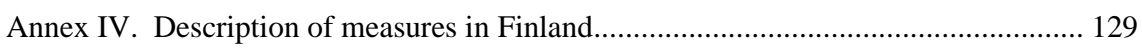





\section{Preface}

This report discusses some economic aspects of promoting energy efficiency in the building sector, with the purpose to give input to the Nordic countries in their work related to EU's action plan for environmental technology (ETAP), the targets of the Lisbon strategy and the EU Commission's initiative "A lead market initiative for Europe" from May 2008, as well as the work to reach national climate goals. The report discusses barriers that hinder use of more energy efficient technologies in the building sector and measures that can help overcome these barriers. It also assesses energy use in buildings, existing policies and measures intended to reduce energy use in this sector and the potential for reduced energy use. The project was commissioned by the Nordic Council of Ministers working groups for Integrated Product Policy and Environmental Economics, and it has been guided by a steering group consisting of Jan-Erik Tveter (Norwegian Pollution Control Agency, SFT), Mattias Ankarhem (Ministry of Finance, Sweden), Ari Nissinen (Finnish Environment Institute) and Stig Arve Malmedal (Ministry of Finance, Norway). The project has been carried out by Econ Pöyry in Norway assisted by Pöyry in Sweden, Denmark and Finland. Karin Ibenholt, Econ Pöyry, has been project leader.

June 2009,

Claus Egeris Nielsen

Chairman, the HKP working group

(for Sustainable Consumtion and Production)

of the Nordic Council of Ministers
Ulrica Lindstedt

Chairwoman, the MEG working group

(for Environmental Economics)

of the Nordic Council of Minsters 



\section{Summary}

\section{Energy efficiency in the building sector}

In order to achieve sustainable development, it is important to develop and use technologies with lower environmental impact. An important way to do this can be through lower energy use. Energy use in buildings, including construction, is presumed to make up approximately 40 percent of stationary energy use. Increased energy efficiency in this sector can therefore have a substantial effect on overall energy use, promoting sustainability and achievement of national targets for reduced emissions of greenhouse gasses. Several studies have, however, identified substantial barriers for increased energy efficiency in this sector. These include barriers related to the way the sector is organised, its cyclical nature and a lack of information about energy-saving possibilities. Based on the need for a shift towards more sustainable buildings, the Nordic Council's working groups for integrated product policies and for environment and economy commissioned an assessment of economic aspects of energy efficiency in the building sector in the Nordic countries.

The short-term aims of the project have been to provide increased understanding on how instruments for increased energy efficiency can contribute to reduced environmental impact and on what measures are most effective for promoting new technologies in the building sector - while ensuring a positive overall environmental effect. Another aim is to provide input for the Nordic countries in their work to further develop an EU action plan for environmental technologies (ETAP). The outcome of the project should also be of use in the countries' follow-up on national climate targets. The report covers Denmark, Finland, Norway and Sweden.

\section{Conclusion}

The overall conclusion is that there is an economic potential for increased energy efficiency in the building sector in the Nordic countries. However, the size of this potential is difficult to assess, partly because of insufficient statistics on the energy use in this sector. At the same time there are several barriers that hinder the use of more efficient solutions, and present policies towards energy efficiency have so far not been able to successfully tear down these barriers. The energy efficiency policies in place today are based on addressing the climate problem and the need to secure energy supply, but it is mainly for the latter that energy efficiency is a direct and appropriate measure. Promoting energy efficiency in order to 
reduce emissions related to climate change should be handled with care, since these policies might induce large rebound effects that can cause emissions to be reduced very little or not at all. If the target is related to securing energy supply efficiency measures is probably more accurate.

\section{Climate and energy supply are the main policy drivers}

There are several rationales for public intervention to increase energy efficiency. These rationales can be found in different forms for market failures that exist regardless of political targets, e.g., the existence of externalities, market power and asymmetric information. Other justifications are based on political targets, for instance regarding emissions of greenhouse gasses and security of energy supply. Many energy policy measures and targets in the Nordic countries are grounded in policies and targets set by the European Union. In turn, EU energy policy objectives are formulated as part of the wider EU "climate objectives", and the socalled "20 2020 by 2020" policy objective (a reduction of CO2 emissions by 20 percent by 2020, an increase of the share of renewable energy to 20 percent by 2020 and an improvement by 20 percent in energy efficiency by 2020). The energy policies in the Nordic countries are all based on the climate challenge, the need to secure supply and to ensure a competitive market with reasonable prices. Instruments to promote energy efficiency are normally part of the two first challenges. All countries use a mix of fiscal, regulatory and informational instruments. Sweden and Denmark seem to be the countries with the most diverse portfolio of measures, whereas Norway primarily relies on investment support. The prime instrument in Finland is voluntary agreements, but there also exist several other types of measures.

\section{Unclear what environmental effects the policies have had}

Existing and past policies and measures have been evaluated to varying degrees, and the scope of these evaluations also varies. Therefore it is difficult to clearly identify the most efficient measures. Most evaluations focus on how the measures have been implemented, as well as administrative issues, such as additionality. Actual savings of energy and reductions of climate emissions are assessed to a lesser degree, but when this is the case, the savings are often found to be smaller than the target. Several evaluations show that the savings probably would have been realized even without the support, i.e., that the measures have a low additionality.

\section{There is an economic potential for more energy efficient solutions}

During the past 20 years, major differences have appeared in the energyuse trends of the Nordic countries. Many of these differences come from 
structural, geographical and policy differences. However, trends in energy use in the household sector share one common characteristic in that they are all decreasing, on average. The observed flattening out of energy use over the recent years has several causes, including increased energy prices, saturation trends, improved efficiency, climate change and conversion to different energy carriers.

Even with a flattening energy use, studies have identified a substantial remaining potential to save energy in the building sector. However, the studies differ in methodologies and assumptions, and can therefore be hard to compare, while it is also difficult to transfer the results from one study to others.

\section{The initial energy savings can be offset by rebound effects}

The rebound effect refers to the idea that some or all expected reductions in energy use as a consequence of energy efficiency improvements are offset by increased demand for energy. Several empirical studies confirm the existence of rebound effects related to most actions for energy efficiency. The estimated effects vary significantly: While some studies conclude that the rebound effect is so weak that it can be ignored, others find that the effects are big enough to more than wipe out the initial savings. There is also reason to believe that the rebound-effect can be smaller in the short term than in the long term, due to long-term behaviour change that can be significant for the total use of resources.

In order to avoid rebound, measures to improve energy efficiency should target those energy services which have a low price elasticity. (An example of these might be indoor temperature settings.) The investment cost of the efficiency measure for the actor making the investment, must not be too low, indicating that large state funded subsidies, which reduces the cost for the actor may incur high rebound effect.

\section{The optimal policy includes several instruments and measures}

Our mapping shows that there are already several policies and measures in place that aim to increase energy efficiency, both in general and towards the building sector in particular. One might therefore ask if there is a need for additional measures targeting the building sector. One argument for additional measures is that there still is a lot of barriers for energy efficiency in this sector and that present effort on energy efficiency most likely is below what is social optimal.

It is however, important to recognise that there always will exist an energy efficiency gap, meaning that there will always be a potential for profitable efficiency gains/investments that are not being performed, partly due to lack of complete information (without this being a barrier that justifies policy measures) and budget constraint (it is not possible to 
perform all profitable investments at the same time). To what extent the authorities should use political measures to reduce this gap, is partly a question of whether the barriers causing the gap can be considered a social market failure and partly if the expected gains (reduced energy use and/or $\mathrm{CO}_{2}$ emissions) exceed the costs of implementing the measure.

\section{Need for strict building regulations}

Targeting the building industry is very important, since construction methods and installed energy systems will form the basis for energy demand for a long time to come. A building (at least the carrying construction) could have a technical life time spanning from 10 to several hundred years, but functional adaptations/renovations are generally required every $10-20^{\text {th }}$ year. For the building industry it is important to ensure that energy is included in the planning process, and not taken into consideration after the building has been designed. Measures towards the building sector should aim at overcoming the identified barriers, such as structural issues, lack of competence and financial constraints. Relevant measures are competence building, strict building regulations, cooperative measures (for instance agreements between the industry and the authorities) and limited financial support.

\section{The real price for energy must be reflected in the end-user prices}

The users of buildings should be exposed to the "right" energy price through taxation or other market-based instruments (for instance white certificates). If the right energy price implies increased end-user prices, the authorities can provide information about the social costs being addressed by the increase, as well as possibilities to save energy, as this could make the increase more socially acceptable. Information and public advice that is either provided for free or at a low cost can also be used to reduce informational barriers, inertia and implementing costs (i.e., costs other than financial). Financial support to energy efficient investments should be used with great care in this sector, since there is a rather high risk of rebound if the savings become "too cheap".

\section{The public sector should be a pioneer for energy efficient solutions}

The public sector could have a pioneering role when it comes to energy use, partly based on a need "to order one's own house" before demanding that the private sector does so. This could for instance be done by demanding that public builders and owners include energy efficiency in procurement processes, both when building or renovating and when renting premises. Public-sector demand can also help lower costs for such services by helping relevant service suppliers achieve scale efficiencies. 
Labelling can reduce the split incentive barrier

To overcome the, barrier of different (or split) incentives between builder, owner and user of a building, reducing measures that affect both the supply and demand side are necessary, but with a focus on creating a demand for energy efficient technologies. Mandatory energy labelling of buildings, as required in the EU Energy Performance in Buildings Directive, might induce a demand for buildings with lower energy use, and also make builders and owners focus on energy in a life-cycle perspective - not just in the construction phase. But if such measures actually will affect energy efficiency is partly a question of energy prices. If energy costs are an important part of total operational costs (including for instance rent and mortgages) then energy labelling can be effective; otherwise it is likely to have less effect. In order to be effective, the energy labelling must also be credible, and some sort of control mechanism should be present.

Cost and benefits of new measures should be carefully assessed

Before introducing new measures, existing measures should be carefully assessed, with the aim of identifying if and why they are not sufficient. It is also important to considerer how other policies and regulations affect energy efficiency. All measures suggested for implementation should also be carefully evaluated ex-ante, ensuring that the benefits exceed the social costs of implementing them, i.e., a thorough cost benefit analysis should be performed that, inter alia, addresses the rebound issue. It is also useful to design the measures in such a way that it is possible to evaluate them ex-post. 



\section{Introduction}

\subsection{Background}

In order to reach sustainable development it is important to develop and use technologies with lower environmental impact, for instance through lower energy use. In 2007, The Nordic council of ministers working group for integrated product policy (NMRIPP) undertook a project about green markets and green technologies (Green Markets and Cleaner Technologies, GMCT), aimed at promoting green technologies based on Nordic experiences. Successful Nordic green technologies were analyzed in order to identify success factors concerning implementation and marketing, with a special focus on transferability to other sectors. The technologies included in the project were from three different sectors: buildings, pulp and paper, and mobile phones.

The analysis of the building sector showed that structural issues, both on the supply and demand side, are important for the innovation rate and hence the development and use of new technologies (Emtairah et al., 2008). In general the innovation rate is low in this sector, and this also holds for the will or ability to use more energy efficient solutions. In addition, this sector is cyclically sensitive, contributing to less focus on long-term strategies. There are several other studies that confirm the existence of many barriers for energy efficiency in this sector, including Econ Pöyry (2007a) and Ryghaug and Sørensen (2009).

At the same time the building sector, including the use of the buildings, are usually presumed to make up approximately 40 percent of stationary energy use, see for instance Enova (2008). Increased energy efficiency in this sector can therefore have a substantial effect on overall energy use, promoting sustainability and forwarding achievement of national targets for reduced emissions of greenhouse gasses.

Based on the challenges identified in the GMCT study of the building sector and the importance this sector has on the energy use, the Nordic Council's working groups for integrated product policies and for environment and economy commissioned an assessment of economic aspects of energy efficiency in the building sector in the Nordic countries.

\subsection{The aim of this study}

The long term aim of this project is to give a foundation for the Nordic countries to use in the work of further developing an EU action plan for environmental technologies (ETAP), reaching the targets in the Treaty of 
Lisbon and implement the initiative from the EU Commission in May 2008 (A lead market initiative for Europe). The outcome of the project should also be of use in the countries' follow-up on national climate targets.

The short term aim is to provide increased understanding on how instruments for increased energy efficiency can contribute to reduced environmental impact and what measures are most effective in order to promote new technologies in the building sector, at the same time assuring a positive total environmental effect.

There are five issues that are discussed in this report:

- Which policies, targets and instruments are used in order to promote energy efficiency in the building sector in the Nordic countries?

- What are the environmental gains, focusing on climate, from increased energy efficiency, and are there any national differences?

- What is the potential for increased use of energy efficient buildings, which have a smaller environmental impact, in the Nordic countries?

- How are the gains from increased energy efficiency and savings used?

- What is an optimal policy for energy efficiency in the building sector?

\subsection{Methodology}

The study is mainly a desk study, were we have assessed existing literature and official statistics. We aimed at covering the most recent studies and statistics, to the best of our knowledge. We have not collected any new data, but have in some instances contacted representatives for energy authorities to complement information in available studies and statistics.

The study aims at covering both dwellings and commercial buildings, and both new and existing buildings. However, the available statistics concerning energy use have certain limitations and this holds for commercial buildings in particular where none of the Nordic countries have sufficient statistics. Additionally, the inconsistency of the statistics make it difficult to compare building sector energy use over time and between countries.

This study covers Denmark, Finland, Norway and Sweden, and excludes Iceland. The main reason for this is Iceland's unique energy situation compared to the other Nordic countries, with geothermal energy covering more than 80 percent of the space heating requirement. Moreover, we have had difficulties collecting information about Iceland. 


\subsection{Readers guide}

The report starts (chapter two) with a short description of the building sector and the associated energy use in the Nordic countries. In chapter three we discuss optimal energy efficiency - when is energy use considered optimal, and why optimality is unobtainable in an unregulated economy. The fourth chapter discusses energy policies and regulations that aim at bring energy use (or energy efficiency) to an optimal level in the Nordic countries. In chapter five we focus on what effect some policies and instruments have had on energy use in buildings, and if there are certain instruments that work better than others. In this chapter we also discuss the existence of rebound, i.e., that some of the initial gains in reduced energy use are counteracted by an increase in energy use. In chapter six we discuss the identified potentials for increased energy efficiency in the building sector, in order to understand how much energy savings that can be realized with present technologies. In the last chapter we discuss if there is a need to use further policies to spur energy efficiency in the building sector, and what types of instruments that are most likely to deliver. 



\section{Energy use in the Nordic building sector}

This chapter gives an overview of energy use in the building sector in each country. As mentioned in the introduction, the official statistics for energy use in each countries building sector are not directly comparable either over time or between countries. Most statistics are structured around the energy using sector, i.e., households, industry and commercial sectors, and not based on the purpose of the energy consumption. It is therefore difficult to separate energy use for heating purposes from energy use for electrical equipment and business operations. There are some cross-sectional analyses over energy use in different sectors, but not as time series.

The description of each country starts with the building sector, primarily number of buildings and type of buildings. Following this, we describe the energy use in buildings, including what kind of energy carriers is used.

\subsection{Denmark}

\subsubsection{The building sector in Denmark}

The building stock of Denmark is, like in most countries, primarily composed of residential dwellings, accounting for approximately 60 percent of the total stock (Statistics Denmark, 2008). Industrial and commercial buildings define the next largest subgroup, about 28 percent of the total buildings. The definitions used by Statistics Denmark additionally group educational, institutional, holiday/leisure, and cultural (e.g., churches) separately as "other buildings," which make-up the remainder.

Additionally, about 43 percent of all dwellings in Denmark are detached, with 41 percent comprised of multi-dwelling units (see table 2.1).

Table 2.1 Dwellings by type of dwelling, Denmark $(2007,2008)$

\begin{tabular}{llllll}
\hline & Detached & $\begin{array}{l}\text { Terraced, linked } \\
\text { or semi-detached }\end{array}$ & Multi-dwelling & Other & Total \\
\hline 2007 & 1068484 & 367306 & 1029128 & 219137 & 2684387 \\
2008 & 1076634 & 375138 & 1039775 & 218750 & 2710297 \\
\hline
\end{tabular}

Source: Statistics Denmark 
According to Statistics Denmark, the average number of occupants per residential dwelling has decreased significantly from 3.01 persons in 1960 to 2.15 persons in 2007.

In terms of ownership, which can be of particular importance when analyzing the response to different types of policies, the number of rented and owner occupied dwellings are nearly equal, accounting for 43 and 48 percent, respectively.

\subsubsection{Energy use in the Danish building sector}

Figure 2.1 points to the significant energy using sectors in Denmark, where households and transportation lead the list. Exploring the underlying characteristics of energy usage within the household sector will, thus, enable better policy recommendations leading to better energy efficiency within the building sector.

Figure 2.1Final energy consumption by sector in Denmark, (Climate Adjusted)

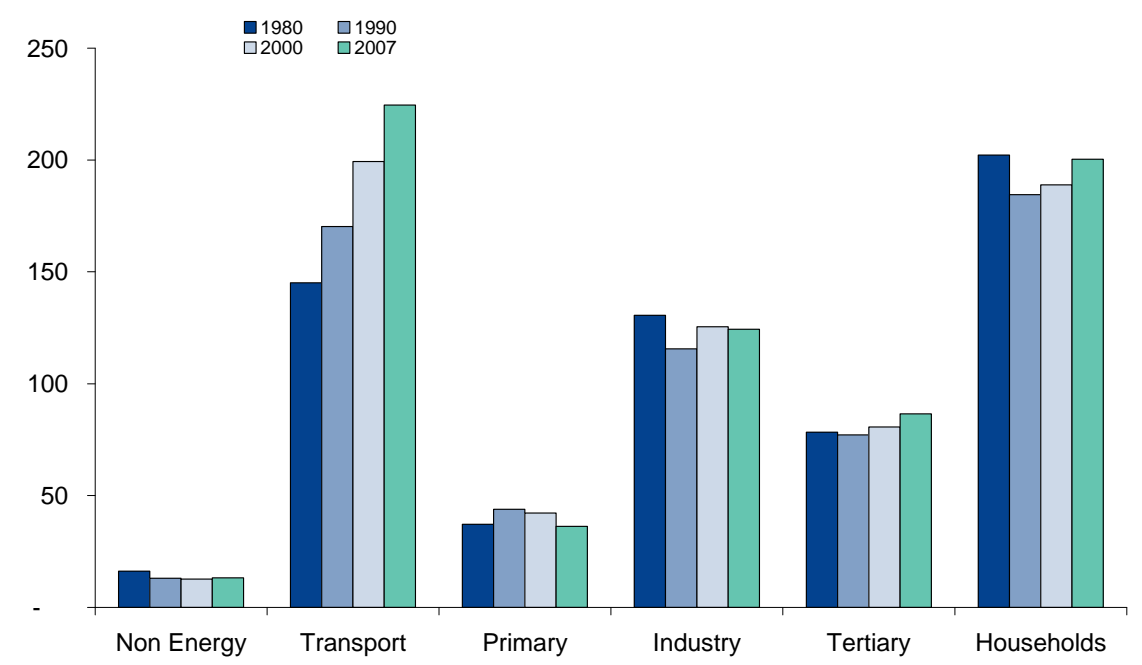

Source: Danish Energy Authority

Focusing on households, heating makes up the largest portion of energy use in all Nordic countries, see for instance Unander et al. (2004). In 2007 heating constituted 83 percent of the energy use in households (Danish Energy Agency, 2008). In 2007 the average energy use per household was 79,2 GJ, slightly lower (0.2 percent) than in 2006 (Danish Energy Agency, 2008). Compared to 1990 the energy use per household has decreased with 3.6 percent, see figure 2.2 and 2.3. As can be seen from figure 2.4 most of the dwellings are connected to district heating or other central heating technologies.

While energy consumption for heating per dwelling has been reduced since 1980, energy use for electrical appliances and lighting increased substantially, by about 35 percent. Thus, electricity consumption is the 
most likely area for energy efficiency improvements in the building sector. Danish households have made measureable progress in decreasing overall energy use, mostly through improved space heating solutions, whereas further progress will likely focus on electricity consumption, including major electrical appliances, such as refrigeration, and lighting.

Figure 2.2 Unit consumption per dwelling by use (climate adjusted), toe/dwelling

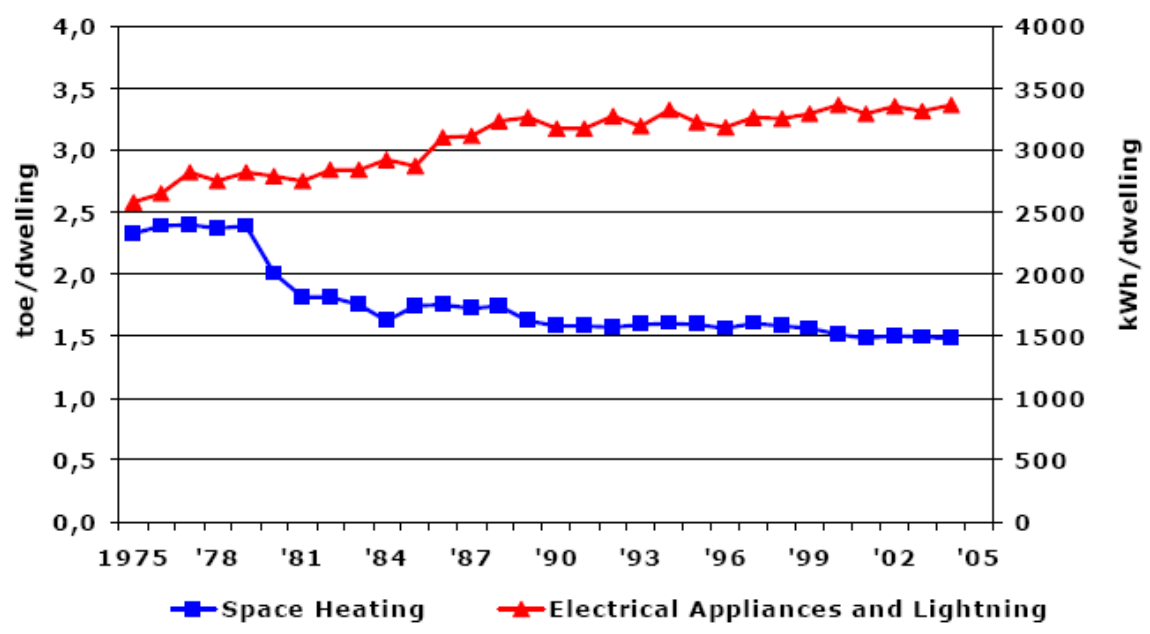

source: Danish Energy Agency

Figure 2.3 Unit consumption per dwelling, toe/dwelling total energy and electricity (climate adjusted)

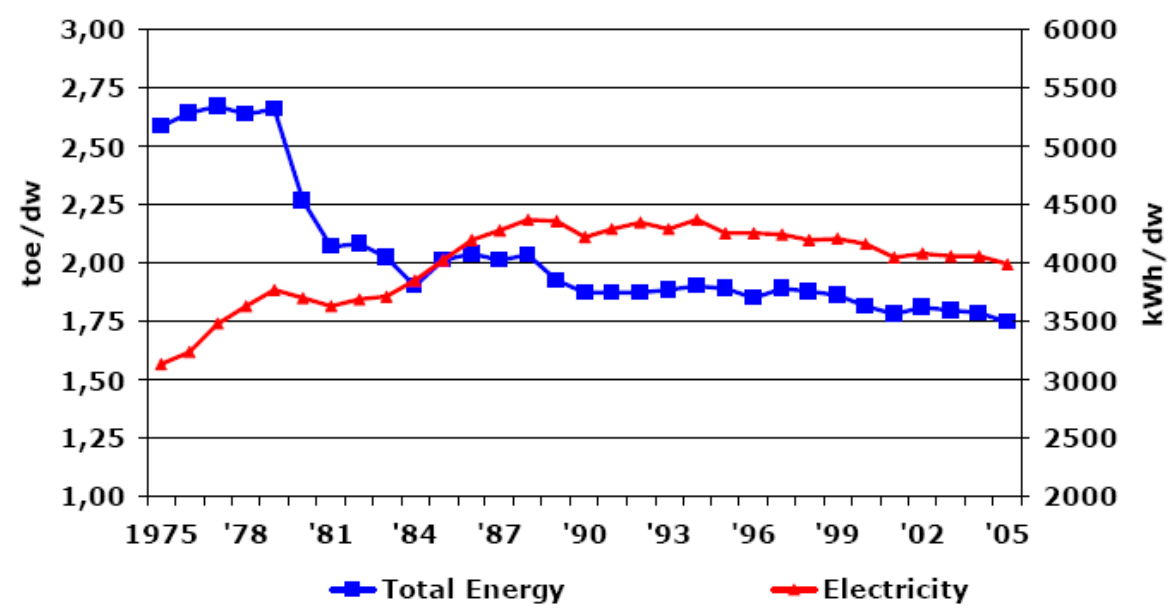


Figure2.4 Occupied dwellings by heat, 2008

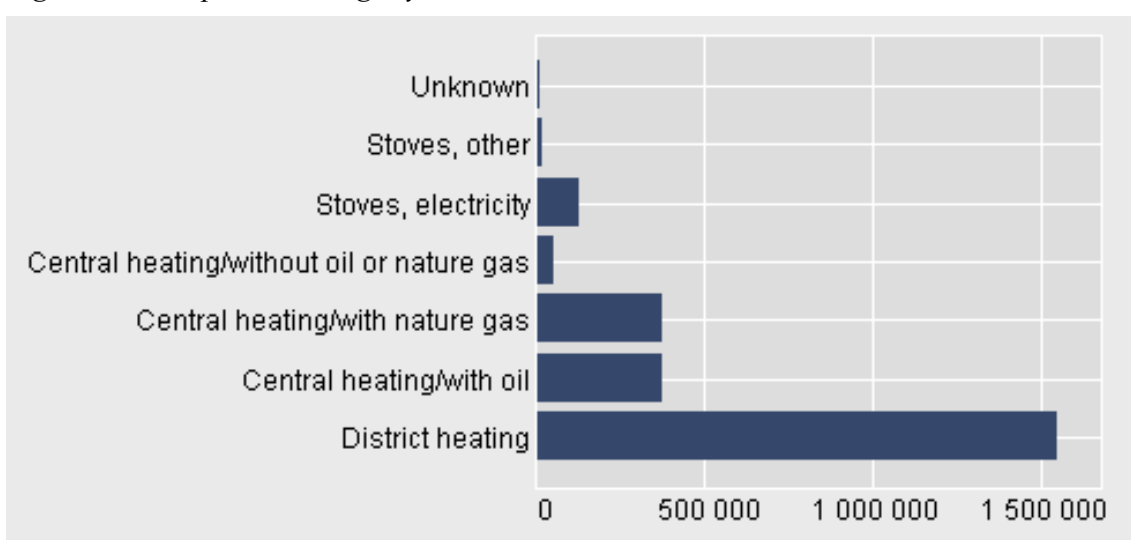

Source: Statistics Denmark

\subsection{Finland}

\subsubsection{The building sector in Finland}

There are approximately 1.4 million buildings in Finland (Statistics Finland, 2008). In 2000 the entire building stock was equal to 500 million $\mathrm{m}^{2}$, and it is expected to reach nearly 550 million $\mathrm{m}^{2}$ in 2010, based on an annual net increase of between 0.5 and 1 percent. ${ }^{1}$ Residential buildings constitute as much as 86 percent of total buildings, i.e., 1.2 million dwellings. Nearly 90 percent of the dwellings are detached, 5 percent terraced and 5 percent multi-dwellings.

There were nearly 2.5 million households in Finland in 2007 (Statistics Finland, 2008). The average size of a household is 2.1 occupants and $80.5 \mathrm{~m}^{2}$.

\subsubsection{Energy use in the Finnish building sector}

Energy statistics indicates that heating of residential and service buildings accounted for 22 percent of the end-use of energy in 2003 (see figure 2.5). The share of the entire building stock comes to almost 40 percent of energy end-use consumption in Finland.

\footnotetext{
${ }^{1}$ Annual construction of new buildings constitute $1.5-2$ percent of the stock. Stock loss varies between $0.3-2$ percent depending on building type, the average being about 1 percent.
} 


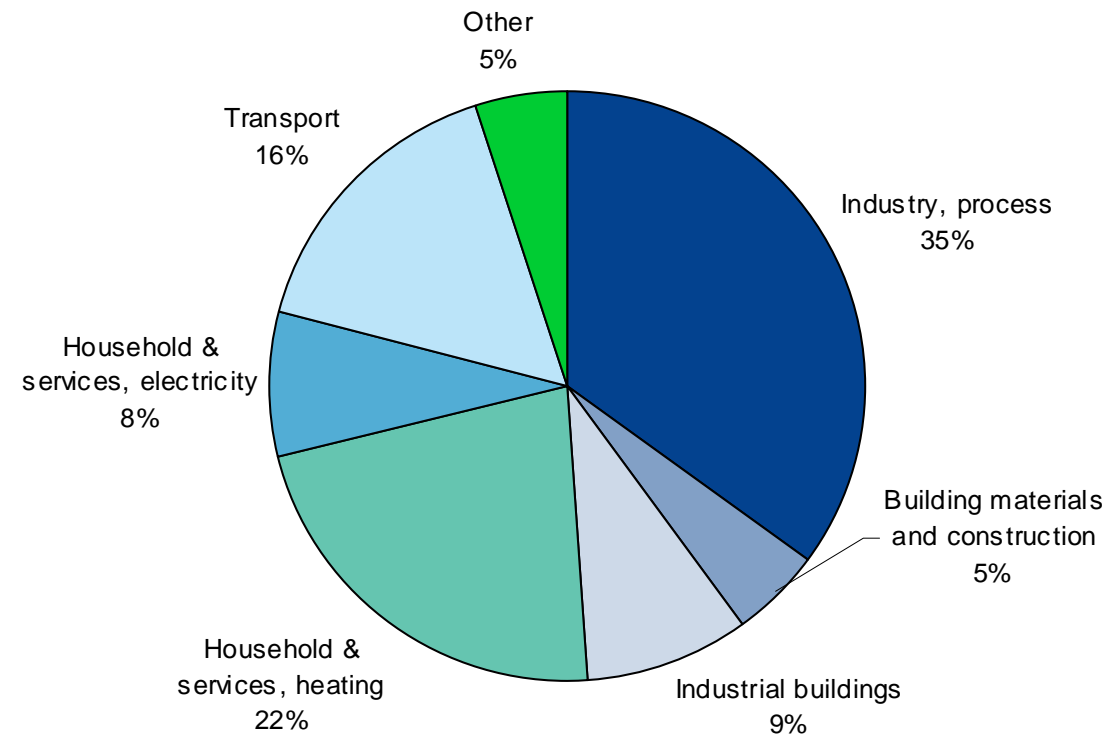

Source; Statistics Finland

The growth and the improving quality level of the building stock have increased energy consumption more than the increasingly energy efficient new production replacing stock loss and energy conservation measures decreased it. Based on the EKOREM ${ }^{2}$ model, the combined consumption of useful heating energy and domestic and building-services energy in residential and service buildings is predicted to increase from 77 $\mathrm{TWh} /$ year in 2000 to $81 \mathrm{TWh} /$ year in 2010 or 5 percent in 10 years (Heljo et al., 2005). Energy statistics indicate that the corresponding figure for 2004 was about $80 \mathrm{TWh} /$ year.

Nearly half of the building stock is connected to district heating. The share of district and electric heating in the building stock continues to increase, while the use of oil heating decreases, due to the different heating-mode distributions of new production and the existing building stock.

In figure 2.6 the average specific energy consumption of housing and service buildings is presented. In Finland the decrease of specific heating energy consumption has halted. The rate of increase of electricity consumption has decreased, but the specific electricity consumption continues to increase. In 2003 the average specific consumption of energy for heating purposes was approximately $48 \mathrm{kWh} / \mathrm{m}^{3}$ and for electricity approximately $18 \mathrm{kWh} / \mathrm{m}^{3}$.

\footnotetext{
2 The EKOREM calculation model was developed by Tampere University of Tecnology, for use in The More eco-efficient use of energy in the building stock project (2003-2005) with the aim to assess the energy consumption and greenhouse gas emissions of the building stock.
} 
Figure 2.6 Development of specific energy consumption in housing and service buildings in Finland (2003)

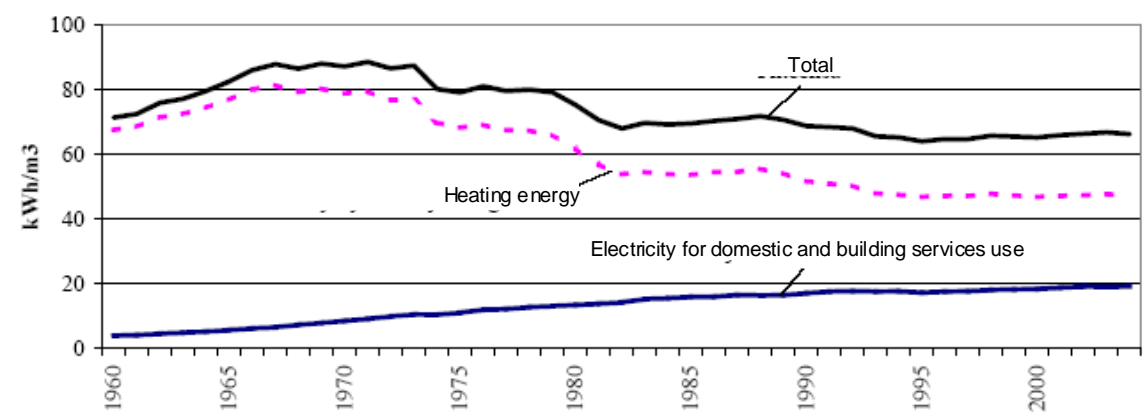

\subsection{Norway}

\subsubsection{The building sector in Norway}

According to Statistics Norway (2008a), the number of buildings in Norway was 3.8 million in January 2008, of which 1.44 million (38 percent) were residential buildings, 0.75 million industrial buildings, 0.42 million holiday houses and 0.89 million garages. 68 percent of the 754,000 industrial buildings are classified as fishery and agricultural buildings.

There are approximately 2.2 million private households in Norway (Statistics Norway, 2008a). More than 50 percent of these live in detached dwellings, 25 percent in terraced dwellings or dwellings with less than 3 floors, and approximately 20 percent live in apartment blocks (multi dwellings), see figure 2.7. According to Econ Pöyry's statistics for resold homes, the average detached dwelling is approximately $152 \mathrm{~m}^{2}$, a terraced dwelling averages $117 \mathrm{~m}^{2}$ and the average flat measures $68 \mathrm{~m}^{2}$. The floor area of the two first categories have increased slightly since the late 1980s, from $150 \mathrm{~m}^{2}$ and $116 \mathrm{~m}^{2}$ respectively, while the floor area of flats has declined substantially in the period, from $79 \mathrm{~m}^{2}$. The number of residents per dwelling was 2.3 in 2001 and almost eight out of ten households own their dwelling.

Due to the strong increase in the building of multi-dwelling buildings over the past years, there were almost 500,000 flats in multi-dwelling buildings in the beginning of 2008. More than 75,000 of these were constructed during the last seven years. 
Figure 2.7 Number of dwellings, by type of building (percent), January 2008, Norway

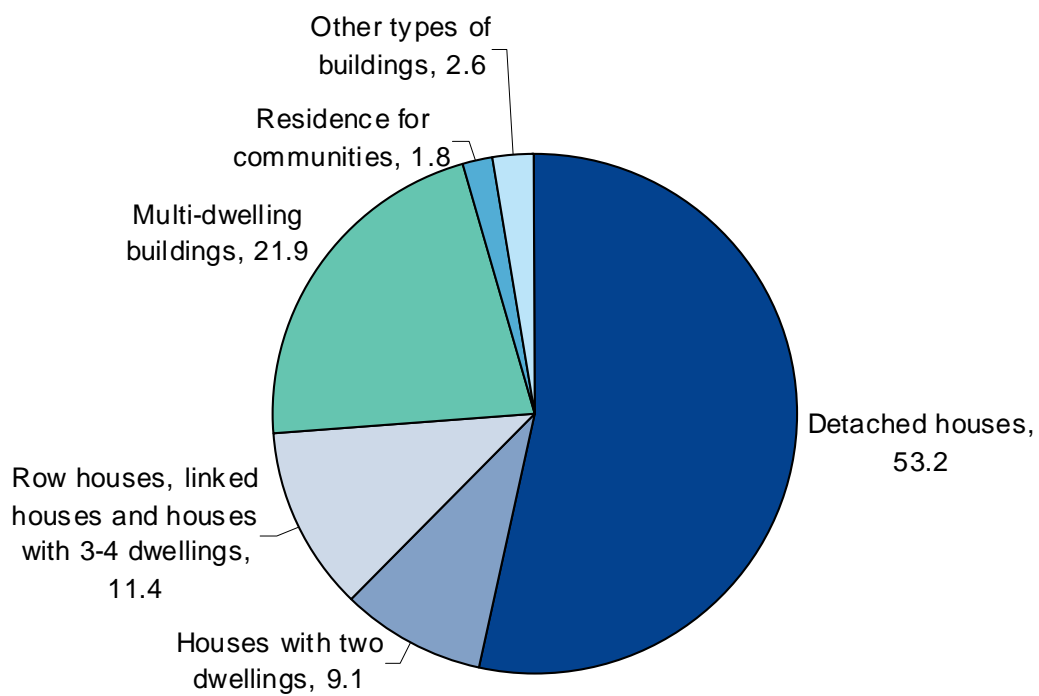

Source: Statistics Norway

Statistics Norway does not present any statistics about commercial buildings, but according to Enova's building statistics (Enova, 2008) commercial buildings constituted 127 million $\mathrm{m}^{2}$ in 2006. This equals approximately one third of the total building area in Norway (see figure 2.8).

Figure 2.8 Total building area and ownership in 2006, Million $\mathrm{m}^{2}$, Norway

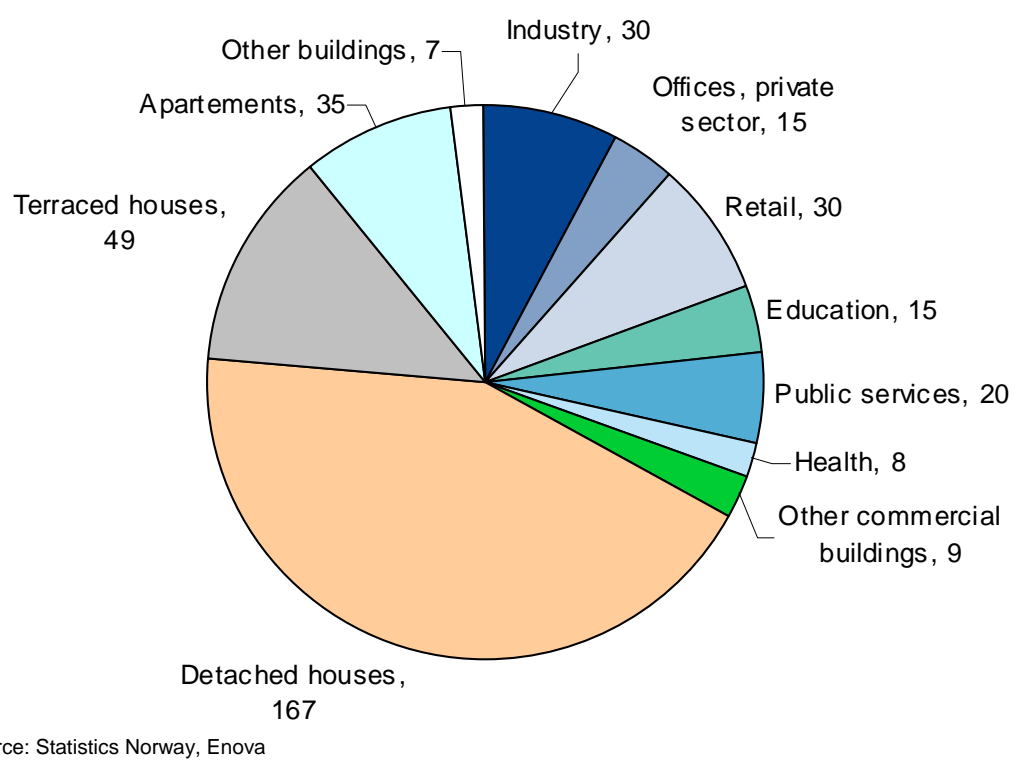




\subsubsection{Energy use in Norwegian buildings}

Energy use in buildings accounts for about 40 percent of total stationary energy consumption in Norway, as in most other countries (Econ, 2007b). Norway has a high share of electricity in its energy consumption and power consumption per capita is roughly 10 times that of the world average. Reasons for this include extensive power-intensive manufacturing, and the fact that electricity is a more common source of heating than in other countries.

Electricity is the most important energy source in Norwegian households, and accounts for about three quarters of the total stationary energy consumption, or about 16,200 kWh in 2006, see figure 2.9.

Figure 2.9 Average energy consumption by dwelling area ( $k$ Wh), 2006

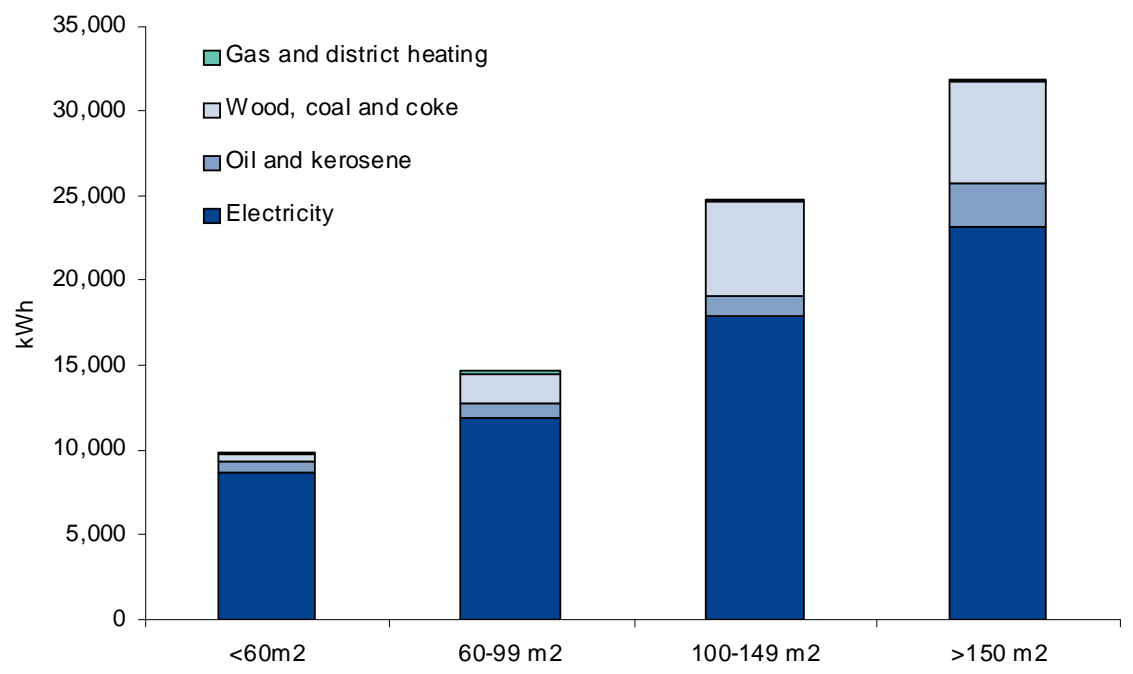

Source: Statistics Norway

During the last years, energy consumption by households has declined (see figure 2.10) at the same time as there has been an increase in dwelling area. This can be explained by higher energy prices, more focus on energy saving, better insulation and more energy efficient electrical equipment (Statistics Norway, 2008b). It should also be noted that larger buildings are more energy efficient per square meter, due to the decreased ratio of external area to internal volume. Thus, the increase in multidwelling units may play a significant factor in the levelling of electricity consumption trend. Another factor that influences energy needs is climatic changes, because a large part of the energy consumption in households is used for heating purposes. Since the end of the 1980s, the temperature has been above the climatic normal for the years 1961-1990, except for 1996. 
Figure 2.10 Households historical stationary energy consumption 1976-2005. GWh.

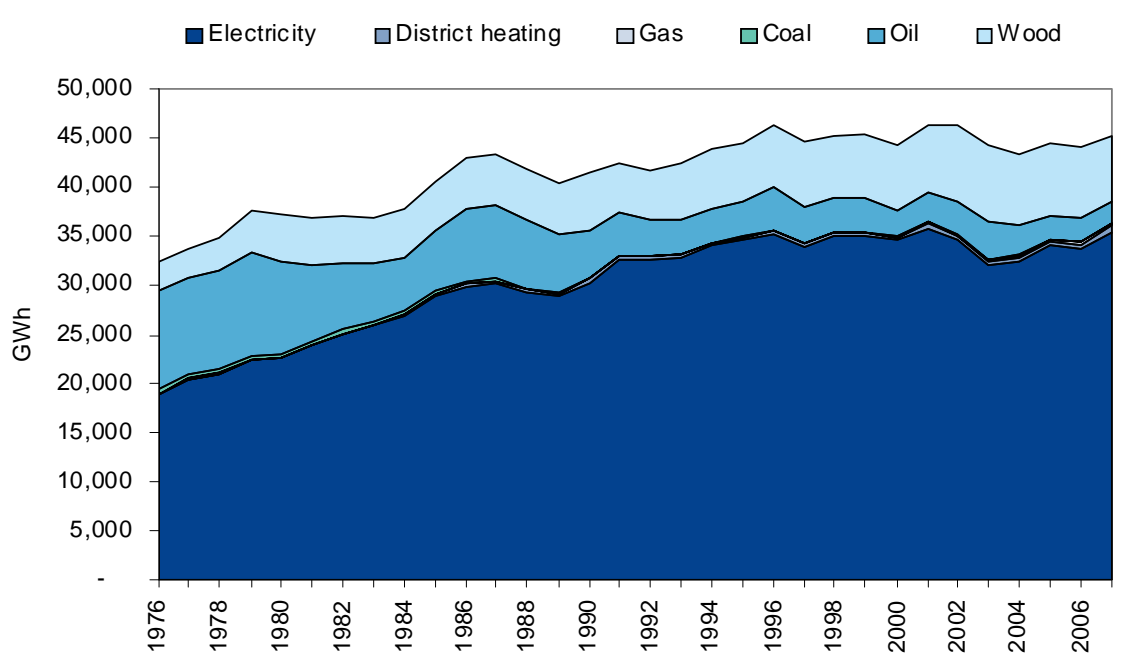

Source: Statistics Norway, Econ Pöyry

Electricity consumption in households increased by an average annual growth rate of 2.8 percent from 1970 to 1999, then decreased again between 2000 and 2005 by 0.4 percent a year. According to Halvorsen et al. (2005) the flattening of growth in electricity consumption over the past ten years is caused by both a flattened growth in number of households and of growth in electricity consumption per household (including a reduction in growth in the so-called el-specific consumption, meaning consumption of electricity to electronic equipment) This is supported by Halvorsen et al. (2007) showing that the factors contributing the most to explain household's electricity consumption is heating equipment, prices and income, plus living area and number of household members.

\section{The Service Sector}

Figure 2.11 shows energy consumption in the service sector from 1976 to 2005, based on data from Statistics Norway. 
Figure 2.11 Historically stationary energy consumption in the public and private service sector 1976-2005. GWh.

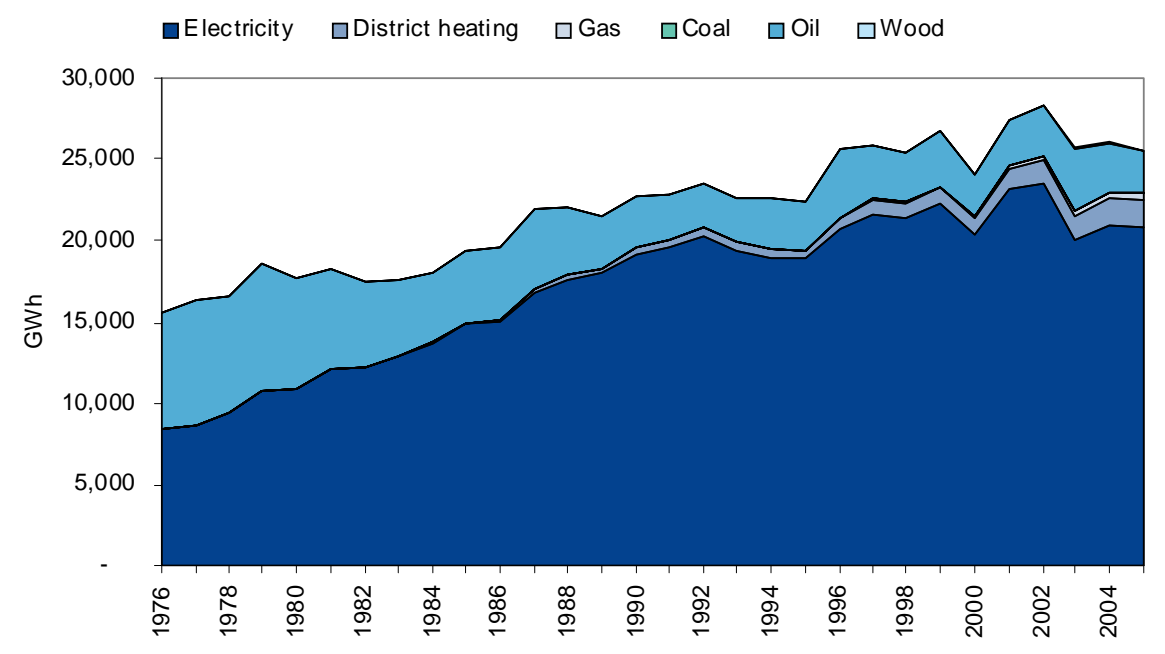

Source: Sttistics Norway and Econ Pöyry

According to figures from the so called Building network (see chapter 4), the energy consumption needed to run industrial buildings was $30 \mathrm{TWh}$, of which 83 percent was electricity, in 2006 (Enova, 2008). About 18 TWh were being used for heating. The combination of energy consumption for different purposes varied considerably between the different construction categories, and also between each building within the same category. For example, the share of energy spent on space heating summed to about 5 percent for grocery stores, while the corresponding figures for school buildings were more than 50 percent.

\subsection{Sweden}

\subsubsection{The building sector in Sweden}

In Sweden the estimated number of detached dwellings (single-family homes) was 2.0 million in 2007, whereas there were over 2.4 million apartments in multi-dwellings (Statistics Sweden, 2009a). We have no time series data for the number of square meters per household in Sweden, but the number of rooms per resident increased from 1 in 1945 to 2 in 1990. The share of overcrowded households has also declined dramatically in this period. The average floor space for a single family house in Sweden today is $152 \mathrm{~m}^{2}$, and for an apartment it is $75 \mathrm{~m}^{2}$. For new dwellings the average useful floor space in one- or two-dwellings increased from $95 \mathrm{~m}^{2}$ in 1990 to $124 \mathrm{~m}^{2}$ in 2005, whereas it declined for multidwelling units (i.e., apartments) from $75 \mathrm{~m}^{2}$ in 1990 to $67 \mathrm{~m}^{2}$ in 2005. On average each household consist of 2.1 persons. 
The household and service sector covers a total of 590 million $\mathrm{m}^{2}$ of buildings. Table 2.2 depicts the share of different types of buildings.

Table 2.2 Share of $\mathrm{m}^{2}$ for different subcategories of residential and building

\begin{tabular}{ll}
\hline Type of dwelling & Million $\mathbf{~}^{2}$ \\
\hline One and two dwelling building & 260 \\
Multi dwelling buildings & 165 \\
Premises excluding industry premises & 165 \\
\hline
\end{tabular}

Source: Statistics Sweden

\subsubsection{Energy use in Swedish buildings}

Using data from energy types used in residential and service sectors, it is clear that Swedish energy consumption follows similar relative patterns to other Nordic countries. Electricity is the largest energy source, followed by heating energy and fuels (see figure 2.12). Overall, electricity consumption has grown dramatically in Sweden since 1970, but with a declining growth rate during the 2000s, as can be seen in figure 2.13.

Figure 2.12 Type of energy source used in Residential and services, 2007, TWh

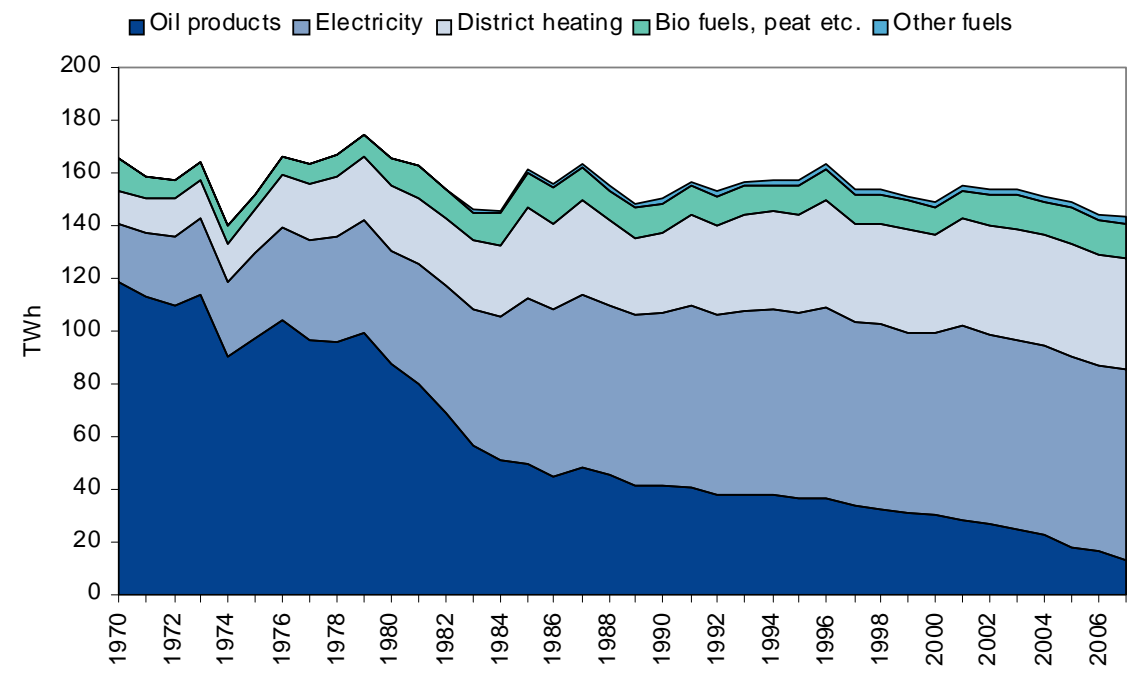

Source: Swedish Energy Agency 


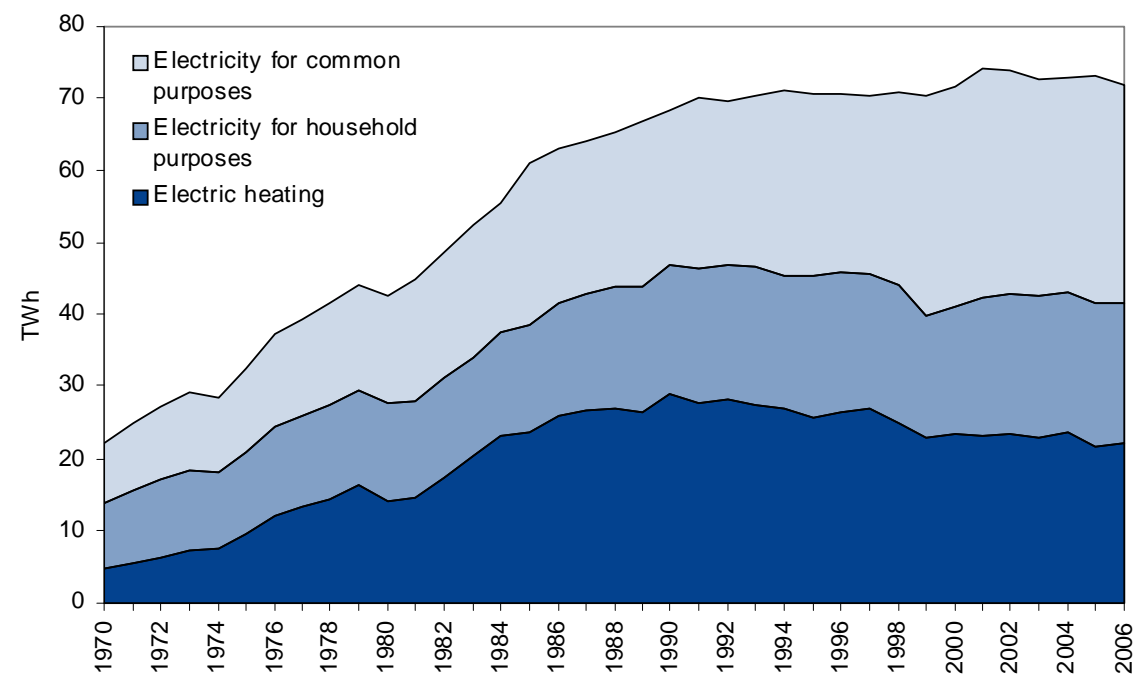

Source: Swedish Energy Agency

When it comes to total energy consumption in the residential and service sectors $^{3}$, a rather stable trend was seen from 1990 to 2001, but from 2001 it decreased (see figure 2.12). In 2005 the energy use in the residential and service sectors was 145 TWh, or 36 percent of total final energy consumption in Sweden. Nearly three-quarters of this was used by the household sector. The main reason behind this stable energy use is changes in energy carriers. During this period individual oil boilers were replaced by district heating or electrical heating. According to Statistics Sweden, district heating accounted for nearly 50 percent of the energy consumption for heating in 2005, electricity for 24 percent, biomass fuel and natural gas for 16 percent and oil for only 10 percent (see figure 2.14). When changing from oil to district heating, end-use energy losses decline, whereas energy losses in the transmission sector increase. In addition there has been a significant increase in the use of heat pumps. The use of heat pumps (mostly air-to-air) increased rapidly in recent years. In 2005 approximately 500,000 heat pumps were installed in Sweden, and one-quarter of all detached dwellings had a heat pump. Energy saving measures such as insulation and new windows have, in all likelihood, also contributed to the stability in energy consumption.

According to Statistics Sweden (2009b) the average specific heat consumption for the residential sector in Sweden in 2006 was $128 \mathrm{kWh} / \mathrm{m}^{2}$ in one- and two-dwelling buildings and $156 \mathrm{kWh} / \mathrm{m}^{2}$ in multi-dwelling buildings. The rather high figure for apartments is probably partly due to lack of individual meters (the energy cost is often included in the rent).

\footnotetext{
${ }^{3}$ These sectors include dwellings, premises excl. industrial premises, cottages, agriculture, road lighting, sewage treatment plants, power stations and water purification plants.
} 
Figure 2.14 Energy mix for heating purposes in the residential and service sectors in Sweden, 2000-2005. TWh.

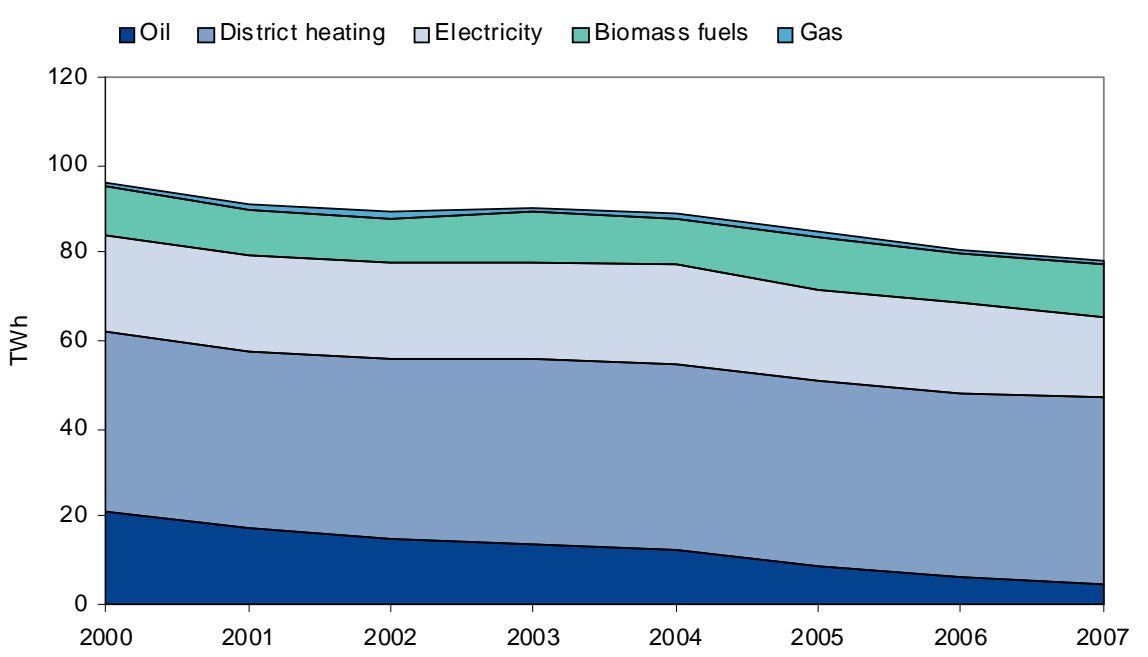

Source: Statistics Sweden, Swedish Energy Agency

\subsection{Comparing the countries}

For all countries, residential buildings (i.e., dwellings) constitute nearly 60 percent of the total building stock. In Norway over 50 percent of the dwellings are single-family houses, whereas there are more apartments (multi-dwelling) than detached dwellings in Denmark and Sweden. In table 2.3 we have gathered data on the residential buildings in the different countries for comparison.

Table 2.3 Characteristics of residential buildings in the Nordic countries

\begin{tabular}{|c|c|c|c|c|}
\hline & Denmark & Finland & Norway & Sweden \\
\hline Number of dwellings, millions & 2.5 & 1.2 & 1.44 & \\
\hline Detached & 1.1 & 1.07 & 1.1 & \\
\hline Terraced etc & 0.4 & 0.07 & & \\
\hline Multi & 1.0 & 0.06 & & \\
\hline Size, m2 & 111 & 80.5 & & 91.6 \\
\hline Detached & & & 152 & \\
\hline Terraced etc & & & 117 & \\
\hline Multi & & & 68 & \\
\hline Persons/dwelling & 2 & 2.1 & 2.3 & 2.1 \\
\hline Privately owned, \% & 48 & .. & 80 & 50 \\
\hline Number of households, million & & 2.48 & 2.2 & 4.47 \\
\hline
\end{tabular}

During the past 20 years, major differences have appeared in the energy use trends of the Nordic countries. These differences are most evident within the building sector, where the majority of energy use focuses on 
households and, to a lesser extent, the service sector. Many of these differences come from structural, geographical and policy differences between the Nordic countries. However, the trend in energy use in the household share one common characteristic in that they are all decreasing, on average. Below we discuss some reasons behind this trend.

Norway stands out as the most energy intensive country of the Nordic countries (see figure 2.15). This fact stems primarily from two facts: (1) inexpensive hydroelectricity leads to relatively low electricity costs faced by Norwegian end-users; and (2) Norway's climate can be more extreme during the cooler seasons, thus requiring greater energy use for heating. Adjusting for climate the picture becomes quite different (see figure 2.16), and the energy use per dwelling becomes much more equal between the countries.

In Denmark, Finland and Sweden district heating is the major heating source, with some variations between small dwellings and multi-dwelling buildings. In Norway district heating, so far, only constitute a marginal heating source, and electricity is by far the most common heating source.

Figure 2.15 Average energy consumption per dwelling. Ton oil equivalents per dwelling, 2000-2005.

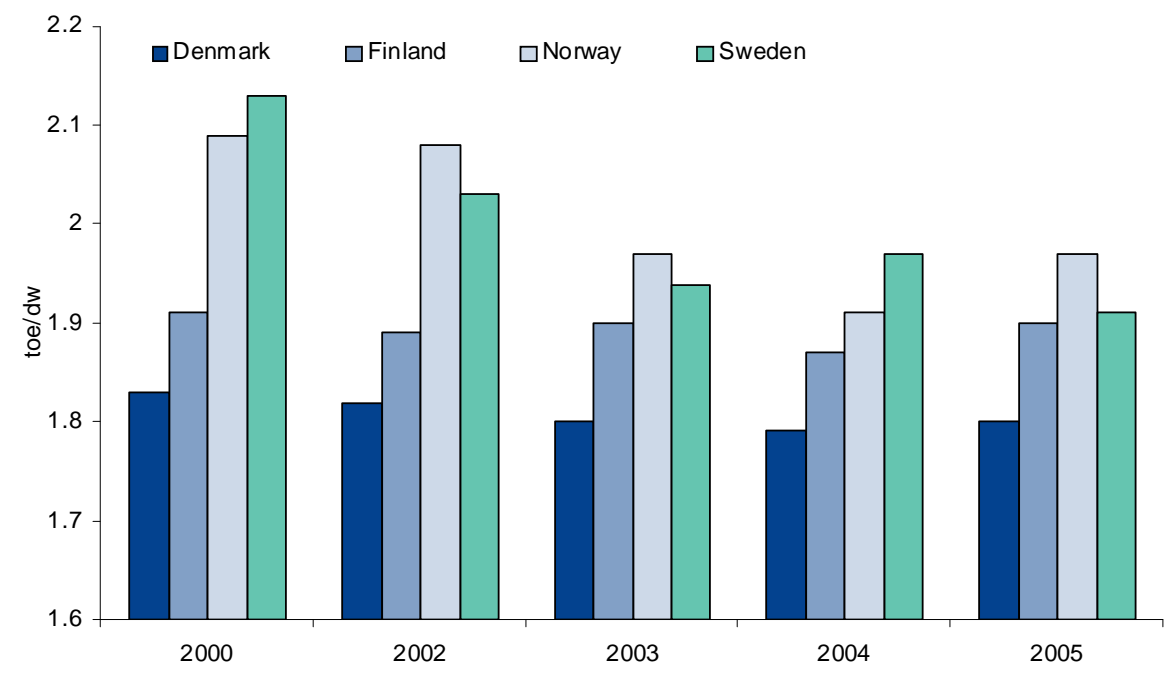


Figure 2.16 Average energy consumption per dwelling adjusted to EU average climate. Ton oil equivalents per dwelling, 2000-2005.

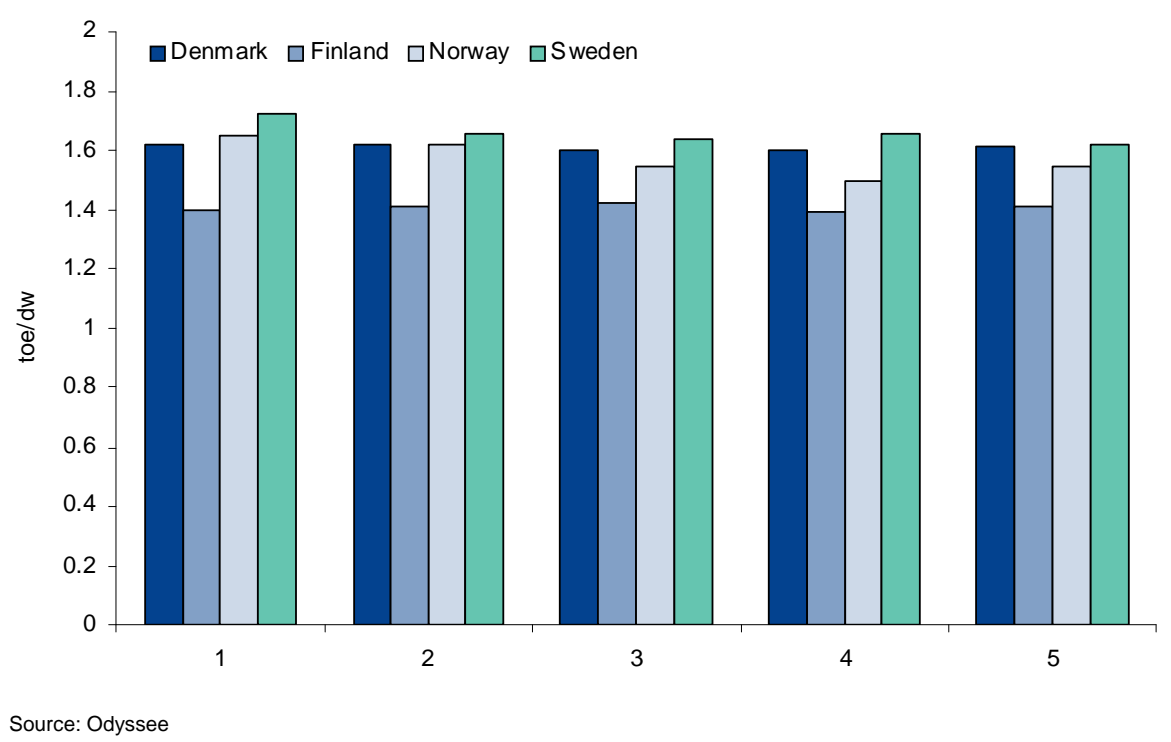

\subsection{Explanations of a flattening energy use}

The observed flattening out of energy use over the recent years has several reasons, including:

- increased energy prices;

- saturation trends;

- improved efficiency;

- climate change; and

- conversion to different energy carriers.

In the following discussion of these factors, we have focused on the effect on regular supply, i.e., energy for heating requirement, electric specific consumption, either in households or in firms. Electric specific consumption consists of, for instance, computers, household appliances and engines. The energy statistics do not distinguish between electricity used for heating and for electric specific use, and consequently, it is not possible to tell how this consumption ratio has evolved over time.

What is the impact of energy prices?

A major driver for development and composition of demand is energy prices.

Both electricity and energy are considered essential goods, used to cover the basic needs of lighting and heating. Consumption of essential goods is, by its nature, inelastic with respect to price changes. Inelastic consumption does not mean that consumption does not respond to price changes, but consumption decreases less in terms of percentages than the 
actual change in the price itself. The price elasticity size depends on time perspectives and will vary between different energy carriers. For electricity, the hourly increase in the electricity spot price will not be expected to affect the power consumption, as the consumption is not measured per hour. Per hour, this consumption will have a price elasticity of 0 . In a slightly longer time frame, for instance from one month to the next, the consumer can adapt his consumption by switching between energy carriers for heating, and reduce the absolute electricity consumption by turning off lights in empty rooms. The price elasticity will then be different from 0 , but relatively small. In a long-term perspective, the adaption will be larger, as consumers have the opportunity to invest in more efficient equipment for heating. The long-term price elasticity will be greater than the short-term elasticity, but still in the range of -1 to 0 .

Analysis of Norwegian power consumption in the evaluation of the energy law shows that the power consumption in most sectors in Norway respond to changes in spot prices, both in short- and long-term timeframes, and that Norwegian consumption, in many cases, is more price sensitive than in other Nordic countries, as discussed in Econ Pöyry (2007c). The estimates of price and income elasticises ${ }^{4}$ for power consumption in households and service industries from Econ Pöyry (2007c) are shown in table 2.4. The higher price sensitivity in Norway is explained by the fact that the spot price on the power market to a higher degree is reflected in the end-user price in Norway than in the other countries, and that the Norwegian household uses more electricity.

Table 2.4 Estimates of price and income elasticises in households and the service industry (t-value in brackets)

\begin{tabular}{lccc}
\hline & Price elasticity & Income elasticitiy & $\mathbf{R}^{2}$ \\
\hline Households & & \\
- Denmark & $-0.25(-4.5)$ & $0.58(8.8)$ & 0.90 \\
- Finland & $0.11(0.4)$ & $0.73(5.6)$ & 0.78 \\
- Norway & $-0.26(-7.1)$ & $0.36(11.1)$ & 0.90 \\
- Sweden & $-0.08(-1.1)$ & $0.27(2.5)$ & 0.48 \\
Service sector & & & \\
- Denmark & $-0.05(-1.2)$ & $0.60(18.1)$ & 0.97 \\
- Finland & $0.02(0.3)$ & $0.60(28.0)$ & 0.99 \\
- Norway & $-0.11(-1.9)$ & $0.71(13.4)$ & 0.97 \\
- Sweden & $-0.02(-0.7)$ & $0.37(5.4)$ & 0.87 \\
\hline
\end{tabular}

Source: Econ Pöyry (2007c)

\section{Saturation in future consumption?}

It is common to assume that the income elasticity for electricity, and in some cases also for other energy carriers, is less than 1 . This implies a certain flattening out in energy consumption in the sense that energy use,

\footnotetext{
${ }^{4}$ The price elasticity shows how much the demand for a certain good changes when the price of that good increases by 1 percent, the lower the elasticity (or the higher in absolute figures) the more price sensitive is the demand. The income elasticity shows how much the demand changes when the income increases with one percent, and for all normal goods and services the income elasticity is positive.
} 
in percentages, will not increase as much as the income. There are several reasons for this flattening. The most important is that energy (or what we use energy for) has the character of essential goods. With growing income, we spend a greater share of the income gain on more luxurious goods. Another reason is that most processes using energy become more energy effective over time, and shifting to new and more efficient appliances will eventually reduce the energy demand.

It is uncertain whether this strong correlation between power consumption and economic growth will continue in the future. Will, for instance, energy for heating purposes flatten out, given it is unlikely that we will heat buildings to constantly higher temperatures, even if we get richer. On the other hand, the demand for cooling may increase. For example, several new office buildings with large glass facades require extensive cooling in the hot seasons.

Income growth may also result in increased demand for electrical equipment. An example of this is the fact that the proportion of Norwegian households having access to home PCs has increased from 50 percent in 1997 to 87 percent in 2007 (Statistics Norway, 2008c).

Parts of the income growth will also result in increased consumption of services and activities outside the household, for example by increased restaurant visits. This can imply that parts of the household's energy consumption will be transferred from households to firms, primarily service sector firms.

There are thus several trends arguing for saturation in energy consumption, but there are also trends arguing against it. It is thus not possible to estimate the net effect without further analysis.

\section{Efficiency}

Energy efficiency will, all things alike, contribute to reduced energy consumption. When energy is used more effectively, it will appear to be relatively cheaper compared to other goods and inputs. This price effect will, among other things, lead to increased consumption of energy. For example, a household reducing their energy costs due to energy efficiency could spend parts or all of their gains on increasing the indoor temperature during the cooler seasons. This is known in the literature as "rebound". Efficiency gains will also give positive income effects, including increased consumption of all goods and services in the economy. All together, price and income effects may completely or partially offset the initial saving effect, and even result in increased consumption of the current resource. This effect is discussed in more detail in chapter 4.

Climate change affects demand

Average outdoor temperatures have increased since 1999, which reduces the consumption of energy for heating purposes. For instance, 2006 was the warmest year recorded for Norway since the Meteorological Institute 
started keeping measurements in 1867, whereas 2007 was the warmest year recorded in Denmark. ${ }^{5}$ According to Feilberg et al. (2007), high temperatures imply a reduction in power demand of between 1 and 2 TWh a year within Norway. It is plausible that the same holds for the other Nordic countries.

\section{Conversion of energy carriers}

Parts of the historical flattening out of energy demand can be explained by conversion of energy carriers. The total amount of fuel has been reduced due to switching from, e.g., oil and kerosene into electricity, distinct heating and gas. The conversion has been led by increased end-user oil prices, which in turn has been led by crude oil prices and taxation policy, as well as old fashioned oil heating which were not replaced by new oil heating systems when these systems are ready for replacement. This transition took place mainly in the 1970s, and can only explain a small part of the flattening out in energy consumption over the past years.

An increased use of heat pumps can however be a possible explanation, as described for Sweden above. The last years there has also been a rapid penetration of heat pumps in the Norwegian market.

${ }^{5}$ See http://met.no/Klima/Klimautvikling/Klima_siste_150_ar/Hele_landet/, and http://www.dmi.dk /dmi/index/klima/klimaet_indtil_nu/temperaturen_i_danmark.htm 


\section{Policies for increased energy efficiency - theoretical foundation}

From an economic point of view efficient energy use implies that the users are making the right choices between use and non-use (less use) of a particular piece of energy-consuming equipment and between use of that equipment and investment in a more energy-efficient version. For this to happen the energy users must face energy prices that reflect all long-run marginal costs of supply, as well as all environmental and social externalities If that is not the case, i.e., that the energy users to not face (or perceive to face) the "societal optimal" price there is a rationale for policy intervention in order to correct the actual, or perceived, price. The societal optimal price is partly driven by political targets for the energy sector and the environment.

In this chapter we start with a discussion of the rationale for policies that aim at increasing the energy efficiency, i.e., a discussion of what causes a difference between what we can call the societal right price for energy and the price the end-users actually face (or perceive to face). Thereafter we discuss how policies should be designed, from an optimal economic view, but also taking into consideration why, in practise, these policies often need adjustment.

\subsection{The rationale for policies}

The economic rationale for public intervention in a market can be regarded as different types of barriers that prevent a societal optimal behaviour. These barriers can be divided into three categories:

- market failures;

- market barriers; and

- behavioural failures. $^{6}$

Market failures encompass market inefficiencies, amongst them externalities, the existence of market power and the fact that all actors do not necessary have the same amount of information at all times. Market bar-

\footnotetext{
${ }^{6}$ Market barriers, market failures and behavioural failures are not mutually exclusive categories, and some issues/barriers may be included under any of these categories depending on the context. However, these categories are broadly useful in identifying and classifying energy efficiency barriers.
} 
riers can be thought of as restrictions, monetary or otherwise, that impede a firm or household from implementing or utilizing an energy efficiency strategy. Examples of market barriers might be the cost of installing LED lighting, patented production processes or the time cost of implementing an energy efficiency strategy. Since market barriers and market failures are addressed differently from a policy perspective, it is important to distinguish between them in the design of measures to stimulate action. Behavioural failures or barriers restrain actors from performing measures that are profitable also when market barriers have been overcome.

\subsubsection{Market failures}

Market failures occur when markets cannot deliver optimal outcomes because of inherent flaws in the market. Economic literature has explored market failures to a significant degree, and has generally identified four sources of market failure:

- externalities;

- public goods;

- market power; and

- asymmetric information.

\section{Externalities}

We talk about externalities when the private and social costs are not identical, which can be caused by, for example, air pollution or noise pollution. If social costs for energy use, for instance due to emissions in energy production, are higher than the private energy cost, energy use will be higher than what is socially optimal. If firms and individuals were faced with the true cost of energy, including the environmental costs, they would face higher prices and would thus be incentivized to reduce their energy consumption or increase their energy efficiency.

There are both negative and positive externalities. A negative externality can be pollution from a production process providing damaging effects for others. A positive externality is for example a researching activity that contributes to lifting the competence for other actors in the same field. The latter implies that firms left to themselves tends to engage less in research and development activities than what is beneficial to the society as a whole.

If energy production and energy consumption cause environmental disadvantages, the polluter should pay for the damages the society is exposed to, the externality. If the authorities could control all environmental disadvantages, and simultaneously let the polluter pay for the marginal damage inflicted upon the society, the regulation problem would have been solved. The society would face energy prices reflecting both the real economic production costs and the externalities caused by energy- con- 
sumption, and -production. As mentioned above and further discussed below, there are also other factors defending a public staking on energy effectiveness.

One of these factors is the existence of private externalities in research and development (R\&D). Due to this, private participants will under invest in $R \& D$. Hence public means aimed for $R \& D$ can contribute to a more socially optimal level of total R\&D. This argument includes all kind of technological development, and is not an argument in itself for the authorities to aim for development of environmentally friendly technologies.

Public goods

Public goods are typically defined by two properties: non-excludability and non-rivalry. Non-excludability encompasses any instance where it is impossible to prevent another person or enterprise from utilising a good. That is, public goods are available to everyone and generally on an equal opportunity basis. Non-rivalry means that one individual's usage of a public good does not necessarily disrupt or completely negate the benefits enjoyed by other users. Regarding energy efficiency measures, public goods are most likely not a relevant barrier.

\section{Market power}

Markets function most efficiently when the competitive environment between firms is strong. If certain firms have significant market power, such as an exclusive technological/patent or area based monopoly, there may be little pressure for these firms to adopt energy efficient strategies. A converse example is that the energy users may be faced with monopoly providers of energy, who are inefficient providers or who may refuse to implement energy saving measures, such as digital energy meters or efficiency promoting pricing schedules.

Asymmetric information

Incomplete information is any information that is either incorrect or unknown by a decision making entity. This failure can take many forms. If a firm or an individual does not know about the existence of certain energy saving technologies or programmes, then an incomplete information failure has occurred. Unknown or inaccurate cost/benefit information is another example which distorts decisions. A further exploration of incomplete information might include diverging incentive structures, such as tenants demanding cheaper rental rates versus landlords' energy efficiency property investments (e.g., single- versus double-glazed windows). While there are many other examples of incomplete information as a barrier to energy efficiency, the general idea is fairly simple. On the other hand having limited information about energy efficiency possibilities is not necessarily a result of market failure. Seeking and gaining in- 
formation is a costly activity, and for the individual actor seeking more information might be perceived as being more costly than the potential profit from acting on it.

\subsubsection{Market barriers}

The prime example of a market barrier is cost, both upfront monetary costs, and unknown hidden costs. Upfront monetary costs can easily be incorporated into energy efficiency strategies, and be assessed fully through cost-benefit analyses to ensure an appropriate decision is made. For example, using appropriate discount rates, energy savings over time can be calculated and compared with the fixed and variable costs throughout the implementation and payback period. The implementation time period is especially important, as some energy efficiency measures have extremely high fixed costs, such as the installation of solar panels which have a relatively long payback period.

Households and small firms often have very short time horizons, demanding short payback periods, for instance only 2 years, for energy efficiency investments. A two-year payback period implies an annual discount rate of over 41 percent, which is considerably higher than many economic and financial models assume for energy efficiency analyses. The rationale behind this discrepancy can be found in managing uncertainty. In comparison to larger firms, small and medium sized companies may be either less convinced that energy saving measures are worthwhile or believe that they might be more highly exposed to market volatility and thus more concerned with short term capital requirements.

Hidden costs are often easily understood, but can be difficult to identify ex-ante. Their existence can drive uncertainty within the decision making process and create additional barriers, such as a larger risk premium which effectively increases the discount rate. Hidden costs can take numerous forms, including:

- implementation time/business disruption;

- staff education;

- equipment compatibility; or

- auditing costs for regulatory compliance.

\subsubsection{Behavioural barriers}

For many actors in the building sector total energy costs are a relatively small portion of their total costs and this in itself may explain a relative lack of zeal to adopt energy efficient technologies and behaviours. Without the promise of significant cost savings there is insufficient incentive to merit a focus on energy and its productive use. Thus, for many, tackling energy efficiency is a low priority task compared with the manage- 
ment of other more significant input costs. This concept is typically described as bounded rationality, which describes the limitations of an individual to explore all opportunities equally without any restrictions.

Inertia is another significant behavioural barrier, whereby entities require more incentives to motivate a change in behaviour or attitude than theoretical economics predict. This occurs when long-standing practices are confronted with new methods, which are often perceived by those required to implement them as either unproven or unnecessary.

Risk aversion or loss aversion can also severely limit the uptake of energy efficiency technologies and behaviours. Risk aversion can distort the true cost-benefit analysis, causing actors to choose sub-optimal strategies because they are willing to pay a premium to ensure a lower risk of loss. Thus, some energy efficiency technologies might require extremely strong evidence of very high benefits to persuade some individuals to invest a relatively small sum.

\subsubsection{Special barriers in the building sector}

Energy consumption has so far been less stressed in construction and rehabilitation of buildings and housing. There is more than one reason why energy consumption has had low priority, e.g., short-term assessments focusing on low costs in the construction phase, lack of knowledge, fragmented businesses, many decision makers, organisational barriers and low energy prices.

The GMCT report points to several characteristics of the building sector that are significant for the sector's innovation capacity (Emtairah et al., 2008). The same characteristics can also explain the barriers for energy efficiency in the sector, see for example Econ Pöyry (2007a) and Bellona and Siemens (2007a). The most important characteristics are:

- There are many actors with different priorities and interests, for example project based organisation in the construction phase (each construction project is unique), but process based organisation in production of construction materials (stronger elements of mass production). In addition many of the actors are small and mediumsized companies, especially on the local and regional levels.

- Cyclically sensitive sectors, with large variations in the activity level in depressions and booms respectively, contributes to less focus on long-term strategies, and to a lack of resources that could have been used in developing and using innovations.

- An open labour intensive sector, with large mobility in the labour force, especially specialists, such as local entrepreneurs in the regions can experience problems attracting qualified employees.. 
- Unbalanced distribution of technological risk and financial profit. The potential financial profit moves up to the final consumer, while the risk of mistakes moves downward in the value chain.

- Expensive products with long duration, witch means they want to reduce the risk and ensure the economy by using standard solutions and models that historically have been successful.

Several of the above-mentioned barriers are mutually dependent and will contribute to strengthen each other. High capacity utilization means, for example, that competence building is not a priority. Most factors point out a business with low innovation capacity confirmed by low R\&D effort at a company level.

Different incentives for builders, owners and users

Another important barrier for increased energy efficiency in the building sector is linked to the ownership and use structure. Very often the building construction firm, the owner and the user of the building are not the same entity, and the incentive to save energy differs between these, see SOU (2008a) and OECD/IEA (2007). The builder or owner has an incentive to limit the investment costs when building or renovating, and might thus not install the most efficient systems or equipment, assuming that these systems are more expensive than standard systems. The user on the other hand should have an incentive to demand more efficient systems, since it normally is the user who pays the energy bill. But the user is often not a part in the building process, and hence has small opportunities to impact the building process. As mentioned above, the users are subject to the same kind of market and behavioural barriers above, and might therefore not even demand more energy efficient buildings. According to OECD/IEA (2007) the energy use per square meter is 20 percent higher in leased office space than in owner occupied office space in Norway. Since the first group constitute about 80 percent of total office space in Norway there is a substantial potential for reduced energy use by reducing the split incentive barrier, amounting to 15 percent of total energy use in the commercial office sector.

\subsection{The design of measures}

The discussions above show that there are several rationales for the authorities to design and implement measures in order to affect individuals and companies behaviour regarding energy use and savings. Before looking at what policies and measures are actually being used we shortly describe some relevant issues regarding the design of policies and measures. The discussion is mainly focus on measures to internalise negative exter- 
nalities, but several of the discussed aspects also holds for other rationales (like energy security and R\&D of energy efficient technologies).

\subsubsection{The ideal approach}

As a general requirement, public policies should be cost-effective, in the first instance, in reaching the target at acceptable cost (cost effective) and, secondly also in ensuring that the target is actually reached, i.e., that the actual savings are realised (steering effective). Cost efficiency requires that the decision to implement energy savings measures is left to the individual enterprises. This allows market considerations to determine optimal energy efficiency decisions, and favours the allocation of resources to the most marginally productive activity or technology. In general, this type of equilibrium occurs when marginal cost equals marginal benefit, and from a policy perspective it points to the importance of accurately gauging both costs and benefits.

The so-called first-best solution ${ }^{7}$ to a problem is to regulate it as close to the source as possible. The reason behind this statement is the fact that the closer to the actual problem the regulation is imposed, the more actors are affected by the measure and can respond to it. The measures thereby become more accurate. Very often it is the emissions, or other environmental impacts, that are the source of the environmental problems, not the energy use itself. The best solution is then to regulate the emissions, and not the use of energy that causes the emissions.

Environmental problems (like climate changes and air pollution) can be regulated by several different kinds of measures, among them taxes, regulations of maximum allowed amounts of emissions and total bans. From a cost-effective perspective, taxes are to be preferred before direct regulations. The reason is that, in addition to motivate abatement of the emitter's externality, the price of the product will usually rise. This gives consumers of the goods an incentive to reduce their use as well. Direct regulations will not give the same price incentive to other actors but might be more accurate when there is an uncertainty about how to set the appropriate tax. In the case of severe damages and/or uncertain impacts of taxes, a ban might be the most effective measure in reaching an environmental target.

Taxes are a way to internalise environmental externalities: if the social cost of a polluting activity is larger than the private cost, the pollution shuld be taxed in order to make the private cost equal to the social cost. If a tax is levied on an emission stemming from the production or use of energy the following will happen.

\footnotetext{
${ }^{7}$ This is the solution that, theoretically, would give the most cost-effective solution, that is most benefit in relation to resources spent on the solution.
} 
- More efficient use of energy, both by the producer, who will respond partly by reducing the demand for the input factor that causes the emissions, and at the consumer of the energy service since this service is most likely to become more expensive.

- Substitution towards less harmful energy sources and/or production technologies with smaller, or no emissions of the taxed emission.

- Abatement of the emissions as long as the abatement costs per unit of emission is lower than the tax per unit.

If a tax is levied on the energy source, instead, it will only induce the two first effects, provided that the tax is adjusted in accordance with the (supposed) emissions. If this should not hold, i.e., non-differentiation of the tax, only the first effect would occur. A direct regulation in the form of maximum allowed emission would also induce more efficient use, substitution and abatement. The difference in relation to the tax is that the regulation gives no, or at least smaller, incentives to efficiency increase at the consumer level. This is due to that the producers do not have to pay for the remaining emission, and thereby the price of the energy service will not be affected to the same degree as in the tax alternative.

Regulate, and let the market decide how...

When the authorities use the price mechanism through taxes they avoid favouring specific technologies, but leave the market to decide how to react to different regulations. It is thus important to stress that a costeffective measure is not equal to a desire to impose an end-of-pipe solution instead of a desire to change consumption patterns of energy or other resource-intensive commodities. The crux of the matter is that it leaves the polluter to decide how to respond. Provided that there are no large inefficiencies in the markets, the polluter and other actors will choose the most cost-effective mix of abatement, substitution and reduced material (included energy) intensity.

\subsubsection{Shortcomings of the idealised approach}

Often the preconditions underlying the "first best" recommendations in the previous section do not hold in practice. When the first best option is not available, the authorities must seek a second (or next) best solution. Below we discuss the most important reasons why, in practice, the next best option is often chosen, thus necessitating different regulation.

\section{Conflicting targets}

There may be several limitations for using the price system for changing the way energy is produced and consumed. Conflicting targets may be an important obstacle to using the price mechanism. Several countries have targets regarding energy prices, stating that the end-use prices should be 
"reasonable". Increased taxes on energy (or energy related emissions) might conflict with that target. Increased energy prices might also be difficult to "sell" to the public (end-users), regardless of political targets. Other measures may distribute the costs of the policy differently, or disguise the costs, so that they become more politically palatible than carbon-based energy taxes.

Environmental policies can also be in conflict with other policy aims, such as employment and regional policy. Strict policies might, at least in the short run, induce large adjustment costs.

\section{Transaction costs and other barriers}

In order to regulate emissions the authorities usually have to handle (and have access to) a lot of information, and ensure regulations are followed. For some pollution it may be less appropriate to regulate the actual emission, due to large control and information costs. This is typically the case when the emissions stem from many small or diffused sources.

Market and behavioural barriers might also not be properly addressed by the price system, at least not in the short run. For instance, one important barrier in the building sector is the way new constructions are being organised, with several independent actors, which will not likely be affected by energy taxes. In addition, in the case where the builder/owner and user is not the same person er legal entity, the price signal, who affects the end-user is not always "properly" dispersed to the builder and/or owner.

\section{Uncertainty}

Uncertainty about impacts, especially in the long run is a reason for deviating from the general recommendation of environmental taxation. For instance, a ban on emissions that are likely to cause severe or irreversible damages might be more appropriate than a tax on the actual emission.

There will always exist uncertainty regarding the valuation of the damages from different emissions, which spills over into uncertainty about the proper dosage of the tax.

\section{Leakage}

There will always be some risk that measures aimed toward internalizing pollution externalities may lead to leakage, i.e., production, and thereby emissions, move abroad. In the case of $\mathrm{CO}_{2}$ and other GHG, the result may thus be unchanged emissions from a global perspective, but an economic cost (i.e., lower production) for the country in question. This might explain some of the political unwillingness to use the price mechanism when designing measures. The industry often claims that taxes will reduce their competitiveness as long as other countries (trade partners) do not do the same. This argument calls for international agreement. 
The risk of leakage might be a legitimate argument for emissions that are impossible or hard to abate. How important the problem actually is, or will be, is an empirical question. For the building sector this argument is probably not very strong, since this is largely an immobile sector.

Equity

Policy measures will generally have two conflicting aims: efficiency versus equity. It is often the case that the most efficient policy is highly inequitable whilst the equitable policy would introduce into the economy significant distortions and disincentives. Energy is a basic good, and is for instance used to fill basic needs like heating. Higher energy prices are likely to affect poorer households relatively hard since they often have fewer possibilities to save energy.

The most appropriate answer to this conflict is to regard equity and environmental protection as two different goals, which should be handled with different measures. To achieve a certain number of objectives the government needs at least the same number of policy measures.

\subsubsection{Second best policies and measures}

As seen above there are several reasons why pragmatic policies often must deviate from the theoretical recommendations. This means that policy-making often is about finding the right second best solution to a problem. A second best approach might involve policies targeted directly towards energy efficiency. Examples of such policies are (the policies are further described in chapter 4):

- Information campaigns, aiming to overcome informational barriers

- Support to energy conservation measures, which might overcome barriers related to actors being financially restrained, for instance that they are unable to raise a loan. Governmental support to such investments can be a way of overcoming this inefficiency. The support can be given either as investment subsidies or as so called soft loans ${ }^{8}$.

- Financial support to $R \& D$ to energy efficiency projects, and environmentally benign energy sources and technologies.

- Technical standards that firms and individuals must obey.

- Agreements between the authorities and the industry (either single actors or branches) where the authorities specify the target, whilst the industry decide how to reach this target.

\footnotetext{
${ }^{8}$ Loans with a lower interest rate than the market rate and/or with more favourable lending terms.
} 


\subsubsection{Social cost of promoting energy efficiency}

Most of the above listed energy conservation policies have some kind of drawback that represents a cost for the society. Some of the costs these measures can incur, apart from the budgetary cost for the authorities, are:

- Rebound or counteractive adjustment. More energy-efficient equipment will reduce the marginal cost for the consumer of obtaining the service produced by the energy-using equipment. Energy hence becomes cheaper. Producers and consumers can respond to this energy cost reduction by actually increasing the demand for energy, if demand is sufficiently price-elastic. Rebound is further discussed in chapter 5.

- Cost of complying with standards. Standards are sometimes said to be "cheap" since they do not in imply government outlays or tax revenues. But nevertheless, they incur costs for society since the private actors subject to the regulations must invest in new equipment earlier than they otherwise would have done.

- Risk of lock-in. The risk of focusing support on a specific technology is that one might overlook other sources or technologies that actually could have proven better. The society thereby runs the risk of being locked-in with an inferior technology. This argument calls for measures that are neutral with regard to technology choices.

- Free-riders and additionality. Free riders are users that benefit form energy efficiency policy measures, but who would have carried out the measure even without the policy. In principle support should only be given to investments that otherwise would not have been performed, i.e., the support should be additional. Interpreting the additionality requirement very strictly means that only investments that are unprofitable with given market prices should be supported. But if one acknowledges other barriers, like information failures, support to profitable technologies can be justified and not regarded as a free rider. One solution to the free rider problem is to design programmes that avoid providing tax relief for technologies that are already profitable, but, as this generally requires more administration, these programmes tend to be more expensive than technology neutral programmes. In most cases there is a trade off between the risk of free riders and the administrative cost of the programme.

- Interplay with other resources. Focusing on one resource may have unintended side effects. In an economy the use of all resources (labour, physical capital, energy, and materials) are interconnected. Measures intended to affect one resource (or input factor) will in the end affect all, through readjustment processes in production and consumption. The side effects regarding use of other factors, such as labour and other natural resources, from energy efficiency measures are often hard to predict. A strong emphasis on increased energy 
efficiency might speed up the rate of technological development and reduce the lifetime for energy using equipment. A shorter turnover for electrical equipment will increase the use of materials, and the demand for waste handling options (recycling, incineration and landfills). Recycling might be a way to partly overcome this, both in a material-saving perspective and due to the fact that production based recycled materials often require less energy than production based on virgin materials. But recycling also demands resources in collection, cleaning and sorting and is by no means a no cost option.

- Risk of creating new market distortions: It is also important to recognise that policies targeting certain industries or sub-sectors can create market distortions. For example, increasing the energy efficiency incentives for the building sector might lead to greater capital investment in this sector rather than to other, more marginally productive investments in other sectors. As a basis for "good" public policy, all energy efficiency promoting initiatives should be available on an equal opportunity basis to all market participants or sectors.

Before implementing new measures, or adjusting existing measures it is recommended that cost-benefit studies accounting for these factors be undertaken. Such cost-benefit analyses should assure that the potential benefits of the measure are larger than the total costs - also taking into consideration the administrative cost at the levels of the implementing agency and the enterprise. 


\section{Policies for energy efficiency in the Nordic countries}

Most countries have a set of energy efficiency policies, including both generic instruments (i.e., affecting more or less all energy users) and instruments targeted towards certain sectors. There exist several different types of policies, which, to aid in the further discussion, can be divided into three groups: fiscal incentives, regulations, and informational/management assistance.

The main concerns connected with the use of energy are the risk of climate changes, pollution, energy scarcity, and geo-political conflict due to location of energy resources. These are all more or less complex problems, and they are often interconnected with each other. In order to handle these problems it might be appropriate to strive towards increased energy efficiency, including both the way energy is produced and used.

In this chapter we take a closer look at what policies and instruments in use within the Nordic countries in order to increase energy efficiency in general and in the building sector in particular. For a more detailed description of measures used in the Nordic countries see appendix I-IV.

\subsection{Underlying policies}

\subsubsection{EUs targets for energy efficiency}

Many energy policy measures and targets in the Nordic countries are grounded in policies and targets set by the European Union. Therefore, before examining, in detail, policies and targets in the Nordic countries, we start with a short description of relevant EU objectives and targets.

In its various policy documents, the European Commission refers to three key objectives for the EU energy policy: sustainability (including a reduction of energy demand), competitiveness and security of supply. Greater energy efficiency is key to achieve these three objectives in all countries.

EU energy policy objectives are formulated as part of the wider EU “climate objectives”. In Spring 2007, EU Heads of State and Government agreed a so-called "20 2020 by 2020" policy objective, including a reduction of $\mathrm{CO}_{2}$ emissions by 20 percent by 2020, an increase of the share of renewable energy to 20 percent by 2020 and an improvement by 20 percent in energy efficiency by 2020. For the latter target, the European Council "stressed the need to increase energy efficiency in the EU so as 
to achieve the objective of saving 20 percent of the EU's energy consumption compared to projections for 2020, as estimated by the Commission in its Green Paper on Energy Efficiency, and to make good use of their National Energy Efficiency Action Plans for this purpose”.

In December 2008, the EU institutions agreed the final version of the legal instruments ${ }^{9}$ supporting the "climate change" package. This package does not include any new legally binding targets for energy efficiency, but the existence of legally binding targets for renewables and $\mathrm{CO}_{2}$ emissions are direct incentives to also achieve the target of an improvement of energy efficiency by 20 percent by 2020 .

Moreover, four different tools exist at EU level to increase energy efficiency:

- The EU action plan for energy efficiency (Commission's proposal COM (2006) 545 "Action Plan for Energy Efficiency: Realising the Potential” - and Council conclusions of November 2006), listing a set of priority actions and requiring Member States to report on progress

- The Directive on energy end-use efficiency and energy services (2006/32/EC). According to this Directive, each Member State should reduce its final energy consumption by at least 9 percent by 2016 compared to the average final energy consumption during the period 2001 to 2005. This target shall be reached using national methods, of which some originate from EU law. Companies which are part of the EU-ETS system are not included in this target. Each member country should also formalise a milestone for 2010.

- The Directive for EU Energy Performance of Buildings - EPBD (Directive 2002/91/EC), which is the main Directive for energy use and savings in the building sector. This Directive, and how it is being implemented in the countries under review, is discussed below.

- The co-funding of projects by the European Union, as part of the EU cohesion and regional structural funds for 2007-2013.

\subsubsection{Denmark}

The political agreement on energy made in February 2008 between the government and most of the parties seated in Folketinget lays down the current policy targets and measures for the period of 2008-2011. The overall rationale as stated in the agreement is to reduce the country's dependency on fossil fuels.

\footnotetext{
${ }^{9}$ Directive on renewables (RES directive), Directive on fuel quality (FQD directive), Regulation on $\mathrm{CO} 2$ from cars (CO2 directive), Directive on the storage of $\mathrm{CO}_{2}$ (CCS directive), Decision on effort sharing (for sectors outside ETS), and Regulation revising EU ETS.
} 
In the energy statement (Energiredegørelse) by the government in the Danish parliament in 2008, the rationale of current energy policies of the government is stated to be the combination of reducing dependency on fossil fuel, mitigate climate change and reduce costs to the society. According to the most recent government action plan on energy savings (from 2005), energy savings are believed to contribute to growth and development of the economy, to promote security of supply and to mitigate climate change. A decision criteria for pursuing energy saving potentials by governmental measures is that they should be cost-effective to the society as presented in the 2005 Action Plan on energy savings.

The political agreement of February 2008 establishes quantitative targets for reducing demand for primary energy sources and for reducing end-use energy consumption. With regard to end use, the target is annual savings corresponding to 1.5 percent of the demand by end-users in 2006. This equals annual savings at $10.3 \mathrm{PJ}$ and is beyond the Member State target stipulated in the Directive of the European Commission. The target is defined as annual new savings (first year savings).

\subsubsection{Finland}

The Finnish energy policy has three overarching principles: energy, economy and environment. Supply, competitive energy prices and the reduction of harmful emissions to comply with international obligations is important. ${ }^{10}$

Finland has reported measures put in place to comply with the EU directive on energy efficiency and energy services. Finland has chosen the same level of ambition as the directive stipulates, i.e., final energy consumption at least 9 percent lower by 2016 compared to the average final energy consumption during the period 2001 to 2005.

Finland has a climate strategy from 2001, which was revised in 2005 for short-term perspective and in 2008 for long-term perspective. The strategy has had the intention to reduce greenhouse gas emissions, promote growth and employment and competitiveness internationally, securing energy, diversify energy sources and improve energy efficiency and renewable energy. ${ }^{11}$ The energy and climate strategy covers climate and energy policy measures in detail up to year 2020, and in brief thereafter up to 2050. The 2008 strategy includes outline for energy and climate policy and proposals for key measures for the attainment of objectives.

The objectives for total final use of energy are, according to the strategy, 310 TWh by 2020 and for electricity consumption and 98 TWh by 2020 (consumption levels 2005 are 392 TWh and 90 TWh respectively). This would mean, compared to the baseline, a 12 percent reduction in

\footnotetext{
${ }^{10}$ See the Ministry of Employment and the Economy (www.tem.fi) which is responsible for energy policy and implementation of EU energy directives.

${ }^{11}$ Government Report to Parliament 6 November 2008 (2008) Long-term Climate and Energy Strategy http://www.tem.fi/index.phtml?l=en\&s=2542
} 
total final energy consumption and 5 percent in electricity consumption. The combined target for residential, electricity heating and service sectors is $6 \mathrm{TWh}$, or a 14 percent reduction in total electricity usage compared to 2020 baseline.

There is a section covering buildings and construction in the climate and energy strategy which includes a target of reducing the total energy consumption in new buildings by 30 percent by 2010 compared to current regulation level. Second stage of reducing energy consumption will be an additional reduction by 20 percent. Energy efficiency will be promoted also in renovation of existing buildings by tax deductions and energy subsidies. According to the strategy, Finland wants to continue and expand the voluntary agreements (see below) between authorities and the private and public sectors. The goal is that 90 percent of end-use within the sectors that are liable for voluntary agreements should be covered by these agreements, against 60 percent today.

\subsubsection{Norway}

The Norwegian energy policy consist of 4 main targets, or areas: a strong public ownership in the sector, security of supply, environmental issues including the climate challenge and efficient energy use. For our purpose the three main energy political challenges are related to a tight power balance (security of supply), the climate policy and the adaptation to the EU directive for renewable energy. Both production and consumption of energy and power plays a major role in the climate change solution. In January 2008, the majority of Norway's political parties reached agreement on a number of major steps for reducing emissions, the so called Klimaforliket. As part of a global and ambitious climate agreement where other industrialised countries also take on large obligations the main long term target for Norway is to become carbon neutral by 2030, i.e., all emissions in Norway are to be offset by emission reductions elsewhere. In the shorter run, Norway will undertake to reduce global greenhouse gas emissions by the equivalent of $30 \%$ of its own 1990 emissions by 2020. The Government considers that a realistic target is that about twothirds of Norway's total emission reductions are to be achieved in Norway. Taxes and emission trading will remain the most common measure to realise the target, but Klimaforliket also includes provisions for Norway to channel more resources into renewable energy, environmental research and the development of new technologies.

Norway has no explicit target for increased energy efficiency, but an overall target to realise 30 TWh new renewable energy and energy savings between 2001 and 2016. It is the state company Enova that is responsible for measures to achieve this target. 


\subsubsection{Sweden}

Energy, in combination with climate change issues, is regarded as one of the most important challenges in the Swedish energy policy. The objective of the energy policy is safe and environmentally friendly energy supply and reasonable energy prices. The policy should contribute to an efficient and sustainable use of energy. Environment and energy taxes shall be constructed to create incentives for taking environmental aspects into consideration.

The Swedish part of the EG Directive means that Sweden must fulfil saving through energy efficiency methods of 41.1 TWh in primary energy which corresponds to 32.2 TWH in final consumption by 2016. In addition to EU-targets, the Swedish Parliament has agreed on a national target. This target means that the total energy consumption per heated area unit in buildings and premises should be reduced by 20 percent by 2020 and 50 percent by 2050, with 1995 as a base year.

The Swedish government has furthermore put in place a number of instruments and working groups that continuously will work towards a more energy efficient consumption. Some instruments are more general, such as the carbon and energy tax and some more targeted, such as conversion support schemes.

Overall, it is the Swedish Energy Agency (Energimyndigheten) that has the responsibilities for any energy efficient activities covering the housing-, service, and industry sections. Furthermore, the Energy Efficiency Study (SOU 2008b) has given the Swedish Energy Agency the mandate to review the requirements in terms of energy efficiency in the law, responsibility for programmes for energy efficiency in energy intensive industry as well as in the Environmental Code (Miljöbalken). However, it is the National Board of Housing, Building and Planning (Boverket) that is the administrator of many measures aimed toward energy efficiency.

\subsection{Instruments being used}

In this section we shortly describe instruments that have been, and are in use in the Nordic countries in order to enhance energy efficiency, with focus on the building sector. We have focused on national instruments, but also describe some local instruments being used in individual counties or municipalities. 


\subsubsection{Fiscal incentives}

Economic actors, be it private households or enterprises, are often incentivized through direct or indirect financial benefits arising from fiscal incentives. Many of these incentives are tax based, either levying a tax on unwanted behaviour (internalising negative externalities) or abating tax on positive behaviour. Direct transfers are another fiscal incentive, which can yield immediate or over-time payments to entities meeting certain criteria. Direct transfers can take the form of government funds to defray upfront implementation costs or subsidies.

Taxes and charges

From an economic point of view, energy taxes are the optimal policy to internalise the external costs from energy use, but in many cases this is not a viable policy, for instance, based on competitiveness. In these cases, giving subsidies to entities not causing these external effects can be a next best solution

Energy or carbon taxes that give an economic incentive to reduce energy use is being used in all the Nordic countries, where table 4.1 summarizes the main taxes affecting stationary energy use. The purpose of these taxes can be both fiscal (generating tax revenues) and to internalise external effects from energy use, mainly environmental costs. An assessment of the Swedish energy efficiency policies shows that energy taxes have lead to significant energy savings (SOU, 2008b).

Sweden has a system of obligatory green certificates to promote renewable power production, which affects the end-user electricity price and hence can be regarded as a form of tax. In 2007 the end-users paid on average $0.04 \mathrm{sek} / \mathrm{kWh}$ (including VAT) for these certificates (Swedish Energy Agency, 2008). 
Table 4.1 Taxes on stationary energy use in the Nordic countries

\begin{tabular}{|c|c|c|}
\hline Country & Type of Tax & Size \\
\hline \multirow[t]{4}{*}{ Denmark1 } & $\begin{array}{l}\text { Energy tax on fossil fuel consumptions, } \\
\text { except for consumptions applied for electricity } \\
\text { generation. }\end{array}$ & Vary per fuel \\
\hline & Energy tax on electricity consumption & $\begin{array}{l}0.55 \mathrm{DKK} / \mathrm{kWh} \text { (for electricity con- } \\
\text { sumption above } 4000 \mathrm{kWh} / \text { per year } \\
\text { for residential heating, the tax is } \\
\text { lower). }\end{array}$ \\
\hline & $\begin{array}{l}\text { CO2 tax on fossil fuel consumption except for } \\
\text { consumptions applied for electricity generati- } \\
\text { on. }\end{array}$ & $\begin{array}{l}62-92 \text { DKK/t CO2 on fuels for com- } \\
\text { fort heating. Will be increased to } 150 \\
\text { pending approval by the European } \\
\text { Commission. }\end{array}$ \\
\hline & $\mathrm{CO} 2$ tax on electricity consumption & $0.899 \mathrm{DKK} / \mathrm{kWh}$ \\
\hline \multirow[t]{4}{*}{ Finland } & $\begin{array}{l}\text { Basic tax on fossil fuels, staggered in accor- } \\
\text { dance with their grade and environmental } \\
\text { characteristics }\end{array}$ & Light oil $0.0294 € / I T a l l$ oil $0.067 € / l$ \\
\hline & $\begin{array}{l}\text { Additional tax and security of supply fee on } \\
\text { fossil fuels }\end{array}$ & $\begin{array}{l}\text { Light oil } 0.0541 € / \mathrm{lHeavy} \text { fuel } 0.0642 \\
€ / \mathrm{kg} \text { Coal } 49.32 € / \mathrm{t} \text { Natural gas } 2.016 \\
€ / \mathrm{MWh}\end{array}$ \\
\hline & Additional tax on electricity, industrial & $0.0035 € / \mathrm{kWh}$ \\
\hline & Additional tax on electricity, consumers & $0.0087 € / k W h$ \\
\hline \multirow[t]{4}{*}{ Norway } & Electricity tax, households, services & $0.1023 \mathrm{NOK} / \mathrm{kWh}$ \\
\hline & Electricity tax, industry & $0.0045 \mathrm{NOK} / \mathrm{kWh}$ \\
\hline & General mineral oil tax (light fuel oil) & $0.106 \mathrm{NOK} / \mathrm{kWh}$ \\
\hline & CO2 tax, light fuel oil & $0.069 \mathrm{NOK} / \mathrm{kWh}$ \\
\hline \multirow[t]{6}{*}{ Sweden } & Carbon tax, services and households, & $\begin{array}{l}1.01 \mathrm{SEK} / \mathrm{kg} \text { CO2 (equals } 0.3617 \\
\text { SEK/kWh for light fuel oil) }\end{array}$ \\
\hline & $\begin{array}{l}\text { Activities within EU-ETS: Industry and district } \\
\text { heating }\end{array}$ & $0.07-0.15 \mathrm{SEK} / \mathrm{kg} \mathrm{CO} 2$ \\
\hline & $\begin{array}{l}\text { Activities within EU-ETS: additional heating } \\
\text { plants }\end{array}$ & $0.86-0.94 \mathrm{SEK} / \mathrm{kg}$ CO2 \\
\hline & Electricity tax, general rate & $0.27 \mathrm{SEK} / \mathrm{kWh}$ \\
\hline & $\begin{array}{l}\text { Electricity tax, reduced rate (northern munici- } \\
\text { palities) }\end{array}$ & $0.178 \mathrm{SEK} / \mathrm{kWh}$ \\
\hline & General tax on heating oil (light fuel oil) & $0.0959 \mathrm{SEK} / \mathrm{kWh}$ \\
\hline
\end{tabular}

${ }^{1}$ Denmark: The energy taxes on electricity and fossil fuels apply to all consumptions for comfort heating purposes in residential, public \& service sectors as well as in industry.

Subsidies

As already mentioned, subsidies are used to promote investments or actions that are supposed to be beneficial to society, and are often used in circumstances where taxes on unwanted activity is not viable.

At present, external effects, such as greenhouse gas emission, are probably the main argument behind subsidies for investments in increased energy efficiency. Many countries also apply such subsidies, like direct investment support or tax deductions for energy efficiency investments.

In Norway investment subsidies are the main measure used to promote both increased energy efficiency and renewable energy. These subsidies 
are administered by Enova, a state owned company. Amongst Enova's programmes is one that targets the building sector, called "Energy use buildings, houses and premises". This programme should contribute to sustained improvement with the sectors buildings, houses and premises. Both current and new buildings can apply for support of approx 0.2 to 0.5 $\mathrm{NOK} / \mathrm{kWh}$ reduced energy use and/or produced heating from renewable energy annually.

From 1997 to 2007 Sweden had a investment subsidy programme with the Local Investment Programme (LIP), which aimed at reduce pollution to air and water. Energy efficiency was hence an indirect effect of the programme and it is estimated that the programme will lead to 0.23 TWh/year savings up to 2016 if continued. A related programme is the ongoing Climate Investment Programme (KLIMP), which targets environmentally friendly investment, again, with energy efficiency as an indirect result. Estimations of future energy savings is $0.13 \mathrm{TWh} /$ year in 2010 and $0.05 \mathrm{TWh} /$ year in 2016.

Sweden has also used a number of time limited conversion support and pure investment support schemes to both households and businesses. These have been very popular and funds have in many cases been finalized well before planned closure of the support. The following are some examples of current or past conversion support in Sweden.

- Conversion support to renewable energy source for public use

- Conversion support from direct heating in households

- Conversion support from oil based heating facilities

- Support to installation of solar heater facility in houses

- Support to installation of solar heater facility in commercial premises

- Support for installation of energy efficient windows

- Support to installations of biofuels facilities in newly built houses

Finland also has various financial incentives for energy efficiency. Perhaps the most well know and widely used is financial support for energy audits: 40 percent of the audit costs are paid by the state and financial support may also cover certain energy efficiency investments and renovations. Generally the same principles apply both to commercial buildings and residential dwellings. In 2009 energy efficiency renovations are being encouraged through financial support as part of the government's policies and financial recovery package.

Finland has a programme of Energy Assistance for Housing and provides financial assistance for investments in equipment and connection to a district heating network, if the investment would result in decreased green house gas emissions for houses of max two apartments while houses with a minimum of three apartments could apply for funding for financial assistance for energy audits, renewal of the building shell, re- 
newal of the air-conditioning system, and measures linked to the heating system and use of renewal energy.

The Finnish Ministry of Environment has established a working group to identify measures that can be used to adapt the real estate taxation to promote energy efficiency and heating system. Additionally, possible additional needs for research for development of a working and supportive taxation system are determined. The working group shall present their findings before the end of September 2009.

In addition to investment support to energy efficient investment all countries also give some kind of support or funding for research and development activities in this area, including support to demonstration projects. For instance the above mentioned Norwegian support programme for building also include support to so called model building (i.e., passive standards). In Finland the authorities provide business and operational support and funding for research and development of energy efficiency in building environments. Currently Sitra (Finnish Innovation Fund) provides funding through its energy programme (2007-2012) and Tekes (Finnish Funding Agency for Technology and Innovation) through three programmes of a total value of 170 Million Euro between 2007 and 2014.

\subsubsection{Energy efficiency regulation}

Regulation is typically defined as legal restrictions employed by governing agencies pertaining to the behaviour of enterprises and individuals. While government regulation is the basis for economic and societal interactions, the evolution of regulations with respect to economic fundamentals has improved over time. Some of the first positivistic attempts to enhance energy savings were based on blunt regulation. This took the form of emissions or energy use targets that could be met through the application of regulation by force, if necessary. Blunt regulations are most useful in cases where there is a need to either ban or drastically reduce the use of dangerous substances or processes. The major economic obstacle concerning regulations is that they do not account for different cost structures for different actors. Demanding the same energy use reduction amongst all actors might prove more costly than obtaining larger reductions from actors who can reduce their energy use at a lower cost than others.

Much of the current regulation, especially in Europe, has favoured working with and modifying economic incentives to promote the policy goal, rather than running against the prevailing economic dynamics. Thus, using the lessons gained from regulatory experience, new energy policy regulations can utilize a blend of carefully crafted incentives and board mechanisms to maximize benefits and ensure that competitive markets remain intact. 
An example of regulative policy is the obligation for Danish distribution companies to save energy at the end-user level. The Danish government has entered into an agreement with energy distribution companies in electricity, gas and petroleum on quantitative energy saving targets. The energy saving targets are inscribed in the law and applies to the period of 2006-2013. Targets are specified by sector (electricity, natural gas, district heating and petroleum) and in total the energy distribution companies have agreed to realise 2.94 PJ savings per year for the period 200613. With the new political agreement of February 2008, the annual target from 2010 and onwards were increased to 5.4 PJ.

\section{EU Energy Performance of Buildings Directive}

An important regulatory instrument for the building sector is the EU Energy Performance of Buildings Directive 2002/91/EG, EPBD. This directive will be an important instrument to promote development and use of more energy effective buildings, both in construction, and renovation of existing buildings. The directive has five main requirements:

- A method for calculating the integrated energy performance of buildings;

- Minimum requirements of energy performance for new buildings and for large buildings being renovated;

- Energy certification of buildings;

- Inspection of heating system with boilers; and

- Inspection of air conditioning system and an evaluation of heating systems older than 15 years.

The Swedish National Board of Housing, Building and Planning (Boverket) and Energy Agency (Energimyndigheten) were assigned by the Swedish Government in 2003 to propose how the EU Directive 2002/91/EG should be implemented in Sweden. The first two requirements in the directive have been cared for by amendments in the building regulations, managed by the National Board of Housing, Building and Plannings, BBR 06. The BBR sets the minimum level regarding the energy performance of new buildings and the last amendments took place in 2006. The law on Energy Declarations (energy certification) for buildings was enforced in 2006 and will be fully implemented in the beginning of 2009. Regarding energy efficiency, the declaration shall contain information about energy performance, possibilities to do efficiency measures and reference values of energy performance. Regarding the inspection of heating systems with boilers, Sweden chose the alternative of providing information to end-users. The Energy Agency is in charge of the information distribution which was implemented in 2007 in parts of Sweden. Concerning inspection of air conditioning systems included in the energy declarations. 
Following the EU Directive, the Danish Government in 2006 introduced a 25-30 percent more restrictive minimum energy performance requirements for new buildings. Two new building categories for low-energy buildings were introduced as well with 75 percent and 50 percent better energy performance than the minimum building requirements. The building code will be revised again in 2010, 2015 and 2020. From 2010, more strict energy performance requirements will be incorporated assuring 25 percent better energy performance compared with current level. From 2015, the current optional low energy class 2 is expected to become the minimum requirement which means 50 percent better performance than current minimum level. A third tightening by 25 percent is expected again in 2020. The overall target for 2020 is thus that new buildings should use 75 percent less energy than required by the existing building code.

In addition to minimum requirements to new buildings and to buildings undergoing major renovations, Denmark has a number of ongoing initiatives relating to Energy Labelling of Buildings, following the Directive. A revision of the existing building energy labelling programme in Denmark has been initiated and for either of the present energy labelling programmes (for buildings above $1,000 \mathrm{~m}^{2}$ and for buildings below 1,000 $\mathrm{m}^{2}$ ) quantitative targets for energy savings have been established. Annual energy savings at 4-6 PJ from 2012 is expected by the government for all buildings concerned by the law implementing the EU building directive.

Beyond the requirements in the EU Directive, Denmark has introduced a programme of Energy Management that is regulated by law since 2005. For buildings operated by state institutions it is required that cost effective energy saving potentials identified by the mandatory energy audit each fifth year (as part of the energy labelling of buildings) should be implemented if the pay-back period ${ }^{12}$ for the building owner is assessed to be lower than 5 years. Further to this, it is mandatory for state institutions and municipalities to prioritize energy efficiency in procurement. The Danish Energy Agency (DEA) has announced that from July 2009 the requirement to implement cost effective measures will not be limited to those having a pay-back period lower than 5 years. This new initiative is developed in the context of the recent government policy target of reducing energy demand in state buildings by 10 percent in 2011 compared with the 2006-level.

Finland's response to this directive resulted in the Act on Energy Certification of Buildings and the Ministry of the Environment Decree on Energy Certification of Buildings. The Act and Decree came into force on 1 January 2008. The national building regulations on energy efficiency were also made more precise with the implementation. In connection with the Act, the Ministry of Environment issued renewed Building Codes, which cover:

\footnotetext{
${ }^{12}$ Capital cost divided by annual cost savings over lifetime.
} 
- the requirements for thermal insulation;

- energy efficiency requirements for buildings;

- methodology for calculation of energy consumption and heating capacity;

- calculation of heat loss; and

- requirements for amount of recovered heat from the exhaust air.

Already in 2000 Finland established PromisE, a system for environmental classification of buildings, as a joint initiative of the building and construction sector. It aims at creating a market-oriented tool to evaluate the overall environmental performance characteristics of a building as well as provide a tool for building design. There are separate systems for existing buildings and new construction projects. The scale of the evaluation is A$\mathrm{E}$ as in the energy certificate of EPBD. In practice the A-C labels have proved to be relatively challenging, level E representing the current norm level. In practice the PromisE tool has been useful to improve the environmental design practices within the industry, but it has not been applied in order to differentiate buildings within the market.

Norway has yet to implement EPBD fully in Norwegian law, but a proposed law concerning energy declarations was presented by the Government in December 2008. This proposal requires that owners of commercial buildings and public building over $1,000 \mathrm{~m}^{2}$ have an energy declaration for the building. Such declarations shall also exist for dwellings being sold or rented. Norway has also changed the building codes (TEK07) for new buildings, and for major renovations of buildings. The new requirements came in to force in February 2007 but with a 2.5 year implementation period (meaning that they become mandatory by August 2009), and requires that average energy use is 25 percent lower than in earlier regulations.

Tradable quotas

A specific combination of regulations and economic instruments are different type of tradable permits or quotas. In these systems the government decides how many permits should be issued (i.e., decides the wanted level of activity or emission), and then the market decides the price (subsidy) for each permit. This is a way to overcome the steering weakness of taxes and charges, where the authorities decide the price and the market decides the outcome (level of activity or emissions). Tradable quotas will ensure both cost effectiveness and steering effectiveness. Well known tradable quotas is the European Trading Scheme for $\mathrm{CO}_{2}$, and the Swedish green certificates for renewable energy. 
For energy efficiency there exist a tradable measure called white certificates. ${ }^{13}$ The most common white certificate programme revolves around mandated energy reduction targets for energy distribution or supply companies, which are fulfilled by obtaining white certificates through energy reduction at the end-user level or via purchasing white certificates from other distributors. European countries using white certificates include Great Britain, Italy and France. Denmark plans to have a system in place from 2010. The Swedish Energy Authority has assessed whether white certificates is a suitable instrument for Sweden, but the conclusion is that white certificates are an interesting instrument, but that it is too early to implement it.

\subsubsection{Informational/management assistance}

Addressing information failures is the main purpose of informational and management assistance programmes. By providing information to market participants about current regulation, initiatives and technology, government and policy administrators are better able to facilitate behavioural changes. The rationale behind such assistance programmes is that the relevant actors often are unknowledgeable about recent developments that can reduce their use and cost of energy. With information, these actors are able to more effectively and efficiently adapt to new regulatory environments, take advantage of beneficial public and private programmes, and implement new technology and processes. Additionally, eliminating this informational barrier, and providing access to management assistance enables actors to benefit from resources and information they would otherwise not utilize.

There are a wide variety of informational and management assistance programmes, where some are purely informative and others also include some type of support or tax relief.

Information is an often used instrument, but at the same time it is the weakest type of instrument the authorities possess, as there is no (guaranteed) link to actual savings. Information can therefore never be a sufficient instrument to secure savings, but is almost always a necessary complement to financial and regulatory instruments. Information can make these kinds of instruments more acceptable, and can also enable actors to adapt to increased taxes or tightened regulations.

\footnotetext{
${ }^{13}$ A white certificate scheme is a market oriented measure that, at least in theory, is supposed to yield cost-effective energy savings. The authorities set a target for energy savings that the market actors are obliged to reach. Through tradable certificates the market sets a price on energy savings that accrue to the actor saving energy. The system is parallel to a direct support scheme for energy savings, but the support is being paid by the market actors (and finally the energy user) instead of being financed through the state budget. Moreover, the scheme sets a quantitative target for energy savings to which the proper price is set in the market, whereas a support scheme typically sets a price and then a volume is realized through the market. The main advantages of white certificates are that the target is met in a cost-efficient manner. Possible drawbacks include possibly large transaction costs, and they might favour easily implemented and measurable actions, not necessarily the ones yielding the largest energy savings
} 
Information campaigns

All Nordic countries use information campaigns to spread awareness about energy savings potential. Some countries also supply publicly funded guidance to different user groups. For example, in Sweden all municipalities are required to utilize a publicly funded energy advisor, giving advice both to local enterprises and households. The service was introduced in 1998 with the aim to increase awareness among consumers regarding energy in general and energy efficiency in particular.

In Norway, this type of information campaigns are administered by the state company Enova, which provides net based guidance both on a general and a personal level. In their information activities, Enova often relies on "energy stories," where actors that have received support from Enova and implemented certain energy saving actions describing their experiences. This is a method of making public information more credible. Enova is also administering a program to support municipal energy and environmental planning. Since the Norwegian Municipals owns one fourth of all the commercial buildings in Norway and account for a third of the energy use in these buildings, a significant potential lies within this sector to reduce energy use.

The Danish Energy Agency as well as the Energy Saving Trust are frequently launching initiatives to try to spur market transformation of efficient technologies by a combination of measures such as of voluntary energy labelling of energy technologies, voluntary agreements with technology providers on phasing out conventional energy technologies, campaigns together with service providers to help spur end-users to change buying behaviour.

The Danish government intends to strengthen its initiatives targeting energy savings in buildings by launching new information activities on energy savings in new built as well as in existing buildings, i.e., by the establishment of an information/research centre on energy savings in buildings.

\section{Voluntary agreements}

A voluntary agreement between the authorities and sectors or individual enterprises, is one example of a combination of management assistance, regulation and direct or indirect support. Voluntary agreements are used in many countries in Europe, but Finland is likely the country where this practice is most widespread. The Voluntary Energy Conservation Agreements is largely considered the country's most important energy efficiency policy instrument. Enterprises that participate in this programme can receive up to 50 percent support for energy analysis and energy saving investments. In 2005, 85 percent of the energy use in the industry was covered by voluntary agreements and the impact of conservation measures implemented in enterprises and communities participating in the agreements by the end of 2004 totalled approx. 6.1 TWh per year. 
In Sweden, the ByggaBo-dialogue (the Building-Living Dialogue) was introduced in 1998 and is a voluntary agreement between the Government and 40 actors in the construction sector. Together, these actors have formulated goals of which one refers to energy efficiency within the construction sector. This goal is more specifically formulated as:

"The use of purchased energy within the sector will be cut by at least 30 percent by year 2025 compared to year 2000. Energy consumption will be lower (in) year 2010 than year 1995 ". ${ }^{14}$

Other similar initiatives in Sweden are BELOK and BeBo. BELOK is a cooperation between the Swedish Energy Agency and the largest houseowners (landlords) for commercial buildings. ${ }^{15}$ The cooperation was initiated in 2001, and the aim is to support energy efficient technologies, partly through promoting market transformation. BeBo is a similar cooperation, but targeted towards multi-dwellings (apartments). ${ }^{16}$

In Norway there is also an agreement between the government and the building industry, called Byggemiljø (BuildEnvironment) for the period 2005-2009. The aim of this agreement is to develop and spread information about energy and environmental efficiency to the building industry and their cooperation partners, and to coordinate and stimulate the efforts towards energy and the environment in the industry. Since 2007 there is also an agreement between the building industry and several governmental bodies to cooperate in Lavenergiprogrammet (Low Energy Program). The main objective of the program is to contribute to reduced energy use and an environmental friendly energy conversion in buildings, and to prepare the industry for stricter building regulations. ${ }^{17}$

Public procurement, etc.

Requiring or encouraging the public domain to act as a role model is also a frequently used measure. For instance, Sweden has a programme of public procurement of energy efficient technologies which is estimated to have saved 4,027 GWh during 1995 to 2005. Denmark has a similar programme; however, it is more firmly regulated by law as described above. The aim is that the public sector should "show-the-way for other sectors".

In Denmark, buildings owned and/or rented by state institutions have been required by law since 2005 to identify cost effective energy saving potentials by mandatory energy audit each fifth year (as part of the energy labelling of buildings) and to make these investments within a period of 4 years from the audit. The municipalities have committed themselves in an agreement with DEA to meet the same requirements as those applying to buildings operated by state institutions. Furthermore, it is

\footnotetext{
${ }^{14}$ http://www.byggabodialogen.se

15 www.belok.se

${ }^{16}$ www.bebostad.se

${ }^{17}$ www.bnl.no
} 
mandatory for state institutions and municipalities to prioritize energy efficiency in procurement, behaviour, operation and maintenance.

Finland's energy efficiency requirements for public procurement are mostly focusing on other issues than buildings. However, energy aspect is increasingly been taken into account in (public) procurements and innovative instructions have been developed e.g., by Motiva and Tekes.

The Ministry of Trade and Industry issued recommendations in 2000 concerning the energy efficiency of public purchasing. According to the recommendations, the evaluations of economic aspects should include the quality, life expectancy, energy costs and environmental impacts of the use. The recommendations are currently under revision and being discussed by the Working Group on Public sector Purchasing Action Plan.

\section{Networking}

Energy Networking are networks for certain industries with the aim to exchange information/experience on energy efficiency and also benchmark energy performance. Norway has a Building Network were building owners report their energy use in specific buildings, and where this data is being used to benchmark against other buildings of the same type (for instance offices, schools and hospitals). The members have all received a grant from Enova to perform energy audits and install certain energy saving equipment.

\section{Demand Side Management (DSM)}

Demand Side Management entails actions that influence the quantity or patterns of use of energy consumed by end-users, such as actions targeting reduction of peak demand during periods when energy-supply systems are constrained. Peak demand management does not necessarily decrease total energy consumption but could be expected to reduce the need for investments in networks and/or power plants.

In Sweden, distribution companies are installing automatic hourly meters, and automatic meters are expected to be installed for all end-users by mid-2009. The background for this is a Swedish law requiring distribution companies to have monthly meter readings. As monthly manual meter reading would be too costly, the distribution companies are going ahead and installing automated hourly meter readers, i.e., the data about consumption is transmitted automatically to the distribution companies. It should be pointed out that the motivation behind the Swedish law is not to promote Demand Response, but to ensure correct billing.

In Finland the government issued Government Degrees on electricity markets and on surveys and measurement of Energy distribution in February 2009. These degrees obligate distribution companies to provide their clients hourly meter readings without additional charge. In order to achieve this, automatic meters must be installed and the objective is to cover 80 percent of customers by 2013. The change brings cost savings to 
consumers and electricity producers and improves energy efficiency as well as supply reliability and cost efficiency.

\subsubsection{Local instruments}

In Sweden there are several instruments administered and decided on centrally, but implemented on the local level. The above mentioned LIPand KLIMP-programmes as well as municipal and regional energy advisory service are implemented on municipal level. The Region Västra Götaland initiated in 2007 a three year program worth 24 million SEK for energy efficient buildings. The scope of the program includes among other things energy efficient buildings (passivhus), dissemination of information, advice and education, research and development. Västra Götaland is one of the bigger regions in Sweden with about 17 percent of the total population.

In Denmark granting of permits for building construction is a municipal task and municipalities in Denmark are increasingly requiring that new buildings should go beyond the minimum energy requirements of the Building Code. Further to this, some municipalities are engaged in creating awareness in their citizens, local industry and service sectors about energy savings and/or climate change abatement. Instruments include supporting establishment of networking groups, voluntary commitments related to procurement of goods and services and establishment of energy accounts and energy management systems.

Finnish municipalities are relatively active in promoting sustainable development and energy efficiency. Cities are required to present an action plan how the requirements of Energy Savings Directive are fulfilled on a local level. The plans should have been prepared at the end of 2008 and therefore most Finnish municipalities have established or are in process of establishing their own local agenda for sustainability assessing also the construction and use of buildings.

The city of Salo has implemented more strict energy regulations in city planning than required by the state. Similarly, a new development project is ongoing in Porvoo, where "energy city plan" practices are being developed. The Ministry of Environment encourages municipalities to implement innovative solutions by accepting certain exceptions in current practices if energy efficiency is improved. The building supervision in the city of Oulu has showed excellent results for active information and training campaigns. Every family that plans to build a single-family house (or similar) are being invited to educative meetings where energy efficiency issues are demonstrated and families guided. Building's energy efficiency targets and practices are also addressed in some regional climate change strategies, perhaps the most comprehensive been established for Helsinki Metropolitan area by Helsinki Metropolitan Area Council (YTV). 
In Norway there are few local instruments in use, except that several municipalities participate in different programmes in order to make their own activities more sustainable. Examples of such programmes are "Livskraftige kommuner" (sustainable municipalities) and "Grønne energikommuner" (green energy municipalities). In Oslo the municipality offers support to certain energy saving investments in private households, like insulation, installing steering systems and heat pumps. Owners of commercial buildings can also obtain support to perform energy audits in Oslo.

\subsection{Conclusions on the use of instruments}

There are several rationales for public intervention in order to increase the energy efficiency. These rationales can be found in different forms for market failures that exist regardless of political targets (like the existence of externalities, market power and asymmetric information). Other justifications are based on political targets, for instance regarding emissions of greenhouse gasses and security of energy supply.

The energy policies in the Nordic countries are all based on the climate challenge, the need to secure supply and to ensure a competitive market with reasonable prices. Instruments to promote energy efficiency are normally a part of the two first challenges. The last target, reasonable prices, can, however, be in direct conflict with instruments to promote energy efficiency. Promotion of new renewable energy can also be a part of addressing the two first challenges, but can also be in conflict with increased energy efficiency. The latter can be the case if subsidies to renewable energy contribute to lower end-use prices, which will counteract energy savings.

The description of measures being used shows that all countries use a mix of fiscal, regulatory and informational instruments. Sweden and Denmark seem to be the countries with the most diverse portfolio, whereas Norway, which primarily uses investment support, is on the other end of this scale. The prime instrument in Finland is voluntary agreements, but there also exist several other types of measures.

It is not always easy to compare the countries' use of instruments for energy efficiency, since there are many different designs of these instruments. Regarding economic instruments elements like tax base, exceptions, rates, etc. differ and makes comparison difficult. However, for all the four countries investigated the following economic instruments can influence energy efficiency:

- Excise taxes on electricity and fuel oil use;

- $\mathrm{CO}_{2}$ taxes on fuel oil and transportation fuels. These taxes were introduced in the early 1990s; 
- $\mathrm{CO}_{2}$ emissions trading. Only Denmark and Norway have adjusted their $\mathrm{CO}_{2}$ taxation schemes to avoid or reduce "double-taxation" of some emissions; and

- Subsidy schemes for energy efficiency, but with large variations. 



\section{How do the policies perform?}

In this chapter we take a closer look at what energy efficiency policies and instruments have delivered historically, based on earlier performance evaluations. We also discuss how the actual savings have been or can be used, i.e., if some of the initial savings have been counteracted by so called rebound effects.

\subsection{Performed evaluations}

\subsubsection{Denmark}

Impact of taxes

The Ministry of Economic and Business Affairs estimates the combined impact of energy and carbon related taxes and the European Emissions Trading Scheme to correspond to a 10 percent decrease of final energy demand of Denmark or equivalent to energy savings at 43 PJ (or 11.3 TWh) (Danish Ministry of Economic and Business Affairs, 2008).

\section{Evaluation of energy efficiency measures}

The Danish Energy Agency has recently initiated an independent evaluation of some of the major governmental measures targeted energy savings and energy efficiency improvements. The evaluation results are summarized below with regard to quantification of savings achieved by the measures (Danish Energy Agency, 2008).

For energy labelling of buildings, the evaluation team found that it was doubtful if the savings achieved would not have happen in the absence of the energy labelling, as there was no significant difference in energy saving behaviours of buildings participating in the energy labelling programme and those not participating in this programme. The evaluation team estimates the impact of energy labelling to be $0.02 \mathrm{PJ}$ measured as first year savings (new savings the first year) which is substantially lower than the $0.5 \mathrm{PJ}$ expected by the Ministry of Transport and Energy.

The energy distribution companies are estimated by the evaluation team to realize annual energy savings corresponding to $1.5 \mathrm{PJ}$ under the agreement with the government on energy savings obligations of the distribution companies. This corresponds to half of the current target (which is $2.95 \mathrm{PJ}$ per year). 40 percent of reported savings have been achieved in household, 8 percent in public sector and 50 percent in industry, where 
the major part stems from savings in process energy. Only 50 percent of reported savings are estimated by the evaluators to be additional savings. Even when assuming that 50 percent of the reported savings would have happened also without the agreement and that additional annual savings would stay additional for a period of 5 years only, the measures are evaluated by the evaluation team to be cost effective to society and to the user (pay-back period is 5 or less than years).

The evaluation team did not estimate quantitatively the impact of the Electricity Saving Trust and the recent revisions of the Building Code. The expectation of the Ministry of Transport and Energy (in 2007) was, however, that the recent revisions of the Building Code will lead to savings corresponding to $1.75 \mathrm{PJ}$ new savings per year and that the Electricity Saving Trust will lead to 0.6 PJ new savings per year.

\subsubsection{Finland}

For Finland no policy evaluations of existing or historical measures have been identified. There are however several extensive evaluations of savings potentials by VTT, Technical Universities and Sitra (the Finnish Innovation Fund), see chapter 6.

\subsubsection{Norway}

Evaluation of Enovas building programmes

An evaluation of the programme "Energy management for buildings" (the predecessor of Enova programs for households and industrial buildings) showed that the buildings participating in the Building Network in 19962002, on average, had a reduction in energy consumption of nearly 7 percent, which is less than the prior estimated potential of 10 percent, see Econ (2004). There are major uncertainties in this calculation that works in both directions, but it is likely that the real savings can be 1-2 percent higher than the calculated. The support for the projects have predominantly been of importance for the savings, i.e., that there are few free passengers involved and the additionality was supposed to be rather high. Enova has rationalized the operation of the programs, and the cost per building involved was almost halved from 2001 to 2003.

Econ Pöyry (2007a) also carried out an evaluation of the Enova programme for households and industrial buildings ("bygg, bolig og anlegg”) for the period 2004-2007. The evaluation report concluded that it was difficult to find evidence of the impact and target achievement of the programs due to lack of documentation of actual savings. Nonetheless, there was no doubt that the program has had a number of beneficial consequences. For the period 2004-2006, Enova contracted 1.2 TWh (that is contracts were signed with building owners who stated that 1.2 
TWh should be saved), but by the time the programme was evaluated only a few percentage of this had actually been reported as performed.

Temporary support to households in 2004

During the winter 2003/2004 Enova administered a temporary support scheme for households that invested in heat pumps, pellet, or energy management systems. The system was evaluated in 2005, see Bjørnstad et al. (2005). The extent of the support scheme was significantly larger than predicted, and it attracted more than 50,000 applications, of which 47,000 were granted, and almost 20,000 were actually performed. Over 90 percent of the total grant amount went to the heat pumps. The grant scheme thus had very different impacts on the three eligible technologies. For those households where the investment mainly replaced electric heating, the average annual savings was estimated at $6,000 \mathrm{kWh}$ per year, representing about a third of the total electricity used for heating in these households. The savings was largest for pellet stoves (43 percent) and smallest for management systems (18 percent). The support scheme was introduced in a winter with extreme price fluctuations on electricity, where it already saw strong growth in the sales of energy saving equipments before the scheme was launched. In the evaluation a high percentage of households answered that they would have bought new heating technology without the subsidy, i.e., that the system had a high proportion of free passengers. For heat pumps the scheme probably affected the market situation significantly, and contributed to market introduction. The evaluation estimated a diffusion effect of 5.5 percent, meaning that 1,000 households conducted investments without actually receiving support, but as an indirect result of the scheme.

Evaluation of taxes and duties

In 2007 a public assessment group (“Særavgiftsutvalget”) evaluated among other things the environmental taxes levied by the state, see NOU (2007). According to this evaluation the electricity and general mineral oil taxes have an unclear purpose, as they could either have a fiscal or an energy policy purpose. They could hardy be seen as environmental policy instruments, since the electricity tax is imposed on all electricity consumption regardless of environmental damages, and the mineral oil tax is not levied on fuels according to emissions. The main purpose therefore seems to be fiscal. If so, all industry sectors should be exempted from the taxes, and all households should pay the same rates (NOU, 2007). If the taxes are imposed for energy policy reasons, the purpose should, according to NOU (2007), be further elaborated and the taxes designed accordingly. It has been a political goal to reduce and gradually phase out the use of fuel oil, and the mineral oil tax could eventually be seen in this light, although this is not stated as a goal for the tax. 
Overall, NOU (2007) concludes that the Norwegian economic instruments seem to have worked rather well. The various taxes are designed in a way that to a considerable extent facilitates cost effective emissions reductions, this applies also to those taxes that are imposed mainly for fiscal reasons.

\subsubsection{Sweden}

\section{Evaluations of conversion support}

An evaluation of the conversion of oil heating systems concluded that the energy use for heating has declined and so has the CO2-emissions (National Board of Housing, Building and Planning, 2007). According to the National Board of Housing, Building and Planning CO2-emissions of 0.5 millions tonnes has been avoided as a result of the support. The use of oil has declined and with an increased rate. The overall energy use in one and two dwelling buildings has not decreased though, which was not, however, the purpose of the support. However, the National Board of Housing, Building and Planning also conclude that conversion of oil heating was economically profitable for the house owner even without the support and therefore questions the rationale behind the support.

The conversion support switching from direct heating to district heating has been evaluated by the National Board of Housing, Building and Planning as well. There were no quantitative goals for this support. Most of the conversions took place in the northern part of Sweden. The measures realised under this support are estimated to reduce electricity use by 189-191 GWh per year. The electricity saved per support SEK is 0.64 KWh. Another study made by Econ Pöyry notes, in line with previous studies, that the support does not reach its original quantitative goals (Econ Pöyry, 2007d). According to this analysis this is partly due to the lack of resources stemming from administrative overload, since the responsible authorities also administered the oil conversion support. Support for conversion from oil also overshadowed the support for conversion from direct electric heating. This led to confusion among potential recipients regarding the conditions for support. It is also noted that its performance varies across the country and that this is largely due to the varying opportunities to convert to district heating. A limited expansion of district heating network is apparently the main reason why the support scheme has not reached the implicit quantitative goals. The evaluation also found that the additionality of the support was relatively low.

In addition, in connection with the so called Energy Efficiency Study (energieffektivitetsutredningen, SOU (2008c)) the Swedish Energy Agency commissioned Profu to assess the effects of the conversion supports. For the period of 1995 to 2005, a substantial number of heating system conversions have taken place in Sweden. However, it is not only various policy measures that is the underlying factor for change but also 
increased oil prices. Hence, some of these conversions could potentially have taken place even without state support. Only buildings that were in place in 1995 were included, hence no new buildings or buildings that were torn down prior to 2005 were included.

The assessment specifically looked at the buildings net heating demand conversions exclusive of improvements in efficiency, improved efficiency from individual heating as well as energy efficiency reached through improved infrastructure. The reductions are mainly due to conversion from oil based heating systems. The findings of SOU (2008c) are presented in table 5.1. According to SOU (2008c), 10 percent of the energy savings would have taken place without the conversion supports.

Table 5.1 Reduction in energy consumption, per type of building

\begin{tabular}{lcc}
\hline & $\begin{array}{l}\text { Final energy consumption } \\
\text { (TWh) }\end{array}$ & $\begin{array}{l}\text { Primary energy consumption } \\
\text { (TWh) }\end{array}$ \\
\hline One- and two-dwelling houses & 5,5 & 8,1 \\
Multi dwelling houses & 1,4 & 2,3 \\
Premises (lokaler) & 4,5 & 6,9 \\
Total (minus 10 percent) & 11,2 & 17,1 \\
\hline Source: Sou 2008:25 & &
\end{tabular}

Procurement of efficient technologies

The efficiency gain related to technical procurements and so called procurement groups (like BELOK and BeBo described in chapter 4) is of long terms impacts, and covers both direct and indirect impacts. The evaluation of the effect of the ten most important procurements that the Energy Agency has carried out is somewhat conservative according to the Energy Efficiency Study and hence the estimates have been adjusted (SOU, 2008c). This assessment is only to show the effect of technical procurements and they only represent ten out of a total of 50 procurements. Table 2.2 shows the direct effect of the public procurement, i.e., the reduction in final energy consumption that can be directly linked to the procurement. As can be seen, the procurement of heating pumps conducted in 1995/1996, contributes substantially to the reduction. However, there are likely to be a number of spill over effects due to the public procurement of technical goods. For example, a producer that did not win the tender but that did develop a more energy efficient product that could be sold on the private market is not included in the estimates below.

Table 5.2 Reduction in energy use, procurement

\begin{tabular}{lcc}
\hline & $\begin{array}{l}\text { Final energy consumption } \\
\text { (TWh) }\end{array}$ & $\begin{array}{l}\text { Primary energy consumption } \\
\text { (TWh) }\end{array}$ \\
\hline Sum (TWh/yr) & 1,6 & 2,4 \\
Sum (excl heating pumps) (TWh/yr) & 0,61 & \\
\hline
\end{tabular}

Source: (SOU 2008:25) 
Labelling

According to the Swedish Energy Agency and the Swedish Consumer Agency (Konsumentverket), the introduction of labelling of household appliances has greatly improved the supply and sales of energy efficient products. It is estimated that the average energy needed per product has decreased with approximately 50 percent since the introduction of the labelling. SOU (2008c) makes a conservative judgement that the labelling has resulted in a efficiency of 0.3 TWh of final energy consumption, approx 0.8 TWh of primary energy by 2016. This is based on assumptions that 50 percent of all Swedish household have chosen to switch to more energy efficient appliance compared to what they would have chosen without the labelling.

\section{KLIMP and LIP}

Other support programmes that are thoroughly evaluated are KLIMP and LIP, for example by the Swedish Environmental Protection Agency (2008). According to this study the emissions of GHG will decrease with 2.1 millions tonnes a year. The cost is circa 100 SEK/tonne. Energy consumption is estimated to decline with $2.1 \mathrm{TWh}$ per year. According to another evaluation the future energy savings will be $0.23 \mathrm{TWh} /$ year up to 2016 for LIP and 0.13 TWh per year up to 2010 and 0.05 TWh/year up to 2016 (Swedish Energy Agency, 2007).

\section{Effects of taxes}

In connection with the Energy Efficiency Study (SOU, 2008c) Dr Dargay at the University of Leeds assessed the effect of taxes on energy efficiency, using econometric methods, for the period of 1990 to 2016. The overall estimation for the period shows that the energy taxes, contributed to a more efficient final energy usage of at least $3.4 \mathrm{TWh}$, equalling 6.7 TWh in primary usage.

The Swedish system encompasses many economic instruments aimed at reduced climate impacts. Evaluations show that amongst these instruments, multi-sectoral taxes, such as the carbon dioxide tax, are the instruments with the greatest socio-economic potential for influencing behaviour in the interests of sustainability. Grants and tax relief are generally believed to be less effective in the long term (Swedish Environmental Protection Agency, 2004).

It has also been concluded that the present energy tax system is a more effective means of reducing carbon dioxide emissions than the system existing in 1990. According to recent evaluations, emissions of carbon dioxide have fallen substantially compared with the reduction that would have been achieved if the 1990 energy tax regime had remained in place. Industrial emissions are, however, believed to be somewhat higher with the current reduced-rate carbon dioxide tax than they would have been under the 1990 energy tax regime (Swedish Energy Agency, 2006). 
The electricity tax can also be viewed as reaching its goal but is only cost-effective within industries and regions, not between them. This is because it cannot be regarded as cost-effective to differentiate the tax rate between northern and southern Sweden. This differentiation may instead be justified on grounds of wealth redistribution or regional policy. Another reason used to justify that the manufacturing industry pays a lower rate (SEK $0.005 / \mathrm{kWh}$ ) than for example the service industry is that manufacturing industry faces foreign competition (Swedish Environmental Protection Agency, 2006).

\subsubsection{Comparing the evaluations}

The scope of evaluations differs in different countries. Sweden seems to be the country with the most extensive evaluations of energy efficiency measures. The measures evaluated, and the focus of the evaluations differ between the countries, may be with the exemption of energy taxes, that have been evaluated both in Sweden, Denmark and Norway. The results of these evaluations are quite different, where Denmark experienced greater savings. None of these evaluations include an assessment on the effects of costs and savings for the society.

In Denmark, Norway and Sweden there are measures taken where the savings would have been realized even without the support. In Sweden it is true for the support for converting from oil heating in building, in Denmark for the energy labelling of buildings and the agreement between government and distribution companies and in Norway for the temporary support to households in 2004. The energy labelling in Denmark has however been assessed to be cost effective to society and to the user even if parts of the savings would have occurred without the agreement.

There are no measures that strike as more efficient than others. It is however important to perform evaluations on the efficiency measures in order to pursue the most efficient politics.

\subsection{Are there rebound effects?}

The rebound effect refers to the idea that some or all expected reductions in energy use as a consequence of energy efficient improvements are offset by increased demand for energy. In the literature one distinguishes between three types of rebound effects: direct, indirect and economy-wide:

- Direct rebound effect: Improved energy efficiency for a particular energy service will decrease the effective real price of that energy service. If an energy service becomes less expensive due to efficiency measures taken, consumers may choose to buy that energy service 
more often. The direct rebound effect is thus the extra energy used as a result of cheaper energy services. This effect may also be referred to as price effect.

- Indirect rebound effect is also a result of the decrease of money spent on a particular energy service following an efficiency measure taken. In this case however, the consumer chooses to spend the money saved on other products than the initial energy service. The other products bought may be more energy intense than the initial energy service. This effect may also be referred to income effect.

- Economy wide rebound effects: The indirect rebound effects on the individual level may be relatively small. However, the cumulative impact of several energy efficiency measures could be large. A fall in real prices of energy intensive goods relatively to non-energy intensive goods may increase the relative consumption of the energy intensive goods.

There are however scientists putting forward a fourth category, the transformational effects. This category includes the impacts of technological advances on consumers' preferences and allocation of time. These effects may change energy demand in any direction (Nässén, 2007).

\subsubsection{Empirical studies of the rebound effect}

Several empirical studies confirm the existence of rebound-effects related to most actions for energy efficiency. The estimated effects vary a lot. While some studies conclude that the rebound effect is so weak that it can be ignored, others find that the effects are big enough to more than compensate for the initial savings. There is also reason to believe that the rebound-effect can be smaller on short-term than long-term. This is due to efficiency actions will lead to long-term behaviour change that will be significant for the total use of resources.

Most of the empirical studies have analysed the direct rebound effect. Some studies do not however include any quantitative results. The studies presented in 5.3 differ in several aspects. They are the result of different assumptions, analysing different types of technological changes. They do however show that there is no real evidence of the magnitude of the rebound effect. 
Table 5.3 Examples of rebound studies

\begin{tabular}{|c|c|c|}
\hline Study & What & Result \\
\hline Dubin et al, 1986 & $\begin{array}{l}\text { Direct rebound effect of energy } \\
\text { efficient technologies, heating } \\
\text { and cooling in the US }\end{array}$ & $\begin{array}{l}\text { A rebound effect of } 8-12 \\
\text { percent for heating and } 13 \\
\text { percent for cooling. }\end{array}$ \\
\hline Hirst et al., 1985 & $\begin{array}{l}\text { Direct rebound effect of energy } \\
\text { efficient technologies, heating } \\
\text { and cooling in the US }\end{array}$ & A rebound effect of 10 percent \\
\hline Dinan and Trumble, 1989 & $\begin{array}{l}\text { Direct rebound effect of energy } \\
\text { efficient technologies, heating } \\
\text { and cooling in the US }\end{array}$ & A rebound effect of 10 percent \\
\hline Haas \& Biermayr, 2000 & $\begin{array}{l}\text { Direct rebound effect of energy } \\
\text { efficient technologies, heating } \\
\text { and cooling in Austria }\end{array}$ & $\begin{array}{l}\text { A rebound effect of } 20-30 \\
\text { percent. }\end{array}$ \\
\hline Milne and Boardman (2000) & $\begin{array}{l}\text { Direct rebound effect of energy } \\
\text { efficient technologies, heating } \\
\text { and cooling in UK. }\end{array}$ & $\begin{array}{l}\text { It shows that the initial indoor } \\
\text { temperature in relation to } \\
\text { comfort temperature was of } \\
\text { importance. The rebound } \\
\text { effect was much smaller in } \\
\text { those household already } \\
\text { having a comfort temperature. }\end{array}$ \\
\hline Alfredsson, 2004 & $\begin{array}{l}\text { Indirect rebound effect as a } \\
\text { result of households adopting } \\
\text { green consumption in Sweden }\end{array}$ & $\begin{array}{l}\text { The conclusion of this study is } \\
\text { that adopting "green" con- } \\
\text { sumption patterns without } \\
\text { reducing the overall level of } \\
\text { consumption, will not make a } \\
\text { large difference. What can be } \\
\text { achieved in a short-term } \\
\text { perspective (immediately, or } \\
\text { at least by 2010) by adopting } \\
n \text { almost completely "green" } \\
\text { consumption pattern is a } \\
\text { reduction in energy require- } \\
\text { ments of no more than } 8 \\
\text { percent and CO2 emissions of } \\
\text { no more than } 13 \text { percent. }\end{array}$ \\
\hline Brännlund et al., 2007 & $\begin{array}{l}\text { Direct and indirect rebound } \\
\text { effect }\end{array}$ & $\begin{array}{l}\text { A rebound effect of } 7 \text { percent } \\
\text { for } \mathrm{CO} 2 \text {. }\end{array}$ \\
\hline Allan et al, 2007 & $\begin{array}{l}\text { Indirect rebound effect (assu- } \\
\text { med an investment cost of zero) }\end{array}$ & $\begin{array}{l}\text { A rebound effect of } 30-50 \\
\text { percent }\end{array}$ \\
\hline Nässén, 2007 & $\begin{array}{l}\text { Direct and indirect rebound } \\
\text { effects of energy efficiency and } \\
\text { energy conserving behaviour in } \\
\text { households. }\end{array}$ & $\begin{array}{l}\text { A rebound effect of energy } \\
\text { efficiency } 5-15 \text { percent and of } \\
\text { energy conserving behaviour } \\
\text { of } 10-20 \text { percent. }\end{array}$ \\
\hline $\begin{array}{l}\text { Cambridge Centre for Climate } \\
\text { Change Mitigation Research, } \\
2006\end{array}$ & $\begin{array}{l}\text { Indirect and economy wide } \\
\text { rebound effects. }\end{array}$ & $\begin{array}{l}\text { A rebound effect of } 11 \text { percent } \\
\text { as a result of energy efficient } \\
\text { measures in the UK during } \\
2000-2010 \text {. }\end{array}$ \\
\hline
\end{tabular}

A research on Swedish households shows significant rebound-effect (Brännlund et al., 2007). The effect counteracts the original effect and if one looks at changes in emissions of climate gasses, they will increase due to the energy efficiency. This means that in some cases, the energy efficiency goals can be directly in conflict with other goals, i.e., climate and other environmental goals. A conclusion from this paper is that if energy efficiency is itself a goal, efficiency can be stimulated, while if energy efficiency is used as instrument to achieve other goals (i.e., political climate), it may be an inefficient instrument. 


\subsubsection{Implications on energy efficiency measures}

Nässén (2007) analyses in what way different parameter assumption affect the magnitude of the rebound effect. According to his results the rebound effect depends strongly on the price elasticity of energy service and the ratio of investments to break even investments. A higher price elasticity for energy service results in a higher rebound effect. The lower investment cost the higher rebound effect.

Herring and Roy (2007) discusses something similar, and states that technological efficiency measures alone will not be sufficient to reduce energy consumption, due to the rebound effect. Other instruments such as taxation and regulation would be required to change the behaviour of energy consumers.

Mizobuchi (2008) touches the same subject. He states that a relatively high capital cost, for example, the cost of buying and installing a new energy efficient appliance reduces the rebound effect.

According to the results of Nässén, partly supported by Mizobuchi, measures to improve energy efficiency should target those energy services which have a low price elasticity. Examples of these might be indoor temperature settings. The investment cost of the efficiency measure must, at the same time, not be to low, indicating that 100 percent state funded efficiency investments may incur high rebound effect.

Rebound effects have not been an issue in the evaluations presented in this report. However, it is plausible that an eventual rebound effect has been accounted for already before initiating an energy efficiency program, i.e., that the target for each program is net of rebound effects. 


\section{Future potentials for energy savings}

In this chapter we take a closer look at estimates of the potential to further increase the energy efficiency in buildings. The aim has been to identify the economical potential, i.e., savings that are economically attractive to the society up to 2020. The scope in identified studies do, however, differ in regard to their level of detail, potential identified (technical and/or economic) and time frame, and hence it has not been possible to find the total economic potential in the countries. Our assessment merely gives an indication of possible potentials to save energy in buildings in a ten year horizon.

\subsection{Identified potentials in Denmark}

The most recent assessment by DEA of the overall energy saving potential in Denmark was made in 2004 (Danish Energy Agency, 2004), supporting the governmental action plan from 2005 on energy savings. It estimates energy saving potentials using two approaches: (1) the saving potential that would be cost effective to users to utilise and (2) the saving potential that would be cost effective to society to utilise. In order to be pursued by governmental measures, an energy saving potential should meet the criteria of being attractive to the society.

According to the analysis energy savings with a lifetime of 5 years should cost between 200 to 700 DKK per saved GJ ${ }^{18}$ dependent on the type of primary or secondary energy (electricity, fuel oil, natural gas, district heating generated from natural gas, district heating generated from coal). Measures to save electricity with a lifetime of up to 5 and with a yearly cost exceeding $700 \mathrm{DKK} / \mathrm{GJ}$ would not be cost effective to society. Attractive energy savings with a lifetime of 100 years lies in the range of DKK 700 (for heating based on natural gas) to 2,500 DKK per saved GJ per year (for electrical heating.) (Corresponding to DKK 145 and DKK 695 per saved MWh) The cost calculations consider both investment costs and costs to implement the measures.

In the following sections, results of various studies on energy saving potentials in buildings in residential and public sector are presented. The technical energy saving potentials are estimated from bottom-up analysis and, as they take into consideration the best-available-technologies up to

\footnotetext{
${ }^{18}$ Corresponding to DKK 55-145 per saved MWh.
} 
2015, they are believed to include the technical potential in existing as well as new buildings.

\subsubsection{Residential buildings}

Heating

The Danish Building Research Institute (SBi) studied the heat saving potential in existing residential buildings built between 1930 and 2003 (Wittchen, 2004). The study investigates the technical potential for heat saving by means of improving U-values ${ }^{19}$ of walls, roofs and windows. Overall energy saving potential is estimated to be $8.3 \mathrm{TWh}$, or 15 persent of the corresponding demand in 2003, see table 6.1. ${ }^{20}$

Table 6.1 Heat saving potential in existing residential buildings

\begin{tabular}{llllll}
\hline Comfort heating & \multicolumn{2}{c}{ Annual heat demand, in TWh } & \multicolumn{2}{c}{ Saving } \\
& Single family & $\begin{array}{c}\text { Multifamily houses } \\
\text { and building blocks }\end{array}$ & Total & TWh/yr & percent \\
\hline house & 4.84 & 1.23 & 6.07 & 0.71 & 12 \\
Foof & 8.13 & 1.75 & 9.88 & 1.17 & 12 \\
Outerwall & 10.23 & 3.80 & 14.03 & 2.52 & 18 \\
Windows & 6.15 & 2.39 & 8.54 & 3.87 & 45 \\
Ventilation & 7.08 & 3.95 & 11.04 & & \\
Hot tap water & 2.99 & 1.56 & 4.54 & & \\
In total & 39.41 & 14.68 & 54.09 & 8.27 & 15 \\
\hline
\end{tabular}

Source: SBI, 2004

The technical energy saving potential in residential households was studied by Birch \& Krogboe (2004). In this report, the technical saving potentials that could be utilized in the very short term (4 years in most cases) using best available technologies, are assessed. In addition, it looks at saving potentials on the longer term given forecasts on future best available technologies. Only technologies that are economically attractive to the users are considered. This is assessed from criteria of maximum length of pay-back period being acceptable to the users. The acceptable pay-back period is generally assumed to be $0-4$ years except for heat savings for which 8-10 years is taken to be an acceptable pay-back period due to the longer lifetime of heat savings measures.

\footnotetext{
${ }^{19} \mathrm{U}$-value measures the rate at which heat is lost through material. The lower the amount of heat lost, the lower the energy wastage and the lower the U-value.

${ }^{20}$ Assuming that 50 percent of the potential for insulation of roofs, floor and walls are realized and that 100 percent of the potential for renewing windows is utilized.
} 
Table 6.2 Technical heat saving potential by residential sector being attractive to users, TWh

\begin{tabular}{lll}
\hline & $\begin{array}{l}\text { Saving Potential on short term. in } \\
\text { TWh }\end{array}$ & $\begin{array}{l}\text { Saving Potential on longer-term } \\
\text { (up to 2015) in TWh }\end{array}$ \\
\hline Roof & 0.48 & 1.93 \\
Floor and foundation & 0.78 & 3.12 \\
Outer walls & 1.69 & 4.51 \\
Windows & 3.09 & 2.75 \\
Ventilation & 1.80 & 2.25 \\
Hot tap water & 1.22 & 1.48 \\
Total & 9.07 & 16.04 \\
\hline
\end{tabular}

Source: Birch \& Krogboe, 2004

The methodology allows summing up the short term and the longer term saving potential. Accordingly, the overall heating potential for the residential sector through 2015 is estimated to be 25 TWh. The short term savings potential is in the same order of magnitude as the heat saving potential identified by SBI (Wittchen, 2004), that is approximately 8 TWh.

However, only parts of the overall technical saving potential (short term plus long term) is assessed by the DEA to be attractive to the society as the costs of realising parts of the potential exceed the value to the society of the corresponding fuel savings (Danish Energy Agency, 2004). The guiding principle of the government's action plan on energy savings from 2005 is that savings potentials which are not attractive to the society should not be pursued by governmental measures.

Danish Energy Agency (2004) assesses that most of the measures improving insulation in residential buildings would be cost effective to the society while replacement of windows are not, unless the investment of the user is paid back by the heat saving obtained in less than 4-6 years.

DEA believes that the heat saving potential in residential buildings being cost effective to society totals $12.4 \mathrm{TWh}$, broken-down on areas as given in table 6.3.

Table 6.3 Heat saving potentials in residential buildings being cost-effective to society

\begin{tabular}{llll}
\hline & $\begin{array}{l}\text { Maximum saving potential } \\
\text { In of demand percent }\end{array}$ & \multicolumn{2}{c}{ Heat saving potential being attractive to society } \\
& In of demand percent & In energy (PJ)/yr \\
\hline Roof & 50 & 30 & 1.83 \\
Floor and foundation & 50 & 20 & 1.97 \\
Outer walls & 55 & 25 & 3.50 \\
Windows & 85 & 30 & 2.56 \\
Ventilation & 45 & 15 & 1.67 \\
Hot tap water & 73 & 20 & 0.92 \\
Total & & 23.00 & 12.44 \\
\hline
\end{tabular}

Source: DEA 
Electricity savings in households

According to the Danish Energy Agency (2004), investments in electricity savings with pay-back periods for the user lower than three years are attractive to society. This is based on an electricity price of 111 DKK/MWh and lifetime of measures lower than 10 years. Given these criteria and assumptions, DEA estimates the maximum saving potential in electricity appliances in households being 5 TWh, but that only 50 percent, or 2.4 TWh are cost-effective to society (see table 6.4).

Table 6.4 Electricity saving potentials in household's being cost-effective to society

\begin{tabular}{lcccc}
\hline Electricity & Consumption & $\begin{array}{c}\text { Maximum saving } \\
\text { potential }\end{array}$ & \multicolumn{2}{c}{$\begin{array}{c}\text { Electricity saving potential being } \\
\text { attractive to society }\end{array}$} \\
\hline TWh & 1.60 & percent & percent & TWh \\
\hline Lighting & 0.58 & 75 & 30 & 0.56 \\
Pumps & 1.98 & 30 & 35 & 0.20 \\
Cooling/freezing & 0.28 & 80 & 15 & 0.30 \\
IT \& electronics & 0.83 & 50 & 40 & 0.11 \\
Other appliances & 0.94 & 65 & 25 & 0.21 \\
Cooking & 1.41 & 70 & 30 & 0.28 \\
Washing appliances & 0.85 & 65 & 35 & 0.49 \\
Television etc. & 8.46 & - & 30 & 0.25 \\
Total & & & 28 & 2.41 \\
\hline
\end{tabular}

Source: DEA (2004), Birch \& Krogboe (2004)

The corresponding length of pay-back period to users for electricity saving measures attractive to society is $1.5-3$ years. The potential assessed to be attractive to the society (2.4 TWh) is only about half of the technical saving potential assessed by Birch \& Krogboe (2004), that would be attractive to the user, i.e., with pay-back periods of the user lower than 4 years (see table 6.5).

Table 6.5 Technical electricity saving potential by residential sector being attractive to users

\begin{tabular}{lll}
\hline & $\begin{array}{l}\text { Saving Potential on short term. in } \\
\text { TWh }\end{array}$ & $\begin{array}{l}\text { Saving Potential on longer-term } \\
\text { (up to 2015) in TWh }\end{array}$ \\
\hline Lighting & 0.56 & 0.64 \\
Cooling/freezing & 0.10 & 0.49 \\
Pumps & 0.14 & 0.29 \\
Other appliances & 0.63 & 2.16 \\
Total & 1.44 & 3.58 \\
\hline
\end{tabular}

Source: Birch \& Krogboe (2004)

The methodology used in Birch \& Krogboe (2004) allows summing up the short term and the long term saving potentials. Accordingly, the overall technical electricity saving potential for the residential sector up to 2015 is estimated to be 5 TWh. 


\subsubsection{Energy savings in public buildings}

The energy saving potential in public sector buildings was studied by the Technical University of Denmark (DTU) in 2008 (Tommerup and Laustsen, 2008) and by Birch \& Krogboe (2004).

Tommerup and Laustsen (2008) studies cost effective energy saving potentials in existing public buildings in a long-term perspective (30 years). The energy saving potential being cost effective to users is estimated to be 1.0 TWh electricity saving per year (or 72 percent of electricity demand) and 3.4 TWh heat saving per year (or 75 percent of heat demand), in total $4.4 \mathrm{TWh} /$ year. The potential being attractive to users is assessed in the report based on Costs of Conserved Energy, CCE ${ }^{21}$, compared with energy prices, where CCE should be less than related energy price in order for the saving to be attractive for users.

Birch \& Krogboe (2004) look at saving potentials being cost effective to users on short term (with BAT) and on the longer term (up to 2015 with new technologies assumed to become available). In total, the short term and long term electricity saving potential is assessed to be $1.6 \mathrm{TWh}$ and the total heat saving potential is estimated to be 2.9 TWh. Accordingly, the overall technical energy saving potential being attractive to users is estimated to be 4.5 TWh for the public sector (see table 6.6).

Accordingly, Tommerup and Laustsen (2008) and Birch \& Krogboe (2004) largely agree on an energy saving potential at 4.5 TWh. However, many of the measures that would be attractive to the users to implement are not attractive to society (assuming calculation rate at 6 percent as with the analysis made by DEA). In terms of energy savings being cost effective to users, the total energy saving potential in public buildings is estimated by Danish Energy Agency (2004) to be 2.6 TWh/year.

Table 6.6 Technical energy saving potential by public sector being attractive to users

\begin{tabular}{lcc}
\hline & Saving Potential on short term. in TJ & $\begin{array}{l}\text { Saving Potential on longer-term } \\
\text { (up to 2015) in TJ }\end{array}$ \\
\hline Lighting & 0.28 & 0.39 \\
Cooling/freezing & 0.02 & 0.02 \\
Electric motors & 0.03 & 0.03 \\
Ventilation & 0.12 & 0.08 \\
Pumps & 0.03 & 0.07 \\
Other appliances & 0.24 & 0.28 \\
All electrical appliances & 0.71 & 0.87 \\
Hot tap water & 0.16 & 0.19 \\
Windows & 0.33 & 0.30 \\
Roof & 0.07 & 0.15 \\
Wall & 0.31 & 0.48 \\
Floor & 0.10 & 0.22 \\
Ventilation & 0.25 & 0.31 \\
Total heat & 1.22 & 1.65 \\
\hline
\end{tabular}

Source: Birch \& Krogboe, 2004

\footnotetext{
${ }^{21}$ CCE or Cost of Saved Energy, CSE, i.e. the price of saving one kWh, taking into consideration life time and financial/investment cost.
} 


\subsection{Finland}

The energy savings potential of the Finnish building stock has been assessed by the Technical Research Center (VTT) as a part of the preparation of the national energy and climate strategy, (Tuomaala, 2008). The potentials are calculated as one conservative and one optimistic estimate (see table 6.7). Differences between the conservative and optimistic scenarios are amongst other different assumptions regarding building standards. In the conservative scenario the building standard are low energy buildings, implying a 50 percent reduction in heating demand compared to conventional energy consumption levels in 2003. In the optimistic scenario the building standard are passive houses, with heating demand in detached dwellings of $25 \mathrm{kWh} / \mathrm{m}^{2}$, in apartments $15 \mathrm{kWh} / \mathrm{m}^{2}$, and in service buildings $9 \mathrm{kWh} / \mathrm{m}^{2}$.

Table 6.7 The savings potential in heating energy, TWh (percent)

\begin{tabular}{|c|c|c|c|c|}
\hline \multirow[t]{2}{*}{ Action /Technology } & \multicolumn{2}{|c|}{ Conservative } & \multicolumn{2}{|c|}{ Optimistic } \\
\hline & 2020 & 2050 & 2020 & 2050 \\
\hline $\begin{array}{l}\text { Energy consumption baseline } \\
\text { ( } 2003 \text { regulations) }\end{array}$ & 65 & 56 & 65 & 56 \\
\hline \multicolumn{5}{|c|}{ Estimate on the savings potential (TWh/year) New Buildings } \\
\hline $\begin{array}{l}\text { Tightening building regulations } \\
\text { (-30 percent in 2010) }\end{array}$ & $2.7(-4 \%)$ & $8.8(-16 \%)$ & $2.7(-4 \%)$ & $8.8(-16 \%)$ \\
\hline Building standards ${ }^{1}$ & $1.4(-2 \%)$ & $3.7(-7 \%)$ & $6.3(-10 \%)$ & $19.2(-34 \%)$ \\
\hline \multicolumn{5}{|c|}{ Estimate on the savings potential (TWh/a) Existing buildings } \\
\hline $\begin{array}{l}\text { Improvement of the energy efficiency of } \\
\text { building shell }\end{array}$ & $3.5(-5 \%)$ & $3.9(-7 \%)$ & $5.7(-9 \%)$ & $6.4(-11 \%)$ \\
\hline $\begin{array}{l}\text { Improvement of the energy efficiency of } \\
\text { building service systems }\end{array}$ & $4.4(-7 \%)$ & $4.9(-9 \%)$ & $7.2(-11 \%)$ & $8.1(-14 \%)$ \\
\hline Energy savings potential total & $12(-18 \%)$ & $21.3(-38 \%)$ & $21.9(-34 \%)$ & $42.5(-76 \%)$ \\
\hline $\begin{array}{l}\text { Energy consumption after all measures } \\
\text { in use }\end{array}$ & 53 & 34.7 & 42.1 & 13.5 \\
\hline
\end{tabular}

Source. VTT (Technical Research Center of Finland)

Impact of energy assistance - a specific study

Heljo et al. (2005) made a rough estimation of the impacts of energy assistances (subsidies to support the renewal of heating systems and other investments aimed at increasing energy efficiency in the housing sector) on GHG emission levels. The estimate is based on the following assumptions:

- Subsidies to apartment houses and terraced dwellings 2003-2012: 15 million $€$ /year of which 11.25 million $€$ is used for apartment buildings

- Subsidies to detached dwellings 2005 - 2012: 10 million $€$ /year.

- 50 percent of the supported projects are additional repairs and additional savings. 
Based on the given assumptions, the gained savings would be approximately 0.5 percent annually by 2010 and 0.4 percent reduction in $\mathrm{CO}_{2}$ equivalents.

\subsection{Norway}

Energirådet (2008) found that if Norway, as-in the EU, aims for an increased energy efficiency of 20 percent toward 2020 of current stationary energy consumption of $180 \mathrm{TWh}$, the target would be as much as 36 TWh. Using the Norwegian standard for cost benefit analysis, this target could generate social benefits of 250 billion Norwegian kroner. For the building sector alone, the equivalent target is 16 TWh. Bellona and Siemens (2007b) identifies potential energy efficiency in Norwegian buildings to be 15 percent, or 8.4 TWh (4.7 TWh for dwellings and 3.7 TWh for industrial/commercial buildings). Investments of 52.4 billion Norwegian kroner are necessary to achieve the energy efficiency targets, with 12.5 billion kroner in the industrial/commercial sector and 39.9 billion kroner for households. The total pay back time for investments is 8.9 years for households and 4.8 years for industrial buildings, and for industrial buildings the "project" would have an internal rate of return of 20 percent.

A projection of Norwegian energy use towards 2020, based on the MARKAL model ${ }^{22}$ predicts a total efficiency potential of 12.7 TWh in 2005, corresponding to 8.5 percent of total energy use (Espegren et al., 2005). This potential increases to almost 19 TWh in 2020. The Norwegian Low energy programme (see chapter 4) states that it is possible to realise savings of 5-7 TWh in the building sector on a longer term given that major barriers are removed.

Heat pumps

Vista Analyse (2006) estimate that heat pumps may provide the household sector with 9.6 to 14 TWh up to 2020, leading to a saving of 6.7-9.8 TWh. The wide range reflects different views on heat pumps. The low estimate reflects opinions on heat pumps as they were in 2005, with a rather low market penetration, while the higher option reflects people looking more optimistically on heat pumps. Since 2005 there has been a substantial increase in the number of heat pumps in Norway, and hence the future development is more likely nearer the higher estimate.

Currently, it is uncertain how large the heat pumps market share will be in the future and what the net effect on total consumption will be. The net effect is partly dependent on what type of heat pump is installed, their

\footnotetext{
${ }^{22}$ MARKAL is a generic model used to estimate the development, over a period of 40 to 50 years, of a specific energy system at the national, regional, state or province, or community level. The model is developed in a cooperative multinational project by the Energy Technology Systems Analysis Programme (ETSAP) of the International Energy Agency.
} 
actual efficiency (energy contributions) and whether they will be used for cooling in the summer. If the use of heat pumps for cooling increases significantly, the total effect can be unchanged or even an increase in total electricity consumption.

\section{Example of energy efficiency in Norway}

Below we present two simple calculations of energy efficiency potentials in Norway, the first assessing improved insulation based on the above presented potentials for Denmark and the second assessing the impact of new low energy buildings based on an earlier projection of energy demand in Norwegian households.

The general building and construction standards within Norway follow a somewhat similar pattern as the other Scandinavian countries. For example, as-of 2001, roofing and wall insulation thickness was fairly uniform across the countries under review. As shown in figures 6.1 and 6.2 below, the Scandinavian countries are clearly similar in terms of insulation, and other evidence points to similarities in other dimensions as well. From these observations, more detailed energy savings potentials for Norwegian buildings can be estimated from research conducted in Denmark. Note, however, that due to the structural differences within the domestic electricity markets, energy saving potential estimation through proxy analysis is not necessarily an appropriate approach.

Figure 6.1 Insulation thickness, roofs (2001)

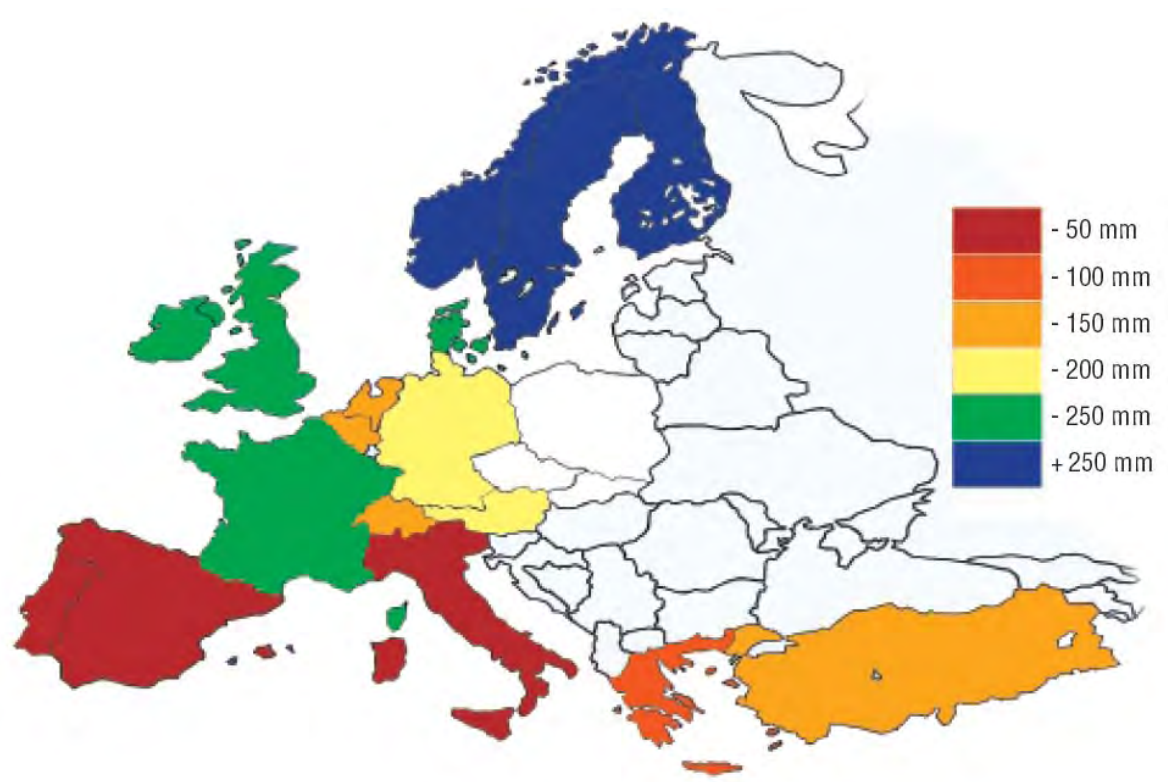

Source: European Insulation Manufacturers Association 


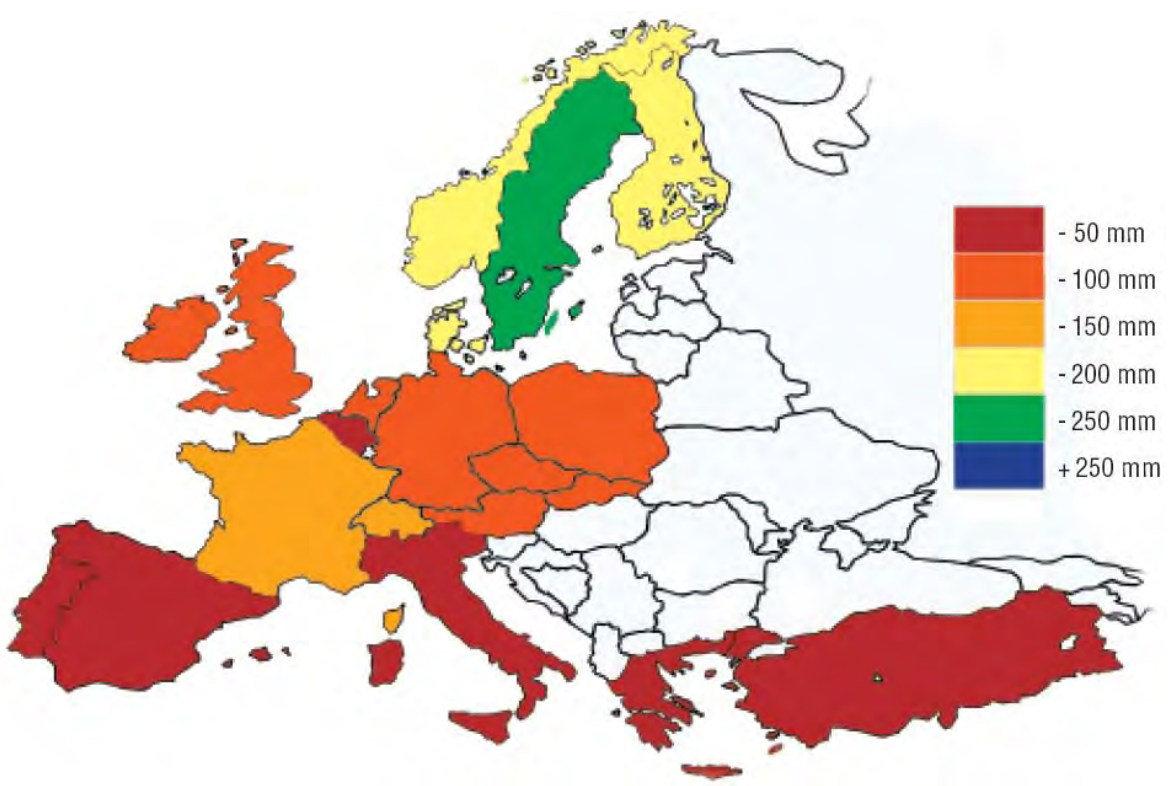

Source: European Insulation Manufacturers Association

Using the above described analyses aimed at Denmark, there is approximately 15 percent energy saving potential from improvements in insulation (including improved windows) in residential housing. ${ }^{23}$ The majority of these energy savings are from higher quality windows (45 percent), with only a 12 to 18 percent energy savings coming from roofing and wall insulation improvements. The 12 percent energy savings from increasing roofing insulation may be a slight overestimation, given the marginally thicker roof insulation in Norway relative to Denmark.

Increased energy efficiency in new buildings will have an impact on the energy demand. Econ Pöyry (2008) presents an estimate of these impacts, based on a continuation of present trends in growth of new households/dwellings and size $\left(\mathrm{m}^{2}\right)$ of these dwellings. These assumptions give a growth in electricity consumptions in households in Norway shown as "Electricity consumption" in figure 6.3. The figure also shows how a 20 percent energy efficiency improvement in new houses, as compared to the existing stock, gradually reduces the electricity consumptions in households. In 2025 the electricity consumption in households is approximately $4 \mathrm{TWh}$ lower, equal to nearly 10 percent net savings.

${ }^{23}$ Assuming that 50 percent of the potential for insulation of roofs, floor and walls are realized and that 100 percent of the potential for renewing windows is utilized. 
Figure 6.3 Example of how energy efficiency in new buildings in Norway can reduce the growth in electricity consumption in Norway

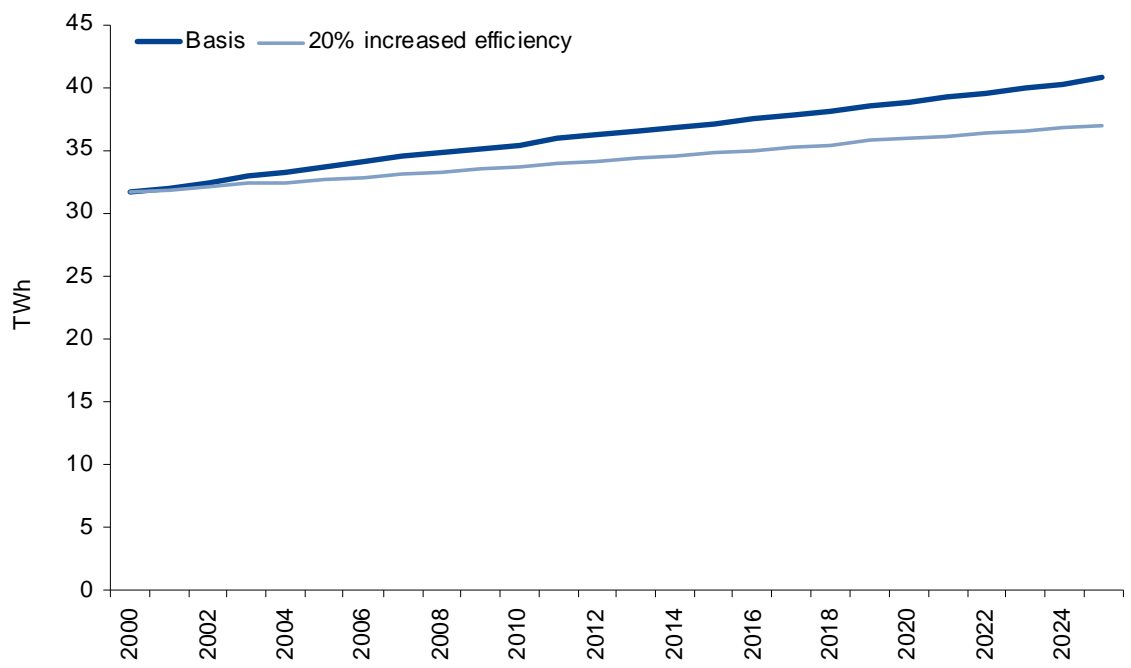

Source: Econ Pöyry

\subsection{Sweden}

The Energy Efficiency Study (SOU, 2008b) outlines the expected effects of measures that has recently been introduced or will be introduced during the period 2005 to 2016. As a result of already formalised measures, it is estimated that for the period 2005 to 2016, the introduction of these will lead to a more efficient final energy consumption of 8.9 TWh in 2016. Table 6.8 provides a full overview of each future measure and the expected effect.

Table 6.8 Expected energy efficiency between 2005 and 2016 as a result of newly introduced measures, (TWh)

\begin{tabular}{llll}
\hline Measure 2005-2016 & Final & Primary & Evaluation method \\
\hline $\begin{array}{l}\text { Future conversion support within small houses, } \\
\text { based on 2005 stock }\end{array}$ & 2.40 & 7.10 & Top-down \\
$\begin{array}{l}\text { Conversion to district heating in premises and } \\
\text { multi apartment building }\end{array}$ & 1.00 & 1.90 & Top-down \\
$\begin{array}{l}\text { Technical procurement } \\
\text { KLIMP, 2005 and onwards }\end{array}$ & 2.27 & 3.40 & Bottom-up \\
OFFROT & 0.05 & 0.06 & Bottom-up \\
Other conversion support, solar heating & 0.60 & 0.80 & Bottom-up \\
Support to energy efficient windows & 0.22 & 0.38 & Bottom-up \\
Boverkets building regulations & 0.06 & 0.12 & Bottom-up \\
District cooling & 2.3 & 2.5 & Bottom-up \\
Combined heat and power & 0 & 1.40 & Bottom-up \\
Total & 0 & 1.80 & Top-down \\
\hline
\end{tabular}

Source: SOU 2008:110 
Chalmers Energy Center (CEC) at Chalmers University of Technology was commissioned by the Energy Efficiency Study to study the future theoretical economic potential for energy efficiency in the building sector (Göransson and Pettersson, 2008). They have calculated the total economical potential for energy efficiency in heating, hot water and installations for current buildings. According to these calculations the potential totals 29 TWh for district heating and fuels and 9 TWh for electricity. Table 6.9 indicates the potential for each building type. The estimations are based on implemented measures such as insulation, electrical installations improvements, window improvements and wall improvements.

Table 6.9 Estimated theoretical economical potential for heating energy, current buildings 2007

\begin{tabular}{lrrrr}
\hline Type of building & \multicolumn{2}{c}{ District heating and fuel } & \multicolumn{2}{c}{ Electricity } \\
& \multicolumn{1}{c}{ Final } & Primary & Final & Primary \\
\hline One and two dwelling buildings & 8,8 & 10,4 & 6,6 & 16,5 \\
Multi dwelling buildings & 10,6 & 12,5 & 0,7 & 1,8 \\
Premises & 9,3 & 11 & 2,2 & 5,5 \\
Sum & 28,7 & 34 & 9,4 & 23,8 \\
\hline
\end{tabular}

Source: SOU 2008:25

Furthermore, Göransson and Pettersson (2008) estimate the theoretical potential for heating and electricity in buildings, if all viable measures are implemented, excluding conversion support, starting in 2005 (see figure 6.4).

Figure 6.4 Theoretical potential for heating and electricity appliances, final energy, TWh (excluding conversion support)

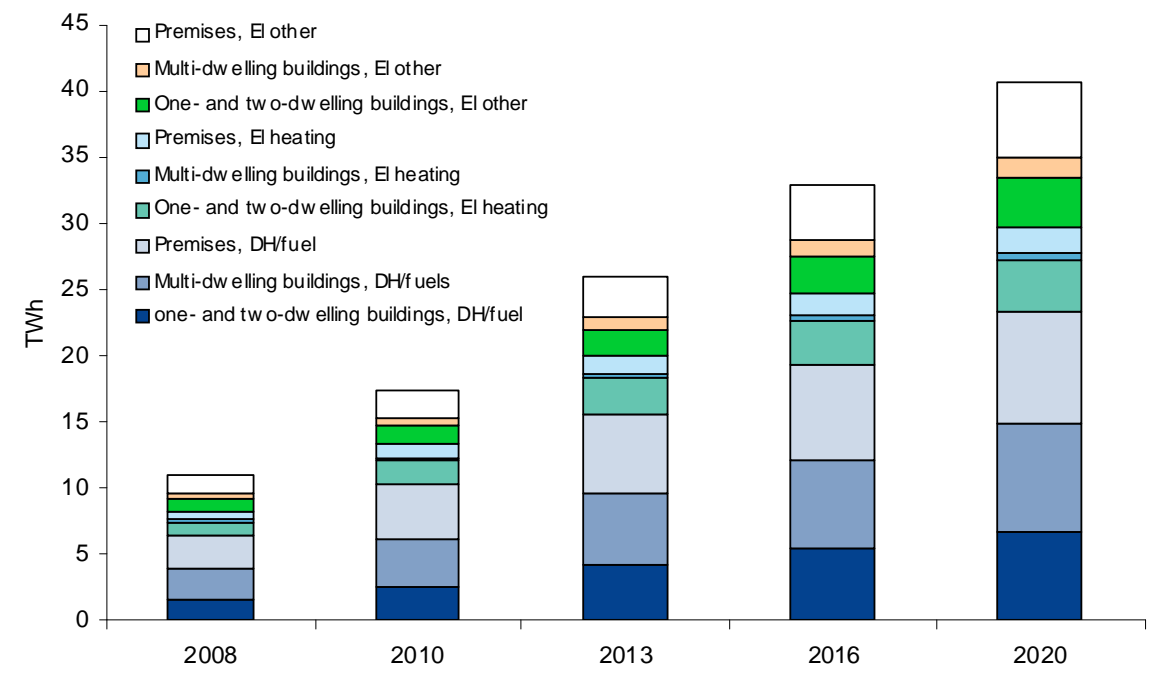


However, it can be argued that the full potential is not likely to be realised and CEC makes more realistic estimation than the one illustrated in the figure above. These estimations are illustrated in figure 6.5.

Figure 6.5 Realistic potential energy for heating and electricity, TWh, final energy

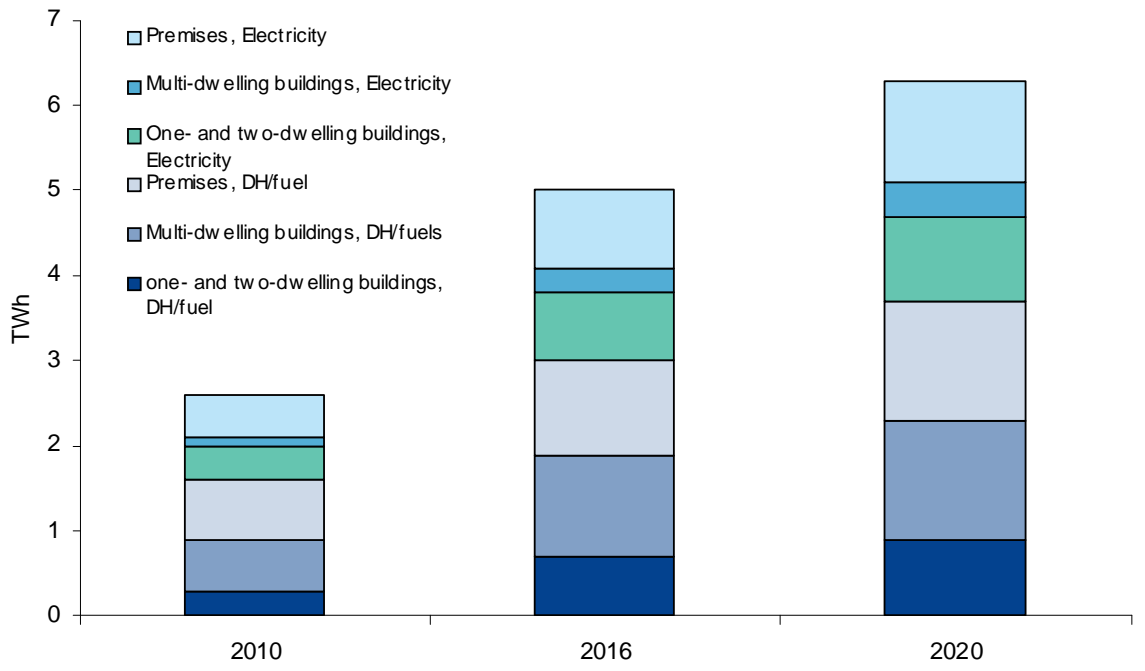

Source: CEC

As mentioned in chapter 5 an assessment of future savings or potentials as a result of energy taxes is presented in SOU (2008c). According to this study the energy savings amount to 6.7 TWh in primary use during 19902016, which means that parts of these savings already have been realised.

The Energy Efficiency Study (SOU, 2008c) reviewed a number of studies aimed at estimating the total energy saving potential through energy efficiency measures. They point out that the qualities of some of these reports vary and that these potentials should be viewed in light of that. However, the Study Team argues that the estimates of the potential for the building sector are more "true" than for other sectors. The identified economic potential for the building sector is 25 TWh in final demand (corresponding to $41 \mathrm{TWh}$ in primary energy), with 14 TWh savings in district heating and fuels and 10 TWh in electricity.

The National Board of Housing, Building and Planning (2005) discusses potentials for energy efficiency in the building sector. They reviewed three studies that had estimated the energy efficiency potential for energy for heating and hotwater, namely the Energy Commission from 1995 (SOU, 1995), Chalmer Energy Center (2005) and K-Konsult (2005). The three studies are summarised in table 6.10, showing that all reach different conclusions due to different assumptions and inputs.

The report also discusses the saving potential for energy within households and operational electricity. However, only reference to the relatively old Energy Commission (SOU, 1995), EK95, is made. EK 95 estimated that there is an untapped potential, in addition to each house- 
holds' spontaneous actions, of 9 TWh. This amount was, however, argued in the same report not to be realistic and the final estimate landed at 5 TWh.

Table 6.10 Review of estimated energy efficiency potential, TWh

\begin{tabular}{|c|c|c|c|c|}
\hline & Technical & $\begin{array}{l}\text { Technicall } \\
\text { Economical }\end{array}$ & $\begin{array}{l}\text { Technicall } \\
\text { Economical } \\
\text { minus spontane- } \\
\text { ous }\end{array}$ & $\begin{array}{l}\text { Investment cost } \\
\text { (Billion Sek/TWh) }\end{array}$ \\
\hline \multicolumn{5}{|l|}{ Attic measures } \\
\hline \multicolumn{5}{|l|}{ EK 95} \\
\hline Housing & & 3,2 & 1,2 & \\
\hline Premises & & 0,5 & 0,2 & \\
\hline Total & & 3,7 & 1,4 & 8 \\
\hline \multicolumn{5}{|l|}{ CEC 05} \\
\hline Small houses & 3 & & & \\
\hline Multi houses & 1,5 & & & \\
\hline Total houses & 4,5 & & & \\
\hline Premises & & 0,5 & & 2,5 \\
\hline \multicolumn{5}{|l|}{ KK 05} \\
\hline Small houses & & 1 & & 10 \\
\hline \multicolumn{5}{|l|}{ Facade measures } \\
\hline EK 95 & & 9,7 & 5,9 & 9 \\
\hline Housing & & 7,7 & 5 & \\
\hline Premises & & 2 & 0,9 & \\
\hline CEC 05 & 11 & 1.5 & & 2.5 \\
\hline Small houses & 7,5 & & & \\
\hline Multi houses & 3,5 & & & \\
\hline Premises & & 1.5 & & 2.5 \\
\hline KK 05 & 3 & & & 8 \\
\hline \multicolumn{5}{|l|}{ Window measures } \\
\hline EK 95 & & 11,3 & 5,3 & \\
\hline Housing & & 7,3 & 2,8 & \\
\hline Premises & & 4 & 2,5 & \\
\hline CEC 05 & 7 & 3 & & 4 \\
\hline Small houses & 4 & & & \\
\hline Multi houses & 3 & & & \\
\hline Premises & & 3 & & 4 \\
\hline KK 05 & & 0.3 & & 8 \\
\hline \multicolumn{5}{|c|}{ Installations measures } \\
\hline EK 95 & & 11,6 & 5,3 & \\
\hline Housing & & 5,6 & 2,4 & 4 \\
\hline Premises & & 6 & 2,9 & \\
\hline CEC 05 & 9 & 6 & & \\
\hline Small houses & 4,5 & & & \\
\hline Multi houses & 4,5 & & & \\
\hline Premises & & 6 & & \\
\hline KK 05 & & 2,9 & & \\
\hline
\end{tabular}

Source: National Board of Housing, Building and Planning

\subsection{The total potential for energy savings}

The performed potential studies all point at more or less substantial potentials to save energy in the building sector. The studies differ in methodologies and assumptions, and can therefore be hard to compare and it is also difficult to transfer the results from one study to other countries. However table 6.11 gives a summary of the above presented potential savings. For some of the countries several potentials have been presented and the below table indicates the more conservative potentials. For Den- 
mark this means the potential benefit for the society, as only that kind of measures would be pursued by the government. Regarding Finland the potentials labelled as conservative potentials are presented here and for Sweden the potentials labelled realistic are presented here.

Table 6.11 Summary of potential savings for each country.

\begin{tabular}{llll}
\hline Country & Technologylmeasure & Sector & TWh/year \\
\hline \multirow{2}{*}{ Denmark } & Heat savings profitable for society & Residential & 12.4 \\
& $\begin{array}{l}\text { Electricity savings profitable for society } \\
\text { Energy savings profitable for society }\end{array}$ & $\begin{array}{l}\text { Residential } \\
\text { Public Buildings }\end{array}$ & 2.4 \\
& Heat savings, conservative & New Buildings & 12.5, up to 2050 \\
Finland & Heat savings, conservative & Existing buildings & 8.8, up to 2050 \\
& Energy savings & Residential & 4.7 \\
Norway & Energy savings & Industrial & 3.7 \\
& Heat and electricity savings & $\begin{array}{l}\text { Realistic potentials, if all } \\
\text { viable measures exclud- }\end{array}$ & 6.3 \\
& & $\begin{array}{l}\text { ing conversion supports } \\
\text { are implemented }\end{array}$ & \\
\hline
\end{tabular}




\section{Measures to use}

The discussion of instruments and potentials above shows that there is a potential for cost-effective energy savings in the building sector in the Nordic countries. What kind of measures to use in order to realise these potentials are partly due to the underlying target (energy savings as such or reduced emissions of greenhouse gasses) and an assessment of potential benefits and costs (or drawbacks) of the individual instruments, like the risk of rebound.

\subsection{Initial considerations}

Our mapping shows that there are already several policies and measures in place that aim to increase energy efficiency, both in general and towards the building sector as such. One might therefore ask if there is a need for additional measures towards the building sector. One argument for this is that a lot of barriers for energy efficiency in this sector have been identified and most likely the present effort on energy efficiency is below what is social optimal.

It is however, important to recognise that there always will exist an energy efficiency gap, meaning that there is a potential for profitable efficiency gains/investments that are not being performed. To what extent the authorities shall use political measures to reduce this gap, is partly a question about whether the barriers causing the gap can be considered a social market failure and partly if the expected gains (reduced energy use and/or $\mathrm{CO}_{2}$ emissions) exceeds the costs of implementing the measure.

When designing measures there are several questions that need to be addressed:

- What is the underlying target; reduced emissions of climate gasses or energy use as such (i.e., security of supply)?

- Should the measures target existing and/or new buildings?

- What kind of building should be affected: residential, commercial and/or public?

- What actors should be targeted: builders (large or small companies), owners and/or users?

Below we discuss these questions, and also suggest measures depending on the answers. 


\subsection{What is the target?}

As discussed in chapter 3 the main rationale for targeting energy efficiency are environmental concerns, and predominately the climate issue, and concerns about energy supplies. Whether or not energy efficiency measures are the best measures to handle these problems is an open question.

If the main concern is the climate issue then it is actually not the energy use that is the problem, but the emissions stemming from the use of fossil energy sources. Targeting energy efficiency might be very indirect and have little effect on emissions of greenhouse gasses. In fact a Swedish study (Brännlund et al., 2007 shows that these emissions might actually increase as a result of an exogenous increase in energy efficiency. Studying the consumption pattern in Sweden they estimate that an increase in energy efficiency in transport and heating of 20 percent gives an increase in $\mathrm{CO}_{2}$ emissions of 5 percent. This is due to altered consumptions patterns, mostly in the form of increased car transport. They also calculate that the $\mathrm{CO}_{2}$ tax must increase by 135 percent in order to keep the $\mathrm{CO}_{2}$ emissions at the initial level. On the other hand, if the energy released by these savings could substitute for more polluting energy sources there might give a positive effect on $\mathrm{CO}_{2}$ emissions. ${ }^{24}$ In order to access these effects in a comprehensive manner one needs to apply integrated energy and economic models.

The climate issue should preferably be handled by $\mathrm{CO}_{2}$ taxes or quota systems that cover all emissions. This would also prevent that energy efficiency gains, and possible $\mathrm{CO}_{2}$ reductions in one sector or use (for instance space heating) being counteracted by increased activity and $\mathrm{CO}_{2}$ emissions elsewhere. But an optimal $\mathrm{CO}_{2}$ tax is not able to handle all the identified barriers in the building sector, and hence there could still be a need to address some of these with more targeted measures.

If the main concern is to secure energy supplies then energy efficiency might be a more direct measure since it is a more direct link between this target and measures. Energy security policies can ensure that the supply meets the demand at all times, and certain measures decreasing the demand can be one way to achieve this.

To promote technological development is also an eligible policy based on the fact that there is a positive externality in R\&D and that firms normally underinvest in these activities. The aim of this study is also to give input to the Nordic countries work related to EUs action plan for environmental technologies (ETAP), which is related to the supposedly positive externalities from $R \& D$. But policies to increase $R \& D$ should generally be neutral, i.e., not favour any particular technology.

${ }^{24}$ For instance, saving electricity in Norway can mean that this electricity can be exported to Europe and substitute for coal fired power plants. 


\subsection{Targeting existing or new buildings?}

When designing measures it is important to distinguish between measures that target existing buildings and those that target new buildings. Targeting new buildings can be important if the authorities want to push technological development in this area, but it will not give any substantial efficiency gains in the short run. In most countries new constructions only constitute 1-2 percent of the building stock annually, and hence it will take a long time before new and more energy efficient buildings affect the total energy use in the building sector. Our example in chapter 5 shows that an average efficiency gain of 20 percent in new residential buildings will give an energy saving of 10 percent in 20 years. This is of course a very stylistic example, but it gives an illustration of the time perspective for promotion of new buildings. At the same time solving the climate problem will require development of new and more efficient technologies, and hence different kind of support (financial or nonfinancial) to promote such development will be essential.

If the target is to reduce energy use in a shorter time frame then it is necessary also to consider energy efficiency in existing buildings, and also to focus behavioural changes in addition to deployment of new technologies.

\subsection{Which buildings and actors to target?}

How to design measures might also depend on if the target group is residential, commercial or public buildings. Residential buildings make up nearly 60 percent of the total building stock in the Nordic countries, and it is probably here one finds the largest potential for increased efficiency. The Danish calculations presented in chapter 6 shows that there is a cost effective potential of 14 TWh in the residential sector until 2015, whereas the corresponding figure for public buildings is $2.4 \mathrm{TWh}$. At the same time targeting residential buildings is probably less steering effective than larger users in commercial and public buildings.

Regardless of what kind of buildings the authorities aim at, the design of the measure has to take into consideration what actors it is most efficient to target:

- New constructions and larger renovations: builders and construction companies are probably the most important target groups. Influencing the energy system as early as possible in the building (or renovating) process will most likely be more cost effective than changing this later in the buildings life cycle.

- Public buildings: the public sector should have an incentive to be in the front, and act as a good example for other actors. 
- Users, i.e., private households and companies: it is the user of the building who ultimately decides the energy use. Efficient energy systems that are not being used or managed properly are most likely inefficient, both for the individual user and the society.

\subsection{Suggested measures}

Below we have listed measures with the aim to overcome some of the barriers for energy efficiency in the building sector. The aim have been to suggest concrete measures, but at the same time all measures have to be adjusted to relevant circumstances in each single country, for instance taking into account already existing measures. Before introducing new measures already existing should be carefully assessed, with the aim of identifying if and why they are not sufficient. It is also important to considerer how other policies and regulations affect energy efficiency. At least for Norway the write-off rules for energy investments are being regarded as a disincentive for such investments. Public support to renewable energy production can also in certain circumstances contradict efforts to save energy. This is the case when such support contributes to lower energy price than the long time marginal costs for new production and when the support is being financed through the state budget and not by the energy users.

All measures suggested implemented should be carefully evaluated ex-ante, ensuring that the benefits exceed the social costs of implementing them i.e. a thorough cost benefit analysis should be performed that amongst other also addresses the rebound issue.. It is also useful to design the measures in such a way that it is possible to evaluate them ex-post.

\subsubsection{Measures aimed at the construction and building phase}

Targeting the building industry is very important, since how the buildings are actually constructed, and what energy system that is installed will form the basis for energy demand for a long time period. It is for instance important to ensure that energy is included in the planning process, and not as something that is taking into consideration after the building has been designed.

Measures towards the building sector should aim at overcoming the identified barriers, such as structural issues, lack competence and financial constraints.

\section{Competence building}

An important barrier for increased use of energy efficient technologies in new building is the lack if knowledge about the possibilities. Competence building in the building industry is therefore essential. This includes for 
instance incorporation of energy aspects in vocational training in secondary upper school, and in architectural education. Providing supplementary training for all levels in the building sector can also be an important measure.

\section{Regulatory measures}

Regulations are normally an important driver for environmental technologies, and this will probably also hold for the building sector. Using proactive building codes and revising them regularly, will likely increase both the demand for and supply of efficient solutions. Both for Denmark and Norway it has been announced that the building codes will be revides every fifth year. At the same time it can be difficult to have too proactive building codes, as they should apply to all actors in the sector. One way to deal with this is to enjoin the codes regularly and as early as possible announce the requirements in the new and stricter regulations, giving the industry time to adopt to new requirements.

Stricter building codes will have the largest effect if they are controlled in a reliable manner. Mandatory energy inspections by independent and authorised bodies could be a measure to ensure control. At least for Norway the lack of control that the requirements on energy use in existing building codes are actually met has been identified as a possible explanation to the fact that energy use in new office buildings actually are much higher than the requirements in valid building codes. However, external control can be rather costly and should probably be restricted to larger buildings and with rather large time intervals (like each $10^{\text {th }}$ year).

\section{Cooperative measures}

Networking and voluntary agreements between the industry and the authorities can also be viable measures. These network and cooperation could be used for instance to facilitate and/or promote smart building concepts, i.e. integrating different actors in a building process and could hence help build down structural barriers. But for voluntary agreements to be effective there has to be either a "hidden" threat, like the possibilities of tougher regulations, or some benefits that only apply to members of the agreement ${ }^{25}$.

The last years focus on climate has already spurred several initiatives where the industry cooperates, often also engaging the authorities, to find more sustainable solutions. Before initiating new cooperation the ongoing should be carefully examined, and it would probably be a good idea to strengthen them before starting a new.

\footnotetext{
${ }^{25}$ Both Norway and Sweden has a voluntary agreement for energy savings in the energy intensive industry, where companies participating are entitled to lower energy taxes.
} 
Financial support

Financial support to energy audits and/or investments in new technologies might also be necessary, at least for a short time in order to introduce new technologies in the market. Support to demonstration projects is also included in this category. The support can either be investment grants, tax deductions or different forms of soft loans. For financial support there are several considerations to take, like additionality and administrative costs (both for the authorities and the receiver). To secure strict additionality often impedes high administrative cost, so there is a trade off between these.

\subsubsection{End users}

The users should mainly be exposed to the "right" energy price through taxation or other market based instruments (for instance white certificates). If the right energy price implies increased end-user prices the authorities can provide information about the possibilities to save energy as this could make the increase more socially acceptable. Information and public advice that is either provided for free or at a low cost can also be used to reduce informational barriers, inertia and implementing costs (i.e. other costs than the financial).

Obligations for energy suppliers to provide households with opportunities to reduce their energy consumption can also be viable instruments. Examples of such instruments include the Danish agreement between the Government and energy distribution companies in electricity, gas and petroleum on quantitative energy saving targets and the EEC/CERT instrument ${ }^{26}$ in the UK.

Financial support to energy efficient investments should be used with great care in this sector, since there is a rather high risk of rebound if the savings become "too cheap". If financial support is given this should be time limited, like the conversion supports in Sweden, to promote a faster transition to a new technology.

The public sector should possibly have a pioneering role when it comes to energy use, partly based on a need "to order one's own house" before demanding that the private sector does so. It could also be argued that the public sector should take a larger responsibility for social aspects (like the environment) than can be expected from private actors. This could for instance be done by demanding that public builders and owners include energy efficiency in procurement processes, both when building or renovating and when renting premises. At the same time the public sector often has tight budget restrictions, and the public accounting sys-

\footnotetext{
${ }^{26}$ These are so called energy suppliers obligations. The Energy Efficiency Commitment (EEC) was introduced in 2002. The first round of this instrument, 2002-2005, had an objective of $62 \mathrm{TWh}$, but this was reached by a wide margin (nearly 70 TWh). From April 2008 EEC was replaced by the CERT (Carbon Emission Reducing Target), where the goal instead is associated with reduced $\mathrm{CO}_{2}$ emissions and where it is possible also to get support for market transformation.
} 
tem (with one year budgets) can also be a barrier for energy efficient investments.

\subsubsection{Overcoming different incentives}

To overcome the split incentive barrier measures that affect both the supply and demand side are necessary, but with a focus on creating a demand for energy efficient technologies. OECD/IEA (2007) stresses that there is a need for comprehensive policy packages to address these problems, affecting the design of contracts, the regulation of energy use and the information available. Several of the above mentioned measures will also help in overcoming this barrier, if they are able to focus the attention on energy among all actors. Mandatory energy labelling of buildings, as required in EPBD, might induce a demand for buildings with lower energy use, and also make builders and owners focus on energy in a life cycle perspective, not only in the building phase. But if they actually will affect energy efficiency is partly a question about energy prices. If the energy costs are an important part of the total operational costs (including for instance rent and mortgages) then energy labelling can be effective, but otherwise it is likely to have less effect. A parallel to this is mandatory labelling of household equipment like refrigerators. In Norway, where the electricity prices are lower than in the other Nordic countries, this labelling has had only minor effects. Equipment with the highest rating, $\mathrm{A}++$, are not being sold in Norway because they are too expensive in relation to energy prices and thus not profitable for the users.

In order to be effective the energy labelling must also be credible, and some sort of control mechanism should be present. As mentioned above it is also important that this control not become too costly. For private dwellings the labelling could be based on the owners own assessment, but complemented with inspections on a more or less regular basis. For public and commercial buildings, at least over a certain size, the labelling should preferably be based on mandatory energy audits performed by independent and authorised bodies.

Part of the split incentive barriers is due to badly designed contracts between the owner and the user of a building with regards to energy. The contract should be designed so that all parties involved in energy use decisions actually face the right price signals. There might also be a need for contractual arrangements that ensures that the party investing in energy saving equipment actually gets paid through the savings at the energy user side. The design of these contracts is mainly a task for the market actors, but the authorities can assist by providing information and contract templates. 



\section{References}

Alfredsson E.C. (2004): “Green” consumption - no solution for clime change, Energy, Vol. 29, No4, 513-524.

Allan G., N. Hanley, P. McGregor, K. Swales, and K. Turner (2007): The impact of increased efficieny in the industrial use of energy: A computable general equilibrium analysis for the United Kingdom, Energy Economics, Vol. 26, Iss. 1 27-50.

Bellona and Siemens AS (2007a): Energieffektivisering i norske bygg, Barrierestudien (Energy efficiency in Norwegian buildings, the barrier study), https://www.nwe.siemens.com /norway/internet/no/campaign/ Energieffektivisering/ Documents/ Barrierestudien.pdf.

Bellona and Siemens AS (2007b): Energieffektiviseringsrapporten (The energy efficiency report), https://www. nwe.siemens.com/norway/internet/no/ campaign/Energieffektivisering/ Documents/Energieffektiviseringsrapporten.pdf.

Birch \& Krogboe (2004): Potentialevurdering, Energibesparelser i husholdninger, erhverv og offentlig sektor, Sammenfatning af eksisterende materiale og analyser (Assessment of potentials, Energy savings in households, industries and public sector, summary of existing material and analyses), Birch \& Krogboe AS for the Danish Energy Agency.

Bjørnstad, E., J. Grande, R. Sand and C. Wendelborg (2005): Evaluering av tilskuddsordningen til varmepumper, pelletskaminer og styringssystem (Evaluation of the support scheme to heat pumps, pellet stoves and steering systems), NTF-Report 2005:2, NordTrøndelagsforskning, Steinkjer.

Brännlund R., T. Ghalwash, and J. Nordström (2007): Increased energy efficiency and the rebound effect: Effects on consumptions and emissions, Energy Economics, Vol. 29, Iss 1, 1-17.

Cambridge Centre for Climate Change Mitigation Research (2006): The macro-economic rebound effect and the UK economy. Report to Defra. Cambridge.

Chalmer Energy Center (2005): Åtgärder för energieffektivisering i bebyggelsen (Measures for energy efficiency in buildings), CEC Report 2005:1, Gothenburg.

Danish Energy Agency (2004): Faglig baggrundsrapport, Handlingsplan for en fornyet indsats, Energibesparelser og marked (Technical background report, Action plan for renew effort, Energy savings and market), Copenhagen.

Danish Energy Agency (2008), Energipolitisk redegørelse 2008, Klima- og energiministerens redegørelse i henhold til Lov om energipolitiske foranstaltninger (Energy policy statement 2008, the Minister of climate and energy's statement according to the Act on energy policy arrangement).

Danish Ministry of Economic and business affairs (2008): Vækst, klima og konkurrenceevne (Growth, climate and competitiveness), Økonomisk Tema no7.

Dinan T.M. and D. Trumble (1989): Temperature takeback in the Hood River Conservation Project, Energy and Buildings, Vol 13, Iss 1, 39-50.

Dubin J.A., A.K. Miedema and R.V. Chandran (1986): Price effects of energy-efficient technologies: a study of residential demand for heating and cooling, Rand Journal of Economics, Vol 17, No 3, 310.

ECON (2004a): Evaluering av program for energiledelse i bygg (Evaluation of the program for energy leadership in buildings), Econ Report 2004-056. Oslo.

Econ Pöyry (2007a): Evaluering av program for bolig, bygg og anlegg (Evaluation of the program for energy efficincy in buildings), Econ Pöyry Report 2007-133, Oslo.

Econ Pöyry (2007b): Energibærere i Norge (Energy carriers in Norway), Econ Pöyry Report 2007-083, Oslo. 
Econ Pöyry (2007c): Energiloven og energieffektivisering (The Energy Act and energy efficiency), Econ Pöyry Report 2007-071, Oslo.

Econ Pöyry (2007d): Uvärdering av stödet till konvertering (Assessment of the conversion support), Econ Pöyry report 2007-105, Oslo.

Econ Pöyry (2008): Fremtidig utvikling i kraftforbruket (Future development in power demand), Econ Pöyry, Memo 2008-014, Oslo.

Emtairah, T., N. Tojo, Å. Thidell, V. Rozite and M. Hayes (2008): The challenges of energy efficiency innovations in the Nordic building sector, TemaNord 2008:566, Nordic Council of Ministers, Copenhagen.

Energirådet (2008): Energieffektivisering (Energy efficiency), Utredning 21.11.2008,

http://www.regjeringen.no/upload/OE D/Energiraadets_rapport_energieffekti visering\%20211108.pdf .

Enova (2008): Enovas byggstatistikk 2007 (Enovas building statistics 2007), Trondheim.

Espegren, K. A., E. Rosenberg and A. Fidje (2005): Energibruksutvikling 1980-2020 : historisk utvikling, drivkrefter og fremskrivninger (Development of energy use 1980-2020, historical development, drivers and projections), Report IFE/KR/E-2005/006, IFE, Kjeller.

Feilberg, N., B. Grinden, P.C. Næasje, M. Thyholt, B.J. Wachenfeldt and O. Wolfgang (2007): Varmemarkedets utvikling og betydning for fleksibiliteten i energiforsyningen (The development of the heating market and its effect for a flexible energy system), Sintef Energy Research, Trondheim.

Göransson A, och Pettersson B (2008): Energieffektiviseringspotential i bostäder och lokaler, Med fokus på effektiviseringsåtgärder $200 \tilde{5} 2016$ (The potential for energy efficincy in dwellings and premises, with focus on measures 2005-2016), Chalmers EnergiCentrum, Report CEC 2008:3, Gothenburg.

Haas R., Biermayr P., 2000. The rebound effect for space heating: empirical evidence from Austria, Energy Policy, Vol. 28, Iss. 6-7, 403-410.

Halvorsen, B., B.M. Larsen and R. Nesbakken (2005): Norske hushold- ningers energiforbruk til stasjonære formål 1960-2003, en diskusjon basert på noen analyser i Statistisk sentralbyrå (Norwegian households energy use for stationary purposes 1960-2003, a discussion based on some analyses at Statistics Norway) Report 2005/37, Statistics Norway, Oslo.

Halvorsen, B., B.M. Larsen and R. Nesbakken. (2007): Simulering av husholdningenes elektrisitetsforbruk (Simulation of electricity use in households), Report 7/2007, Statistics Norway, Oslo.

Heljo J, Nippala E \& Nuutila H (2005): Energy consumption and CO2-eq. emissions of buildings in Finland, Institute of Construction economics, Report 2005:4, Tampere University of Technology.

Herring, H. and R. Roy (2007): Technological innovation, energy efficient design and the rebound effect, Technovation 27 (2007), p 194-203.

Hirst E., White D., Goeltz R., (1983): Indoor temperature changes in retrofit homes, Energy, Vol 10, No. 7, 861-870.

K-Konsult (2005): Uppvärmning av småhus (Heating of small dwellings), appendix to ER 2005:27, Swedish Energy Agency; Eskilstuna.

Milne G., Boardman. B., 2000. Making cold homes warmer: the effect of energy efficiency improvements in low income homes, Energy Policy, Vol. 28, Iss. 6-7, 411-424.

Mizobuchi, K. (2008): An empirical study on the rebound effect considering capital costs, Energy Economics 30 (2008) 2486-2516.

Nässén, J. (2007): Energy efficiency Trends, determinants, trade-offs and rebound effects with examples from Swedish housing. Chalmers University of Technology. Doctoral thesis; 2682, Gothenburg.

National Board of Housing, Building and Planning (2005): Piska och Morot Bovekets utredning om styrmedel för energieffektivisering i byggnader (Whip and carrot - The National Board of Housing, Building and Planning assessment on measures for energy efficiency in buildings), Karlskrona.

National Board of Housing, Building and Planning (2007): Mindre olja bättre miljö, men till vilket pris? (Less oil 
better environment, but to what price?), Karlskrona.

NOU (2007): En vurdering av særavgiftene (An assessment of exice duties), Official Norwegian Report 2007:8.

OECD/IEA (2007): Mind the Gap, Quantifying Principal-Agent Problems in Energy Efficiency, International Energy Agency, Paris.

Ryghaug, M. and K. Sørensen (2009): How energy efficiency fails in the building industry, Energy Policy 37(2009), p 984-991.

SOU (1995): Energikommisionen (The Energy Commission), Official Swedish Report (SOU) 1995:139.

SOU (2008a): Svensk Klimatpolitik. Betänkande av Klimatberedningen (Swedish climate policy, Consideration from the Climate Working Committee), Official Swedish Report 2008:24.

SOU (2008b): Vägen till ett energieffektivare Sverige (The road to a more energy efficient Sweden), Official Swedish Report 2008:110.

SOU (2008c): Ett energieffektivare Sverige (A more energy efficient Sweden), Official Swedish Report 2008:25.

Statistics Denmark (2008): Statistical Yearbook 2008 - Construction and Housing, (www.dst.dk/pubpdf/ 12429/10con), Copenhagen.

Statistics Finland (2008): Bostadshushåll og bostadsforhållanden 2007 (Households and housing conditions), Statistiskcentralen, Helsinki.

Statistics Norway (2005): Levekårsundersøkelsen 2004. Boforhold, Stadig færre bor trangt i Norge (Study of living conditions 2004, Housing conditions, increasingly less lives in cramped quarters), www.ssb.no, published June 14.

Statistics Norway (2008a): Bygningsmassen 2008, Flest hytter i Oppland og Buskerud (The building stock 2008, most cottages in Oppland and Buskerud), www.ssb.no, published March 03.

Statistics Norway (2008b). Energiforbruk per husholdning, 2006, Fortsatt lavt strømforbruk i husholdninger (Energy use in households 2006, Still low electricity use in households), www.ssb.no, published April 28.
Statistics Norway (2008c): Norsk mediabarometer 2007: Økt internett-bruk, færre avislesere (Norwegian media barometer 2007: Increased use of internet, less newspaper readers), www.ssb.no, Published April 03.

Statistics Sweden (2009a): Bostads- och byggnadsstatistisk årsbok 2009 (Yearbook of Housing and Building Statistics 2009), Official Statistics of Sweden, Stockholm.

Statistics Sweden (2009b): Energistatistik för småhus, flerbostadshus och lokaler 2007 (Summary of energy statistics for dwellings and nonresidential premises for 2007), ES 2009:06. Stockholm.

Swedish Energy Agency (2006): Effektivare energianvändning.En uppföljning av måluppfyllelse avseende EGdirektivet om effektivare slutanvändning av energi och om energitjänster mellan åren 1991 till 2004. (More efficient energy use, a follow up of the targets related to the EU Directive on efficient end use of energy) ER 2006:32, Eskilstuna.

Swedish Energy Agency (2007): Effektivare energianvändning (More efficient energy use), ER 2007:21, Eskilstuna.

Swedish Energy Agency, 2008: Elcertifikatsystemet 2008 (The green certificates 2008), ET 2008:07, Eskilstuna.

Swedish Environmental Protection Agency (2004): Fortsatt grön skatteväxling - förslag till utformning (Continued green taxation - suggestions on design), Report 5390, Naturvårsverket, Stockholm.

Swedish Environmental Protection Agency (2008): Effekter av investeringsprogrammen LIP och Klimp (Effects of the investment programs LIP and Klimp), Report 5861, Naturvårdsverket, Stockholm.

Swedish Environmental Protection Agency, 2006): Ekonomiska styrmedel i miljöpolitiken (Economic measures in the environmental policy), Report from the Environmental Protection Agency and the Energy Agency.

Tommerup, H. and J.B. Laustsen (2008): Energibesparelser i bygninger i den offentlige sektor (Energy Saving Potential in public buildings), Report BYG·DTU R-184, Technical University of Denmark. 
Tuomaala, P. (2008): Teknologiapolut 2050 Rakennussektori (Technology Pathways 2050 - Construction Sector), presentation 12.02.2008, VTT (Technical Research Center of Finland)

Unander, F. I. Ettestøl, M. Ting and L. Schipper et al. (2004): Residential energy use: an international perspective on long-term trends in Denmark, Norway and Sweden, Energy Policy 32/12 (2004).
Vista Analyse (2006): Framskrivning av varmepumpenes bidrag til det norske energisystemet, (Projection of the contribution from heat pumps in the Norwegian energy system), Oslo.

Wittchen, K.B (2004): Vurdering av potentialet for varmebesparelser i eksisterende boliger (Assessment of Heat Savings Potential in existing residential buildings), By og Byg dokumentario 057, Danish Building Research Institute. 


\section{Sammendrag}

\section{Energieffektivitet i byggesektoren}

For å nå en bærekraftig utvikling er det viktig å utvikle og ta i bruk teknologier som har mindre påvirkning på miljøet. Teknologi som bidrar til lavere energibruk er en viktig del av dette. Energiforbruket i bygninger, inkludert energi brukt i byggefasen, antas for å utgjøre omtrant 40 prosent av stasjonært energiforbruk. Økt energieffektivitet i denne sektoren kan derfor ha en stor effekt på totalt energiforbruk, og samtidig fremme bærekraft og måloppnåelse hva gjelder reduserte utslipp av klimagasser. Flere studier har imidlertid identifisert vesentlige barrierer som hindrer øt energieffektivisering i denne sektoren. Barrierene er relatert til hvordan sektoren er organisert, at den er følsom for konjunkturer og mangel på informasjon om mulighetene for redusert energiforbruk. Basert på et behov for å utvikle mer bærekraftige bygninger har Nordisk Ministerråds arbeidsgrupper for integrert produktpolitikk og miljø og økonomi bedt om en utredning av økonomiske aspekter ved energieffektivisering i den nordiske byggesektoren.

Prosjektets kortsiktige mål har vært å gi innsikt i og forståelse for hvordan virkemidler for økt energieffektivitet kan bidra til redusert miljøpåvirkning og hvilke virkemidler som er mest effektive for å fremme ny teknologi i byggesektoren. Et annet mål er å gi innspill til de nordiske landene i deres arbeid med å utvikle EUs handlingsplan for miljøteknologi (ETAP). Resultatet kan også brukes i landenes oppfølging av nasjonale klimamål. Rapporten omhandler Danmark, Finland, Norge og Sverige.

\section{Konklusjoner}

Den overgripende konklusjonen fra analysen er at det fines et økonomisk potensial for økt energieffektivisering I den nordiske byggesektoren. Hvor stort dette potensialet er er imidlertid vanskelig å fastslå, blant annet grunnet manglende statistikk over energibruk i bygninger. Samtidig er det flere barrierer som hindrer bruken av mer effektive løsninger, og foreløpig har ikke eksisterende politikk og virkemidler lyktes helt med å bygge ned disse barrierene. Eksisterende politikk for energieffektivisering er bygget på behovet for å redusere utslippen av klimagasser og nødvendigheten av en sikker energiforsyning, men det er primært for det sistnevnte som energieffektivisering er et direkte og hensiktmessig virkemiddel. $\AA$ fremme energieffektivisering for å redusere utslippen av klimagasser må gjøres med forsiktighet, ettersom virkemidlene kan utløse store rebound- 
effekter som til syvende og sist kan bety at utslippene kun reduseres marginalt eller ikke overhode, eller endog øker.

\section{Klima og energiforsyningen driver politikken}

Det er flere grunner for offentlig inngripen for å fremme økt energieffektivisering. Disse grunnene består av ulike former for markedssvikt om eksisterer uavhengig av politiske mål, for eksempel forekomst av eksternaliteter, markedsmakt og asymmetrisk informasjon. Andre grunner er basert på politiske mål, som reduserte utslipp av klimagasser og en sikker og pålitelig energiforsyning. Flere av de energipolitiske målene og virkemidlene i de nordiske landene er avledet av mål satt innenfor EU. EUs energipolitiske mål inngår I EUs klimamål og det så kalte "20 2020 by 2020” mallet (en reduksjon av CO2-utslippen med 20 prosent innen 2020, en økning $\mathrm{i}$ andelen fornybar energi til 20 prosent innen 2020 og en økning i energieffektiviteten med 20 prosent innen 2020). Energipolitikken i de landene som inngår i analysen er basert på klimaproblemet, viktigheten av å sikre energiforsyningen og å sikre et konkurransekraftig marked med "overkommelige” priser. Virkemidler for økt energieffektivisering er som regel en del av løsningen på de to første utfordringene. Alle land bruker en blandning av fiskale (finansielle), regulatoriske og informative virkemidler. Sverige og Danmark fremtrer som landene med mest diversifisert virkemiddelportefølje, mens Norge i hovedsak tilbyr investeringsstøtte. Det viktigste virkemidlet i Finland er frivillige avtaler, kombinert med andre typer av virkemidler.

\section{Uklart hvilke miljømessige effekter virkemidlene har hatt}

Både eksisterende og nåværende virkemidler har blitt evaluert, men i svært varierende grad. Omfang og innretning på gjennomførte evalueringer varierer. På grunn av dette er det vanskelig å identifisere hvilke virkemidler som så langt har vært mest effektive. De aller fleste evalueringene har fokus på hvordan virkemidlene har blitt implementert og administrative problemstillinger, som hvorvidt virkemidlet har vært utløsende, dvs. om det har vært addisjonelt. Faktiske energibesparelser og reduksjoner i utslipp av klimagasser er kun beregnet i noen evalueringer, og hvor dette er gjort viser det seg at faktiske besparelser eller reduksjoner som regel er lavere enn målet for virkemidlet. Flere evalueringer viser at besparelsene sannsynligvis ville ha blitt realisert også uten støtten, dvs. at virkemidlet har hatt en lav addisjonalitet.

\section{Det finnes et økonomisk potensial for mer energieffektive løsninger}

I løpet av de siste 20 åren har energibruken I de nordiske landene utviklet seg på forskjellig vis. Mange av disse forskjellene beror på strukturelle, 
geografiske og politiske forskjeller. Det er imidlertid en felles trend og det er at energibruken I husholdningene har stagnert eller blitt redusert de siste årene. Den observerte utflatningen i energibruken har flere forklaringsfaktorer, herunder økte energipriser, metningstendenser, økt effektivitet, varmere klima og bytte av energikilder.

Men også med et utflatende energibruk er det flere studier som har identifisert en ikke ubetydelig potensial for ytterligere besparelse i bygninger. Disse studiene bruker forskjellig metodikk og forutsetninger, og er derfor vanskelige å sammenligne, samtidig som det er vanskelig å overføre resultatene fra en studie og et land til andre land.

\section{De direkte energibesparelsene kan bli spist opp av rebound effekter}

Rebound effekter, eller tilbakeslag, består av at noe av eller alle forventede besparelser fra økt effektivisering blir spist opp av økt etterspørsel etter energi. Økt effektivitet betyr at energitjenesten blir billigere og man kan da enten bruke mer av den samme tjenesten eller øke forbruket av en annen tjeneste. Flere empiriske studier bekrefter at det finnes en rebound effekt ved nesten alle tiltak for økt energieffektivisering. Størrelsen på denne effekten varierer imidlertid mellom ulike studier. Noen studier hevder at effektene er så små at de kan ses bort fra, mens andre viser at de kan være så store at de raderer den opprinnelige besparelsen. Det er også grunn til å tro at denne effekten er mindre på kort sikt enn på lang sikt, ettersom evnen til å tilpasse seg øker jo lenger sikt man betrakter.

For å unngå rebound effekter bør virkemidlene for økt energieffektivitet rettes inn mot energitjenester med lav priselastisitet, dvs. hvor etterspørselen er lite følsom for prisendringer. Kostnadene for aktøren som gjennomfører en effektivisering, for eksempel investerer i et styringssystem, bør heller ikke bli for lave. Dette betyr bl.a at stor offentlig støtte, som reduserer kostnaden for aktøren, kan gi forholdsvis stor rebound.

\section{Den optimale politikken består av mange forskjellige virkemidler}

Vår gjennomgang viser at det allerede fines en mengde virkemidler som har til hensikt å øke energieffektiviteten, både generelt og for bygninger spesielt. Man kan derfor spørre om det er behov for ytterligere virkemidler og tiltak rettet mot bygninger. Et argument for flere virkemidler er at det fortsatt finnes en mengde barrierer for økt energieffektivitet og at nåværende arbeid med energieffektivisering sannsynligvis er lavere enn hva som er samfunnsmessig optimalt.

Det er imidlertid viktig å være klar over at det alltid vil finnes et energieffektiviseringsgap, dvs. at det alltid vil være et potensial for lønnsomme effektiviseringer/investeringer som ikke blir gjennomført. Gapet oppstår bl.a på grunn av manglende informasjon (uten at dette bør betraktes som en markedsfeil som forsvarer offentlig inngripen) og gitte bud- 
sjettrammer (ikke alle lønnsomme investeringer kan gjennomføres samtidig). I hvor stor grad myndighetene skal bruke politiske virkemidler for å redusere dette gapet er delvis et spørsmål om hvorvidt barrierene faktisk representerer et markedsfeil og delvis om den forventende nytten (redusert energibruk og/eller utslipp av CO2) er større enn kostnadene for å implementere virkemidlet.

\section{Behov for strikte byggeforskrifter}

$\AA$ rette virkemidler mot byggeindustrien er viktig, ettersom selve konstruksjonen og valgt energisystem vil påvirke energietterspørselen for lang tid fremover. En bygning (i hvert fall selve bærekonstruksjonen) kan ha en teknisk levetid som strekker seg fra 10 til flere hundre år, mens funksjonelle tilpasninger og renoveringen som regel kreves vært 10-20. år. For byggeindustrien er det viktig å sikre at det tas hensyn til energi allerede I planeringen, og at dette ikke er noe som kommer på plass først etter at bygningen er ferdig designet. Tiltak rettet mot byggeindustrien bør være rettet mot de spesifikke barrierene I denne sektoren, som strukturelle utfordringer, mangel på kompetanse og finansielle rammer. Relevante virkemidler er kompetansebygging, strikte - og gradvis innskjerpede - byggeforskrifter, samarbeidsprosjekter (f.eks. avtaler mellom industrien og myndighetene) og begrenset finansiell støtte.

\section{Sluttbrukerprisen må reflektere den reelle prisen for energi}

De som bruker bygningene må være stilt overfor de samfunnsmessig "riktige" energiprisene gjennom bruk av skatter eller andre markedsbaserte virkemidler (som grønne eller hvite sertifikater). Hvis riktige priser betyr at sluttbrukerprisen øker kan myndighetene bistå med informasjon om hvorfor prisen øker og om hvordan man kan spare energi, da dette kan gjøre en prisøkning med akseptabel. Informasjon og råd som enten er gratis eller koster lite kan også brukes for å bygge ned informasjonsbarrierer, redusere skepsisen til nye løsninger og de ikke-finansielle kostnadene for å implementere et nytt energisystem. Finansiell støtte til energieffektive investeringer bør brukes med forsiktighet i denne sektoren, ettersom det er en forholdsvis stor risiko for rebound om besparelsene blir for billige.

\section{Offentlig sektor bør gå føre og velge energieffektive løsninger}

Offentlig sektor bør være en føreganger når det gjelder bruk av energi, delvis basert på et behov å "feie for egen dør før man krever at privat sektor skal gjøre det samme. Dette kan bl.a. innebære at offentlige byggeherrer og -eiere inkluderer energieffektivitet i offentlige innkjøp, både i forbindelse med nybygg, renoveringer og ved leie av lokaler. Offentlig 
sektor kan også bidra til lavere priser på energieffektivt utstyr gjennom å fremme markedsintroduksjon og dermed utløse skalaeffekter for leverandørene.

\section{Merking kan redusere problemet med ulike incentiver hos ulike aktører}

For å redusere den barrieren som ulike incentiver hos de som bygger, eier og bruker en bygning trengs det virkemidler som påvirker både tilbudet og etterspørselen etter energieffektive bygg. Obligatorisk energimerking av bygg, slik som EUs direktiv om energieffektivitet I bygg krever, kan stimulere etterspørselen etter bygg med lavt energiforbruk, og også bidra til at byggere og eiere fokuserer på energi i et livsløpsperspektiv, og ikke bare på kostnadene i byggefasen. Men hvorvidt virkemidlet virkelig vil ha effekt er delvis et spørsmål om energiprisene. Hvis energikostnadene utgjør en viktig andel av totale driftskostnader (inkludert for eksempel leie eller rentekostnader) er energimerking sannsynligvis effektivt, hvis ikke vil den ha mindre effekt. For å være effektiv må ordningen i tillegg være troverdig, og det må finnes en form for kontrollmekanisme.

\section{Nytten og kostnadene for nye virkemidler må vurderes nøye}

Før nye virkemidler blir introdusert, bør eksisterende virkemidler gjennomgås nøye med hensikt å identifisere hvis og i tilfelle hvorfor de ikke er tilstrekkelige. Det er også viktig å se på hvordan andre virkemidler og reguleringer påvirker energieffektiviteten. Alle forslag til nye virkemidler må også vurderes nøye for å sikre at nytten er større enn kostnadene for å implementere og administrere de. Her bør det også tas hensyn til om virkemidlet er forventet å ha rebound-effekter. Det er også hensiktsmessig å designe virkemidlene slik at det er mulig å evaluere de i etterkant. 



\section{Appendix 1}

\section{Description of measures in Norway}

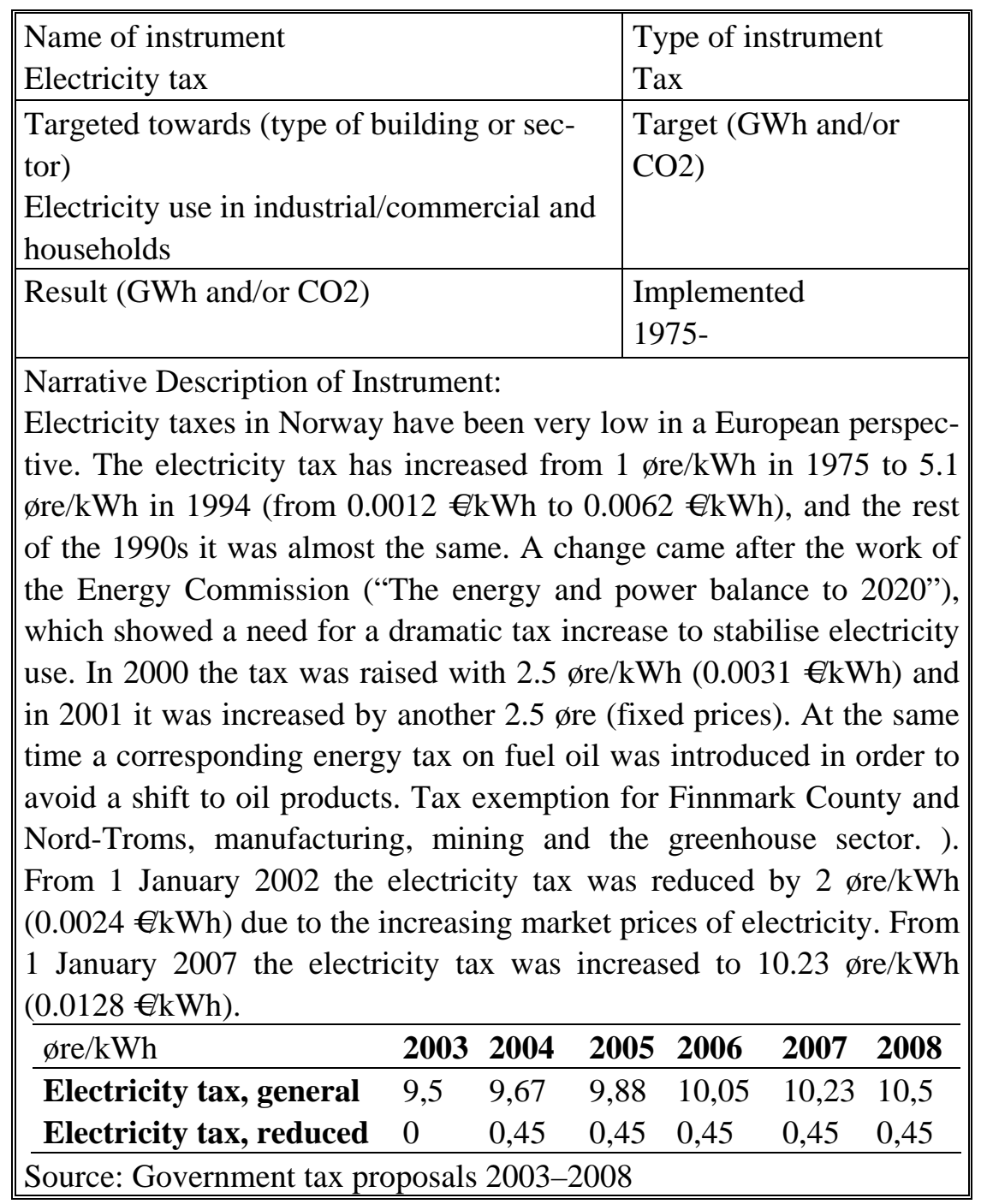




\begin{tabular}{||l|l|}
\hline $\begin{array}{l}\text { Name of instrument } \\
\text { General mineral oil tax }\end{array}$ & $\begin{array}{l}\text { Type of instrument } \\
\text { Tax }\end{array}$ \\
\hline $\begin{array}{l}\text { Targeted towards (type of building or sec- } \\
\text { tor) } \\
\text { All use of mineral oil }\end{array}$ & $\begin{array}{l}\text { Target (GWh and/or } \\
\text { CO2) }\end{array}$ \\
\hline Result (GWh and/or CO2) & Reintroduced 2000 \\
\hline
\end{tabular}

Narrative Description of Instrument:

The general mineral oil tax was re-introduced in 2000, based on the argument that the increase in the tax rate on electricity in 2000 should not contribute to an environmentally unfortunate transfer of consumption of electricity to consumption of oil for heating purposes. This tax includes the consumption of mineral oil, meaning kerosene, gas oil, diesel oil and heating oil.

The tax rate was in 2000 set at the same level as the then increase in the electricity tax, on an øre/kWh level. The tax increased from 0.398 $\mathrm{kr} /$ liter in 2003 to $0.429 \mathrm{kr} /$ liter in 2007. This translates into a tax rate of 5.3 øre/kWh for light fuel oil in 2007. In comparison, the general tax rate on electricity was 10.23 øre/kWh in 2007. According to the tax proposal for 2008 (Finansdepartementet, 2007), equal treatment of different energy carriers means that electricity and mineral oil should have an energy tax at the same level. Therefore, the tax rate on heating oil for 2008 increased by 40.5 øre/liter in addition to normal price adjustments. However, the proposal does not mention that this comparison only is valid for other sectors than the industry, since industry only pays 0.45 øre/kWh.

\begin{tabular}{lllllll}
\hline øre/kWh & $\mathbf{2 0 0 3}$ & $\mathbf{2 0 0 4}$ & $\mathbf{2 0 0 5}$ & $\mathbf{2 0 0 6}$ & $\mathbf{2 0 0 7}$ & $\mathbf{2 0 0 8}$ \\
\hline Light fuel oil & 4,99 & 5,08 & 5,19 & 5,28 & 5,38 & 10,60 \\
Heavy fuel oil & 4,51 & 4,59 & 4,69 & 4,77 & 4,86 & 9,58
\end{tabular}

Source: Government tax proposals 2003-2008 


\begin{tabular}{|c|c|}
\hline $\begin{array}{l}\text { Name of instrument } \\
\mathrm{CO}_{2} \text { tax }\end{array}$ & $\begin{array}{l}\text { Type of instrument } \\
\text { Tax }\end{array}$ \\
\hline $\begin{array}{l}\text { Targeted towards (type of building or sec- } \\
\text { tor): all }\end{array}$ & $\begin{array}{l}\text { Target (GWh and/or } \\
\text { CO2) }\end{array}$ \\
\hline Result (GWh and/or CO2) & $\begin{array}{l}\text { Implemented from } \\
1991\end{array}$ \\
\hline 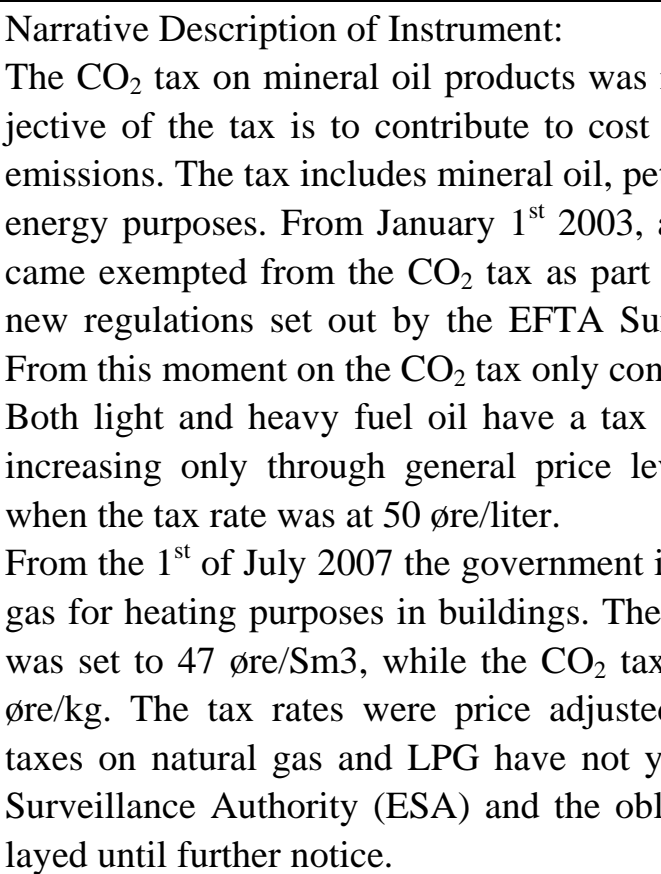 & $\begin{array}{l}\text { roduced in 1991. The ob- } \\
\text { ective reductions of } \mathrm{CO}_{2} \\
\text { l, natural gas and LPG for } \\
\text { use of coal and coke be- } \\
\text { the adaptation process to } \\
\text { illance Authority (ESA). } \\
\text { ms mineral oil products. } \\
\text { e of } 55 \text { øre/liter in 2008, } \\
\text { adjustments since } 2003 \\
\text { oduced a } \mathrm{CO}_{2} \text { tax also on } \\
\mathrm{O}_{2} \text { tax rate on natural gas } \\
\text { te on LPG was set at } 60 \\
\text { or } 2008 \text {. However these } \\
\text { been approved by EFTA } \\
\text { tion to pay has been de- }\end{array}$ \\
\hline
\end{tabular}

\begin{tabular}{l|l|l|l|l|l|l|}
\hline øre/kWh & $\mathbf{2 0 0 3}$ & $\mathbf{2 0 0 4}$ & $\mathbf{2 0 0 5}$ & $\mathbf{2 0 0 6}$ & $\mathbf{2 0 0 7}$ & $\mathbf{2 0 0 8}$ \\
\hline Light fuel oil & 6,27 & 6,40 & 6,52 & 6,65 & 6,77 & 6,90 \\
\hline Heavy fuel oil & 5,67 & 5,78 & 5,90 & 6,01 & 6,12 & 6,24 \\
\hline Light fuel oil & 3,14 & 3,26 & 3,26 & 3,39 & 3,39 & 3,51 \\
\hline Heavy fuel oil & 2,83 & 2,95 & 2,95 & 3,06 & 3,06 & 3,17 \\
\hline Natural gas & 0 & 0 & 0 & 0 & 0 & 6,08 \\
\hline LPG & 0 & 0 & 0 & 0 & 0 & 6,87 \\
\hline
\end{tabular}

Source: Government tax proposals 2003-2008 


\begin{tabular}{|l|l|}
\hline $\begin{array}{l}\text { Name of instrument } \\
\text { Energy use in buildings }\end{array}$ & $\begin{array}{l}\text { Type of instrument } \\
\text { Investment support }\end{array}$ \\
\hline $\begin{array}{l}\text { Targeted towards (type of building or sec- } \\
\text { tor) } \\
\text { Commercial, public, apartments }\end{array}$ & $\begin{array}{l}\text { Target (GWh and/or } \\
\text { CO2) }\end{array}$ \\
\hline Result (GWh and/or CO2) & $\begin{array}{l}\text { Implemented from } \\
\text { 2004- }\end{array}$ \\
\hline $\begin{array}{l}\text { Narrative Description of Instrument: } \\
\text { The program will contribute to permanent market changes in the area } \\
\text { of housing, building and construction. The projects covered by the }\end{array}$ \\
$\begin{array}{l}\text { program are both existing and new commercial buildings and homes, } \\
\text { and construction projects like for example water, drain, road lights and } \\
\text { sports grounds. The support should be additional, implying that Enova } \\
\text { can provide support up to the level where the project achieves a normal } \\
\text { return. The projects compete against each other and projects with the } \\
\text { highest energy return in relation to support level will be given priority. }\end{array}$ \\
$\begin{array}{l}\text { Enova gives as a main rule investment support to physical initiatives, } \\
\text { and the support level is normally between } 0,2 \text { and 0,5 kr/kWh reduced } \\
\text { energy use and/or produced renewable heat annually. }\end{array}$
\end{tabular}

\begin{tabular}{|l|l|}
\hline $\begin{array}{l}\text { Name of instrument } \\
\text { “Introduksjon ny teknologi” (Introduction of } \\
\text { new energy) }\end{array}$ & $\begin{array}{l}\text { Type of instrument } \\
\text { Investment support }\end{array}$ \\
\hline Targeted towards (type of building or sector) & $\begin{array}{l}\text { Target (GWh and/or } \\
\text { CO2) }\end{array}$ \\
\hline Result (GWh and/or CO2) & Implemented from \\
\hline $\begin{array}{l}\text { Narrative Description of Instrument: } \\
\text { In this program Enova provides support to development of more energy } \\
\text { effective technology, but the connection to actual energy savings is } \\
\text { relatively uncertain. }\end{array}$ \\
\hline
\end{tabular}




\begin{tabular}{|l|l||}
\hline $\begin{array}{l}\text { Name of instrument } \\
\text { "Kommunal energi- og miljøplanlegging” } \\
\text { (Municipal energy and environmental plan- } \\
\text { ning) }\end{array}$ & $\begin{array}{l}\text { Type of instrument } \\
\text { Investment support }\end{array}$ \\
\hline $\begin{array}{l}\text { Targeted towards (type of building or sector) } \\
\text { Municipalities }\end{array}$ & $\begin{array}{l}\text { Target (GWh and/or } \\
\text { CO2) }\end{array}$ \\
\hline Result (GWh and/or CO2) & Implemented from \\
\hline $\begin{array}{l}\text { Narrative Description of Instrument: } \\
\text { This program targeting municipal energy and environmental planning } \\
\text { gives support to preparation of municipal energy and environmental } \\
\text { plans and investigation of pre projects for heat production and infra- } \\
\text { structure, in addition to support for pre projects for energy efficiency } \\
\text { and conversion. The municipalities own one fourth of all non- } \\
\text { residential buildings in Norway and counts for one third of the energy } \\
\text { use in Norwegian commercial buildings, which means that the munici- } \\
\text { palities have a great potential to reduce energy use and possibilities for } \\
\text { energy conversion. }\end{array}$ \\
\hline
\end{tabular}

\begin{tabular}{|l|l||}
\hline $\begin{array}{l}\text { Name of instrument } \\
\text { Enovas information activity }\end{array}$ & $\begin{array}{l}\text { Type of instrument } \\
\text { Information }\end{array}$ \\
\hline $\begin{array}{l}\text { Targeted towards (type of building or sector) } \\
\text { All }\end{array}$ & $\begin{array}{l}\text { Target (GWh and/or } \\
\text { CO2) }\end{array}$ \\
\hline Result (GWh and/or CO2) & Implemented from \\
\hline $\begin{array}{l}\text { Narrative Description of Instrument: } \\
\text { Enova has a certain information activity targeting both companies and } \\
\text { households, for example an answering service that among other things } \\
\text { provide energy advices to households. }\end{array}$ \\
\hline
\end{tabular}





\section{Annex II.}

\section{Description of measures in Denmark}

\begin{tabular}{|l|l|}
\hline $\begin{array}{l}\text { Name of instrument } \\
\text { Funding for information activities and cam- } \\
\text { paigns targeted energy savings in building } \\
\text { stock }\end{array}$ & $\begin{array}{l}\text { Type of instrument } \\
\text { Information }\end{array}$ \\
\hline $\begin{array}{l}\text { Targeted towards (type of building or sector) } \\
\text { All building types are eligible }\end{array}$ & $\begin{array}{l}\text { Target (GWh and/or } \\
\text { CO2) } \\
\text { Not specified }\end{array}$ \\
\hline Result (GWh and/or CO2) so far & $\begin{array}{l}\text { Implemented } \\
\text { 2008-2011 }\end{array}$ \\
\hline $\begin{array}{l}\text { Narrative Description of Instrument: } \\
\text { Focus areas: } \\
\text { Energy labelling and how this could form basis for realisation of en- } \\
\text { ergy saving potentials } \\
\text { Awareness raising on the building codes minimum requirements on } \\
\text { energy performance of new buildings and existing buildings undergo- } \\
\text { ing major overhaul/renovation. }\end{array}$ \\
$\begin{array}{l}\text { - Tax registered businesses } \\
\text { - Industry or interest organisations etc. } \\
\text { - Housing societies and associations } \\
\text { - Schools, educational institutions, research institutions etc } \\
\text { - Municipalities and regions, plus municipal and regional institutions } \\
\text { The funds are administered by the DEA. } \\
\text { Target group is: building workers, building industry, building adminis- } \\
\text { trators and building owners. }\end{array}$ \\
\hline
\end{tabular}




\begin{tabular}{|l|l|}
\hline $\begin{array}{l}\text { Name of instrument } \\
\text { Information/research centre on energy sav- } \\
\text { ings in buildings }\end{array}$ & $\begin{array}{l}\text { Type of instrument } \\
\text { Informative }\end{array}$ \\
\hline $\begin{array}{l}\text { Targeted towards (type of building or sector) } \\
\text { All type of buildings }\end{array}$ & $\begin{array}{l}\text { Target (GWh and/or } \\
\text { CO2) } \\
\text { Not specified }\end{array}$ \\
\hline Result (GWh and/or CO2) so far & $\begin{array}{l}\text { Implemented } \\
2008-2011\end{array}$ \\
\hline $\begin{array}{l}\text { Narrative Description of Instrument: } \\
\text { The government put aside 32 mill kr from 2008 until 2011 to establish } \\
\text { and operate the centre, that is a part of the energypolitical deal of Feb- } \\
\text { ruary 2008. The centre will primary approach craftsmen, entre- } \\
\text { prenaurs, advisers, energy consultants, suppliers and smaller compa- } \\
\text { nies in the building industry. }\end{array}$ \\
\hline
\end{tabular}

\begin{tabular}{|l|l||}
\hline $\begin{array}{l}\text { Name of instrument } \\
\text { Energy management by energy distribution } \\
\text { companies }\end{array}$ & $\begin{array}{l}\text { Type of instrument } \\
\text { Legislative/regulation }\end{array}$ \\
\hline $\begin{array}{l}\text { Targeted towards (type of building or sec- } \\
\text { tor) } \\
\text { all sector (public/service, private, industry). }\end{array}$ & $\begin{array}{l}\text { Target (GWh and/or } \\
\text { CO2) }\end{array}$ \\
\hline $\begin{array}{l}\text { Result (GWh and/or CO2) so far } \\
\text { First evaluation by DEA is expected ultimo } \\
2008 .\end{array}$ & $\begin{array}{l}\text { Implemented from and } \\
\text { to } \\
\text { 2006-13 }\end{array}$ \\
\hline $\begin{array}{l}\text { Narrative Description of Instrument: } \\
\text { Regulation inscribed in law and in agreement between the concerned } \\
\text { energy supply companies (except for district heating companies for } \\
\text { which no agreement are made in addition to the regulation by law) and } \\
\text { the DEA The energy companies are free to chose measures for their } \\
\text { energy saving activities meaning that savings along the entire energy } \\
\text { value chain is eligible in all concerned sectors (primary and secondary } \\
\text { energy) as long as they are documented properly according to the re- } \\
\text { quirements laid down. Companies can operate outside own area and } \\
\text { even in other areas of primary/secondary energy (i.e. a district heating } \\
\text { company could account electricity savings and eligible). Binding an- } \\
\text { nual energy saving target is: Electricity supply companies: } 1.4 \text { PJ; Gas } \\
\text { distribution companies: } 0.5 \text { PJ; District heating companies: } 0.9 \text { PJ; } \\
\text { Petroleum supply companies: } 0.15 \text { PJ. According to the power compa- } \\
\text { nies own figures, the results of the first 2.5 year is that 98 percent of } \\
\text { the annual energy saving goal for power supply companies is achieved } \\
\text { (no results for other companies involved is available). }\end{array}$ \\
\hline
\end{tabular}




\begin{tabular}{|l|l|}
\hline Name of instrument: Energisparepulje & $\begin{array}{l}\text { Type of instrument: } \\
\text { Informative }\end{array}$ \\
\hline $\begin{array}{l}\text { Targeted towards (type of building or } \\
\text { sector): Any }\end{array}$ & $\begin{array}{l}\text { Target (GWh and/or } \\
\text { CO2): Not specified }\end{array}$ \\
\hline $\begin{array}{l}\text { Result (GWh and/or CO2) so far: Not esti- } \\
\text { mated }\end{array}$ & $\begin{array}{l}\text { Implemented from and } \\
\text { to: 2005-2008 }\end{array}$ \\
\hline
\end{tabular}

Narrative Description of Instrument:

Funds allocated by power companies - in accordance with agreement made with government - available for supporting local initiatives on dissemination of information on energy savings.

\begin{tabular}{|c|c|}
\hline $\begin{array}{l}\text { Name of instrument } \\
\text { Electricity Saving Trust (Elsparefonden) }\end{array}$ & $\begin{array}{l}\text { Type of instrument } \\
\text { Informative and finan- } \\
\text { cial (grants) }\end{array}$ \\
\hline $\begin{array}{l}\text { Targeted towards (type of building or sector) } \\
\text { Electricity savings in private and public } \\
\text { sector }\end{array}$ & $\begin{array}{l}\text { Target (GWh and/or } \\
\text { CO2) } \\
\text { 2007: 750-800 GWh } \\
\text { electricity \& 2.7 PJ fuel }\end{array}$ \\
\hline $\begin{array}{l}\text { Result (GWh and/or CO2) so far } \\
\text { Most recent evaluation showed electricity } \\
\text { savings due to the trusts operations at } 1,000 \\
\text { GWh in } 2007 \text { and } 6.4 \text { PJ fuel savings. This } \\
\text { is beyond the targets.. }\end{array}$ & $\begin{array}{l}\text { Implemented from and } \\
\text { to } \\
\text { 1996-ongoing }\end{array}$ \\
\hline \multicolumn{2}{|c|}{$\begin{array}{l}\text { Narrative Description of Instrument: } \\
\text { The trust is sourced by the sales of electricity as stipulated by law and } \\
\text { mandated to work with electricity savings in residential and public } \\
\text { sectors. It makes use of innovative measures and campaigns including } \\
\text { procurement competition and voluntary agreements with en- } \\
\text { ergy/building technology providers on phasing out in-efficient tech- } \\
\text { nologies and procurement competition. It has launched a number of } \\
\text { campaigns including some where households replacing old equipment } \\
\text { with energy efficient equipment were offered a monetary compensa- } \\
\text { tion by the trust, but generally the activities of the trust does not in- } \\
\text { volve financial compensations in order to help spur consumers to re- } \\
\text { duce electricity demand. }\end{array}$} \\
\hline
\end{tabular}




\begin{tabular}{|c|c|}
\hline $\begin{array}{l}\text { Name of instrument } \\
\text { Energy savings in state and municipal insti- } \\
\text { tutions }\end{array}$ & $\begin{array}{l}\text { Type of instrument } \\
\text { Legislative/ administra- } \\
\text { tive }\end{array}$ \\
\hline $\begin{array}{l}\text { Targeted towards (type of building or sector) } \\
\text { Government institutions }\end{array}$ & $\begin{array}{l}\text { Target (GWh and/or } \\
\text { CO2) } \\
\text { Not specified }\end{array}$ \\
\hline Result (GWh and/or CO2) so far & $\begin{array}{l}\text { Implemented from and } \\
\text { to: } 2005-\end{array}$ \\
\hline $\begin{array}{l}\text { Narrative Description of Instrument: } \\
\text { For buildings operated by state institutions it } \\
\text { since } 2005 \text { that cost effective energy saving } \\
\text { mandatory energy audit each } 5^{\text {th }} \text { year (as par } \\
\text { buildings) should be implemented if the } \\
\text { building owner is assessed to be lower than } \\
\text { have committed themselves in an agreemen } \\
\text { requirements as those applying to buildings } \\
\text { tions. Further to this, it is mandatory for sta } \\
\text { palities to prioritize energy efficiency in proc } \\
\text { DEA has announced that from July } 2009 \text { the } \\
\text { cost effective measures will not be limited } \\
\text { period lower than } 5 \text { years. In addition, the r } \\
\text { public procurement will be revised to rein } \\
\text { savings in public procurement. }\end{array}$ & $\begin{array}{l}\text { has been required by law } \\
\text { otentials identified by the } \\
\text { of the energy labelling of } \\
\text { ay-back period }{ }^{27} \text { for the } \\
5 \text { year. The municipalities } \\
\text { with DEA to meet same } \\
\text { operated by state institu- } \\
\text { e institutions and munici- } \\
\text { urement. } \\
\text { requirement to implement } \\
\text { those having a pay-back } \\
\text { equirements since } 2005 \text { to } \\
\text { force demand for energy }\end{array}$ \\
\hline
\end{tabular}

${ }^{27}$ Capital cost divided by annual cost savings over lifetime. 


\section{Annex III.}

\section{Description of measures in Sweden}

\begin{tabular}{|l|l||}
\hline $\begin{array}{l}\text { Name of instrument } \\
\text { LIP }\end{array}$ & $\begin{array}{l}\text { Type of instrument } \\
\text { Investment support }\end{array}$ \\
\hline $\begin{array}{l}\text { Targeted towards (type of building or sector) } \\
\text { Premises }\end{array}$ & $\begin{array}{l}\text { Target (GWh and/or } \\
\text { CO2) }\end{array}$ \\
\hline $\begin{array}{l}\text { Result (GWh and/or CO2) } \\
\text { Estimations of future energy savings: 0,23 } \\
\text { TWh/ year (2016) }\end{array}$ & $\begin{array}{l}\text { Implemented from } \\
1997-2007\end{array}$ \\
\hline $\begin{array}{l}\text { Narrative Description of Instrument: } \\
\text { Lokala investeringsprogram (LIP), ie local investment programmes, } \\
\text { are implemented in more than half of Sweden's municipalities. The } \\
\text { programme is part of a government supported systems. It is adminis- } \\
\text { tered by the Naturvårdsverket. Since the start of LIP and KLIMP (see } \\
\text { further down), a total of 22 MSEK has been channelled into environ- } \\
\text { mentally friendly investments. The investments concerns energy effi- } \\
\text { ciency and conversion, cleaner air and water and increased biological } \\
\text { diversity. The objective with LIP is not energy efficiency per se, but } \\
\text { rather reduced pollution to air and water. }\end{array}$ \\
\hline
\end{tabular}

\begin{tabular}{|l|l|}
\hline $\begin{array}{l}\text { Name of instrument } \\
\text { Public procurement }\end{array}$ & $\begin{array}{l}\text { Type of instrument } \\
\text { Administrative }\end{array}$ \\
\hline $\begin{array}{l}\text { Targeted towards (type of building or sec- } \\
\text { tor) } \\
\text { All }\end{array}$ & $\begin{array}{l}\text { Target (GWh and/or } \\
\text { CO2) }\end{array}$ \\
\hline $\begin{array}{l}\text { Result (GWh and/or CO2) } \\
\text { Accumulated saved energy 1995-2005: } \\
4027 \text { Gwh }\end{array}$ & $\begin{array}{l}\text { Implemented from } \\
1990-\end{array}$ \\
\hline $\begin{array}{l}\text { Narrative Description of Instrument: } \\
\text { Technical public procurement has been used as a tool to stimulate the } \\
\text { development of new energy efficient technology since 1990. A total of } \\
55 \text { procurements have been made between 1990 and 2005 by Swedish } \\
\text { Energy Agency and Nutek. }\end{array}$ \\
\hline
\end{tabular}




\begin{tabular}{|c|c|}
\hline $\begin{array}{l}\text { Name of instrument } \\
\text { Energy labelling }\end{array}$ & $\begin{array}{l}\text { Type of instrument } \\
\text { Information }\end{array}$ \\
\hline $\begin{array}{l}\text { Targeted towards (type of building or sector) } \\
\text { One and two dwelling building, multi dwell- } \\
\text { ing buildings (households) }\end{array}$ & $\begin{array}{l}\text { Target (GWh and/or } \\
\text { CO2) }\end{array}$ \\
\hline $\begin{array}{l}\text { Result (GWh and/or CO2) } \\
\text { No real results have been calculated. Swed- } \\
\text { ish Energy Agency however estimate that } \\
\text { Sweden lies slightly above the EU-average } \\
\text { of sold energy efficient households appli- } \\
\text { ances. }\end{array}$ & $\begin{array}{l}\text { Implemented from } \\
1995-\end{array}$ \\
\hline \multicolumn{2}{|c|}{$\begin{array}{l}\text { Narrative Description of Instrument: } \\
\text { The energy labelling was introduced in Sweden in } 1995 \text { and is regu- } \\
\text { lated in the law and by the regulation regarding labelling of household } \\
\text { appliances (SFS 1994:1774). Furthermore, it is also regulated in the } \\
\text { EU by the framework 92/75/EEG. The aim is that the labelling should } \\
\text { guide consumers to choose more energy efficient products and provide } \\
\text { an incentive to producers to develop and produce more energy efficient } \\
\text { appliances. }\end{array}$} \\
\hline
\end{tabular}

\begin{tabular}{|l|l||}
\hline $\begin{array}{l}\text { Name of instrument } \\
\text { Municipal and regional energy advisory } \\
\text { service }\end{array}$ & $\begin{array}{l}\text { Type of instrument } \\
\text { Information }\end{array}$ \\
\hline $\begin{array}{l}\text { Targeted towards (type of building or sector) } \\
\text { All }\end{array}$ & $\begin{array}{l}\text { Target (GWh and/or } \\
\text { CO2) }\end{array}$ \\
\hline $\begin{array}{l}\text { Result (GWh and/or CO2) } \\
\text { No results calculated }\end{array}$ & $\begin{array}{l}\text { Implemented from } \\
1998-\end{array}$ \\
\hline $\begin{array}{l}\text { Narrative Description of Instrument: } \\
\text { Municipal and regional energy advisory services were introduced in } \\
1998 \text { with the aim to increase awareness to consumers regarding en- } \\
\text { ergy in general and energy efficiency in particular. All the Swedish } \\
\text { municipalities have introduced this service, some more extensively } \\
\text { than others. All municipalities report to the Swedish Energy Agency } \\
\text { regarding their activities. Since 2007 the service also includes informa- } \\
\text { tion on boilers, according to EU-directive 2002/91/EG. }\end{array}$ \\
\hline
\end{tabular}




\begin{tabular}{|l|l|}
\hline $\begin{array}{l}\text { Name of instrument } \\
\text { ByggaBo-dialogue }\end{array}$ & $\begin{array}{l}\text { Type of instrument } \\
\text { Administrative }\end{array}$ \\
\hline $\begin{array}{l}\text { Targeted towards (type of building or sector) } \\
\text { All }\end{array}$ & $\begin{array}{l}\text { Target (GWh and/or } \\
\text { CO2) }\end{array}$ \\
\hline $\begin{array}{l}\text { Result (GWh and/or CO2) } \\
\text { No results calculated }\end{array}$ & $\begin{array}{l}\text { Implemented from } \\
1998-\end{array}$ \\
\hline $\begin{array}{l}\text { Narrative Description of Instrument: } \\
\text { The BB dialogue is a voluntary deal between the government and ap- } \\
\text { proximately } 40 \text { actors in the construction sector. Together, these actors } \\
\text { have formulated goals of which one refers to energy efficiency within } \\
\text { the construction sector. This goal is more specifically formulated as: } \\
\text { "Use of bought electricity within the sector should be reduced by 20 } \\
\text { percent by year 2025 compared to 2000. Energy use should be less by } \\
\text { year } 2010 \text { than 1995". It is Boverket who is administering this dia- } \\
\text { logue. }\end{array}$
\end{tabular}

\begin{tabular}{|c|c|}
\hline KLIMP & $\begin{array}{l}\text { Type of instrument } \\
\text { Investment support }\end{array}$ \\
\hline $\begin{array}{l}\text { Targeted towards (type of building or sector) } \\
\text { All (municipalities) }\end{array}$ & $\begin{array}{l}\text { Target (GWh and/or } \\
\text { CO2) }\end{array}$ \\
\hline $\begin{array}{l}\text { Result (GWh and/or CO2) } \\
\text { Estimations of future energy savings: 0,13 } \\
\text { TWh/ year } 2010 \text { 0,05 TWh/year } 2016\end{array}$ & $\begin{array}{l}\text { Implemented from } \\
\text { 1997-2007 }\end{array}$ \\
\hline \multicolumn{2}{|c|}{$\begin{array}{l}\text { Narrative Description of Instrument: } \\
\text { Klimatinvesteringsprogram (KLIMP) are implemented in more than } \\
\text { half of Sweden's municipalities. The programme is part of a govern- } \\
\text { ment supported systems. It is administered by the Naturvårdsverket. } \\
\text { Since the start of LIP and KLIMP, a total of } 22 \text { MSEK has been chan- } \\
\text { nelled into environmentally friendly investments. The investments } \\
\text { concerns energy efficiency and conversion, cleaner air and water and } \\
\text { increased biological diversity. The object of KLIMP is not energy effi- } \\
\text { ciency per se, but rather reduced reductions of pollution. }\end{array}$} \\
\hline
\end{tabular}




\begin{tabular}{|c|c|}
\hline $\begin{array}{l}\text { Name of instrument } \\
\text { Conversion Support to renewable energy } \\
\text { source for public use }\end{array}$ & $\begin{array}{l}\text { Type of instrument } \\
\text { Investment support }\end{array}$ \\
\hline $\begin{array}{l}\text { Targeted towards (type of building or sector) } \\
\text { Premises }\end{array}$ & $\begin{array}{l}\text { Target (GWh and/or } \\
\text { CO2) }\end{array}$ \\
\hline $\begin{array}{l}\text { Result (GWh and/or CO2) } \\
\text { Estimations of future energy savings: } 719 \\
\text { GWh in } 2016\end{array}$ & $\begin{array}{l}\text { Implemented from } \\
\text { 2004-2008 }\end{array}$ \\
\hline $\begin{array}{l}\text { Narrative Description of Instrument: } \\
\text { The owner of premises for public use may sl } \\
\text { support could be granted for the following ei } \\
\text { to } 30 \text { percent of the eligible costs except } \mathrm{f} \\
\text { which } 70 \text { percent could be covered: } \\
\text { Energy mapping; } \\
\text { Conversion from direct heating using elect } \\
\text { newable energy; heating pump of district hea } \\
\text { Connection to district cooling } \\
\text { Installation of electricity effective lighting sy } \\
\text { Installation of electricity effective ventilatior } \\
\text { Installation of equipment for effective } \\
\text { monitoring, regulation and operation of engi } \\
\text { Energy efficiency measures that will result } \\
\text { and } \\
\text { Installation of solar systems. } \\
\text { A maximum of SEK } 10000 \text { may be grantec } \\
\text { of MSEK } 1200 \text { had been granted. }\end{array}$ & $\begin{array}{l}\text { bmit for this support. The } \\
\text { hht measures and cover up } \\
\text { the eight measures, for } \\
\text { icity of fossil fuels to re- } \\
\text { ing; } \\
\text { stem } \\
\text { system } \\
\text { esernance, measurement, } \\
\text { es or heating systems; } \\
\text { better heating recycling, } \\
\text {. Up to early } 2007 \text { a total }\end{array}$ \\
\hline
\end{tabular}

\begin{tabular}{|l|l||}
\hline $\begin{array}{l}\text { Name of instrument } \\
\text { Support to installation of solar heater facility }\end{array}$ & $\begin{array}{l}\text { Type of instrument } \\
\text { Investment support }\end{array}$ \\
\hline $\begin{array}{l}\text { Targeted towards (type of building or sector) } \\
\text { One and two dwelling building }\end{array}$ & $\begin{array}{l}\text { Target (GWh and/or } \\
\text { CO2) }\end{array}$ \\
\hline $\begin{array}{l}\text { Result (GWh and/or CO2) } \\
\text { Estimations: 114 GWh (2016) }\end{array}$ & $\begin{array}{l}\text { Implemented from } \\
2000-2010\end{array}$ \\
\hline $\begin{array}{l}\text { Narrative Description of Instrument: } \\
\text { For household wishing to install a solar heater facility, support can be } \\
\text { granted for projects started 1 June 2000 and it is the respective } \\
\text { Länsstyrelse that administer the conversion support. The size of the } \\
\text { support is limited to the following: } \\
\text { Max } 7500 \text { sek/apartment in one and two dwelling buildings } \\
\text { Max } 5 \text { 000sek/ apartment in multi dwelling buildings } \\
\text { Max } 5 \text { 000sek/premises connected to residential houses }\end{array}$ \\
\hline
\end{tabular}




\begin{tabular}{|l|l|}
\hline $\begin{array}{l}\text { Name of instrument } \\
\text { Support to installation of solar heater facility } \\
\text { in commercial premises }\end{array}$ & $\begin{array}{l}\text { Type of instrument } \\
\text { Investment support }\end{array}$ \\
\hline $\begin{array}{l}\text { Targeted towards (type of building or sector) } \\
\text { Premises }\end{array}$ & $\begin{array}{l}\text { Target (GWh and/or } \\
\text { CO2) }\end{array}$ \\
\hline $\begin{array}{l}\text { Result (GWh and/or CO2) } \\
\text { Estimations of future energy savings: 1,3 } \\
\text { GWh (2016) }\end{array}$ & $\begin{array}{l}\text { Implemented from } \\
\text { 2006-2010 }\end{array}$ \\
\hline $\begin{array}{l}\text { Narrative Description of Instrument: } \\
\text { Owner of premises used for commercial activities may get support for } \\
\text { installation of solar heating facilities. The interest has been much lower } \\
\text { than anticipated. The total support depends on the annually energy } \\
\text { production of the solar facility, according to a formula. SEK 2.5 is } \\
\text { given per produced KWh. There are certain quality requirements to } \\
\text { receive support. }\end{array}$
\end{tabular}

\begin{tabular}{|l|l|}
\hline $\begin{array}{l}\text { Name of instrument } \\
\text { Support for installation of energy efficient } \\
\text { windows }\end{array}$ & $\begin{array}{l}\text { Type of instrument } \\
\text { Investment support }\end{array}$ \\
\hline $\begin{array}{l}\text { Targeted towards (type of building or sector) } \\
\text { One and two dwelling buildings }\end{array}$ & $\begin{array}{l}\text { Target (GWh and/or } \\
\text { CO2) }\end{array}$ \\
\hline $\begin{array}{l}\text { Result (GWh and/or CO2) } \\
\text { Estimations of future energy savings: } 74 \\
\text { GWh (2016) }\end{array}$ & $\begin{array}{l}\text { Implemented from } \\
\text { 2005-2008 }\end{array}$ \\
\hline $\begin{array}{l}\text { Narrative Description of Instrument: } \\
\text { Households may get support to install energy efficient windows. The } \\
\text { support has been very popular and the total subvention sum of MSEK } \\
50 \text { has been used. The support is administered by Boverket. Support is } \\
\text { granted for } 30 \text { percent of cost of material and work or maximum SEK } \\
10 \text { 000. }\end{array}$ \\
\hline
\end{tabular}




\begin{tabular}{|l|l||}
\hline $\begin{array}{l}\text { Name of instrument } \\
\text { Conversion support from direct heating in } \\
\text { households }\end{array}$ & $\begin{array}{l}\text { Type of instrument } \\
\text { Investment support }\end{array}$ \\
\hline $\begin{array}{l}\text { Targeted towards (type of building or sector) } \\
\text { One and two dwelling buildings, multi } \\
\text { dwelling buildings, residential connected } \\
\text { premises }\end{array}$ & $\begin{array}{l}\text { Target (GWh and/or } \\
\text { CO2) }\end{array}$ \\
\hline $\begin{array}{l}\text { Result (GWh and/or CO2) } \\
\text { Estimations of future energy savings: } 1420 \\
\text { Gwh (2016) }\end{array}$ & $\begin{array}{l}\text { Implemented from } \\
\text { 2006-2010 }\end{array}$ \\
\hline $\begin{array}{l}\text { Narrative Description of Instrument: } \\
\text { Households may get support to switch away from electricity heating. } \\
\text { The new heating system must be partly or totally water carried. Sup- } \\
\text { port is granted for } 30 \text { percent of cost of material and work or maximum } \\
\text { SEK } 30 \text { 000. The support is administered by Boverket. }\end{array}$
\end{tabular}

\begin{tabular}{||l|l||}
\hline $\begin{array}{l}\text { Name of instrument } \\
\text { Boverkets bygg och konstruktionsregler } \\
\text { (BBR 06) }\end{array}$ & $\begin{array}{l}\text { Type of instrument } \\
\text { Administrative }\end{array}$ \\
\hline $\begin{array}{l}\text { Targeted towards (type of building or sector) } \\
\text { All }\end{array}$ & $\begin{array}{l}\text { Target (GWh and/or } \\
\text { CO2) }\end{array}$ \\
\hline $\begin{array}{l}\text { Result (GWh and/or CO2) } \\
\text { Estimations of future energy savings: 145 } \\
\text { Gwh (2016) (of which Småhus has 5 Gwh } \\
\text { and Premises the rest) }\end{array}$ & $\begin{array}{l}\text { Implemented from } \\
2006\end{array}$ \\
\hline $\begin{array}{l}\text { Narrative Description of Instrument: } \\
\text { BBR sets the minimum level regarding the energy performance of new } \\
\text { buildings. The regulations were last updated in 2006, partly to reach } \\
\text { the requirements in 2002/91/EG. }\end{array}$
\end{tabular}




\begin{tabular}{|l|l||}
\hline $\begin{array}{l}\text { Name of instrument } \\
\text { Energy Taxes }\end{array}$ & $\begin{array}{l}\text { Type of instrument } \\
\text { Fiscal }\end{array}$ \\
\hline $\begin{array}{l}\text { Targeted towards (type of building or sector) } \\
\text { All }\end{array}$ & $\begin{array}{l}\text { Target (GWh and/or } \\
\text { CO2) }\end{array}$ \\
\hline $\begin{array}{l}\text { Result (GWh and/or CO2) } \\
\text { Estimations of future energy savings for } \\
\text { residential and service sectors: 3,4 TWh } \\
\text { (accumulated 1991-2016) }\end{array}$ & Implemented from \\
\hline $\begin{array}{l}\text { Narrative Description of Instrument: } \\
\text { Energy taxes are central tools in Sweden's work on energy efficiency. } \\
\text { For the sector residential and service three taxes are of importance: } \\
\text { Energy tax, CO2 tax and sulphur tax. In addition to that, VAT is } \\
\text { added. The total income of energy taxes were billion SEK 67 in 2006. }\end{array}$ \\
\hline
\end{tabular}

\begin{tabular}{|l|l|}
\hline $\begin{array}{l}\text { Name of instrument } \\
\text { Stöd för konvertering från oljeuppvärmining } \\
\text { (Conversion support from oil based heating } \\
\text { facilities) }\end{array}$ & $\begin{array}{l}\text { Type of instrument } \\
\text { Investment support }\end{array}$ \\
\hline $\begin{array}{l}\text { Targeted towards (type of building or sector) } \\
\text { One and two dwelling building }\end{array}$ & $\begin{array}{l}\text { Target (GWh and/or } \\
\text { CO2) }\end{array}$ \\
\hline $\begin{array}{l}\text { Result (GWh and/or CO2) } \\
\text { Estimations of future energy savings: 2,3 } \\
\text { TWh (between 2005-2016) }\end{array}$ & $\begin{array}{l}\text { Implemented from } \\
2006-2007\end{array}$ \\
\hline $\begin{array}{l}\text { Narrative Description of Instrument: } \\
\text { Households were given the opportunity to receive a grant if converting } \\
\text { away from oil heating to district heating, bio fuel or heat pumps. A } \\
\text { maximum of SEK 14 000 was granted, or 30 percent of the costs. The } \\
\text { support was very popular and the end date had to be changed from } \\
\text { 2010 to 2007, because the total funding was used. Evaluations have } \\
\text { shown that changing from oil heating is profitable for the household } \\
\text { without the support, whereas there have been question raised whether } \\
\text { this support has been necessary. Boverket was the administrator of the } \\
\text { support. }\end{array}$ \\
\hline
\end{tabular}




\begin{tabular}{|c|c|}
\hline $\begin{array}{l}\text { Name of instrument } \\
\text { Energy Declaration }\end{array}$ & $\begin{array}{l}\text { Type of instrument } \\
\text { Administrative }\end{array}$ \\
\hline $\begin{array}{l}\text { Targeted towards (type of building or sector) } \\
\text { All }\end{array}$ & $\begin{array}{l}\text { Target (GWh and/or } \\
\text { CO2) }\end{array}$ \\
\hline Result (GWh and/or CO2) & $\begin{array}{l}\text { Implemented from } \\
2009\end{array}$ \\
\hline $\begin{array}{l}\text { Narrative Description of Instrument: } \\
\text { As a response to EU-directive 2002/91 e } \\
\text { mandatory from the beginning of 2009. Re } \\
\text { the declaration shall contain information a } \\
\text { possibilities to do efficiency measures and } \\
\text { performance. The following buildings neec } \\
\text { 2009, at the latest: } \\
\text { Special buildings exceeding } 1000 \text { square me } \\
\text { libraries, hospitals. } \\
\text { Buildings with the right of use and enjoym } \\
\text { owned apartments and rented premises. } \\
\text { Buildings being sold, for example one and ty } \\
\text { New buildings }\end{array}$ & $\begin{array}{l}\text { ergy declaration will be } \\
\text { arding energy efficiency, } \\
\text { out energy performance, } \\
\text { eference values of energy } \\
\text { a declaration in January } \\
\text { ters, for example schools, } \\
\text { o dwelling buildings }\end{array}$ \\
\hline
\end{tabular}

\begin{tabular}{||l|l||}
\hline $\begin{array}{l}\text { Name of instrument } \\
\text { Stöd till biobränsleanordningar i nybyggda } \\
\text { småhus (Support to installations of biofuels } \\
\text { facilities) }\end{array}$ & $\begin{array}{l}\text { Type of instrument } \\
\text { Investment support }\end{array}$ \\
\hline $\begin{array}{l}\text { Targeted towards (type of building or sector) } \\
\text { Newly built one and two dwelling building }\end{array}$ & $\begin{array}{l}\text { Target (GWh and/or } \\
\text { CO2) }\end{array}$ \\
\hline Result (GWh and/or CO2) & $\begin{array}{l}\text { Implemented from } \\
\text { 2006-2008 }\end{array}$ \\
\hline $\begin{array}{l}\text { Narrative Description of Instrument: } \\
\text { New built houses are given the opportunity to receive a grant if install- } \\
\text { ing bio fuelled heating installations. The installation must be done the } \\
\text { same year as the house is built. A maximum of SEK 15 000 is granted, } \\
\text { or } 30 \text { percent of the costs. Exceeding SEK 10 000. Boverket is the } \\
\text { administrator of the support. }\end{array}$ \\
\hline
\end{tabular}




\section{Annex IV.}

\section{Description of measures in Finland}

\begin{tabular}{|l|l|}
\hline $\begin{array}{l}\text { Name of instrument } \\
\text { Voluntary energy conservation agreements }\end{array}$ & $\begin{array}{l}\text { Type of instrument } \\
\text { Voluntary agreements, } \\
\text { financial subsidies, in- } \\
\text { formation \& education }\end{array}$ \\
\hline $\begin{array}{l}\text { Targeted towards (type of building or sector) } \\
\text { building sector excl. detached housing }\end{array}$ & Target (GWh and/or \\
CO2)
\end{tabular}




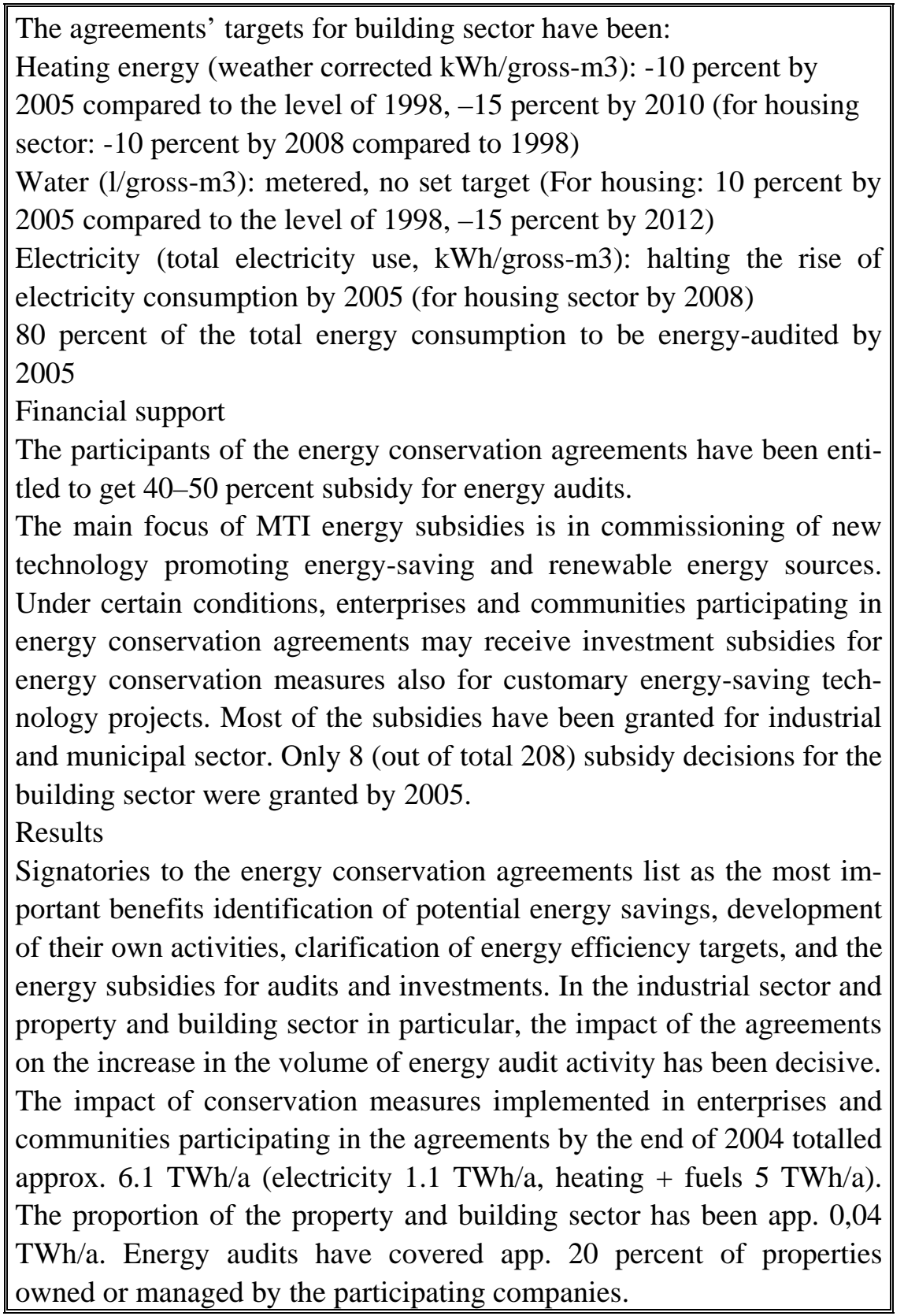




\begin{tabular}{|c|c|}
\hline $\begin{array}{l}\text { Name of instrument } \\
\text { National programme for ecologically sus- } \\
\text { tainable construction }\end{array}$ & $\begin{array}{l}\text { Type of instrument } \\
\text { Program, voluntary }\end{array}$ \\
\hline $\begin{array}{l}\text { Targeted towards (type of building or sector) } \\
\text { Building sector }\end{array}$ & $\begin{array}{l}\text { Target (GWh and/or } \\
\text { CO2) }\end{array}$ \\
\hline $\begin{array}{l}\text { Result (GWh and/or CO2) so far } \\
\text { NA }\end{array}$ & $\begin{array}{l}\text { Implemented } \\
\text { 1998- }\end{array}$ \\
\hline $\begin{array}{l}\text { Narrative Description of Instrument: } \\
\text { In 1998, the Government issued a resolution } \\
\text { ogically sustainable building, which aims at e } \\
\text { considerations as an integral part of decis } \\
\text { building. The programme is based on volunt } \\
\text { drafted jointly with the building and proper } \\
\text { focuses on construction, renovations and m } \\
\text { planning and land-use aspects. } \\
\text { The program has not been evaluated, but Prol } \\
\text { (for buildings) and experimental building ar } \\
\text { gion) are mentioned as examples of progra } \\
\text { vision for Finnish construction and real-estate } \\
\text { 2010) states the desired future for the cluste } \\
\text { level that also energy efficiency is in a key rol }\end{array}$ & $\begin{array}{l}\text { on a Programme for ecol- } \\
\text { stablishing environmental } \\
\text { ion-making processes in } \\
\text { ary participation and was } \\
\text { ty sector. }{ }^{28} \text { The program } \\
\text { laintenance, but excludes } \\
\text { mise environmental rating } \\
\text { ea in Viikki (Helsinki re- } \\
\text { m’s outcomes. A shared } \\
\text { cluster (known as VISIO } \\
\text { and states on a general } \\
\text { e. }\end{array}$ \\
\hline
\end{tabular}

\begin{tabular}{|l|l||}
\hline $\begin{array}{l}\text { Name of instrument } \\
\text { National construction program }\end{array}$ & $\begin{array}{l}\text { Type of instrument } \\
\text { Program }\end{array}$ \\
\hline $\begin{array}{l}\text { Targeted towards (type of building or sector) } \\
\text { Building sector }\end{array}$ & $\begin{array}{l}\text { Target (GWh and/or } \\
\text { CO2) } \\
\text { NA }\end{array}$ \\
\hline $\begin{array}{l}\text { Result (GWh and/or CO2) so far } \\
\text { NA }\end{array}$ & $\begin{array}{l}\text { Implemented } \\
2003-\end{array}$ \\
\hline $\begin{array}{l}\text { Narrative Description of Instrument: } \\
\text { National construction program includes 23 proposals for actions for } \\
\text { construction and real-estate sector, for public sector and for public- } \\
\text { private joint implementation. The broad program includes various as- } \\
\text { pects of which environmental and energy efficiency is one theme. The } \\
\text { proposals for actions don't include quantitative energy (or other) tar- } \\
\text { gets, but outlines on a general level. }\end{array}$ \\
\begin{tabular}{l} 
The program has been evaluated in 2005 and further actions proposed. \\
\hline
\end{tabular} \\
\hline
\end{tabular}

\footnotetext{
${ }^{28}$ http://www.ymparisto.fi/default.asp?node=4779\&lan=en
} 


\begin{tabular}{||l|l|}
\hline $\begin{array}{l}\text { Name of instrument } \\
\text { Energy assistance for housing }\end{array}$ & $\begin{array}{l}\text { Type of instrument } \\
\text { Financial support }\end{array}$ \\
\hline $\begin{array}{l}\text { Targeted towards (type of building or sector) } \\
\text { 1. Detached housing, private households (<2 } \\
\text { households) }\end{array}$ & $\begin{array}{l}\text { Target (GWh and/or } \\
\text { CO2) } \\
\text { 2. Apartment buildings, terraced houses ( }>2 \\
\text { households) }\end{array}$ \\
\hline Result (GWh and/or CO2) so far & $\begin{array}{l}\text { Implemented from and } \\
\text { to }\end{array}$ \\
\hline
\end{tabular}

Narrative Description of Instrument:

1. The energy assistance program is intended for detached housing with max. 2 apartments, used for permanent (all year round) living. The government funded program provided financial assistance for investments in equipment and connection to a disctrict heating network, when the investment results decreased green house gas emissions.

Measures could include: contruction of biofuel-based heating system, terrestrial heating system, complememting of an oil fuelled heating system with solar heating system. The max. amount of subsidy is 10 percent (for connection of district heating) or 15 percent (other investments). Also the owner is entitled to deduce the cost of installation work in his personal taxation.

The subsidy is granted by minicipalities.

2. The energy assistance program is intended for detached housing with min 3 apartments, used for permanent (all year round) living. The government funded program provided financial assistance for energy audits, renewal of the building shell, renewal of the air-conditioning system, and measures linked to heating system and use of renewal energy. Funded measures must be based on energy audit results, exlc. the basic adjustment work of the air conditioning systems.

The subsidy is granted by municipalities, which are in turn funded fy ARA (The Housing Finance and Development Centre of Finland). 


\begin{tabular}{|c|c|}
\hline $\begin{array}{l}\text { Name of instrument } \\
\text { Act on Energy Certification of Buildings } \\
\text { and Ministry of the Environment Decree on } \\
\text { Energy Certification of Buildings }\end{array}$ & $\begin{array}{l}\text { Type of instrument } \\
\text { Legislation }\end{array}$ \\
\hline $\begin{array}{l}\text { Targeted towards (type of building or sector) } \\
\text { All }\end{array}$ & $\begin{array}{l}\text { Target (GWh and/or } \\
\text { CO2) }\end{array}$ \\
\hline $\begin{array}{l}\text { Result (GWh and/or CO2) so far } \\
\text { NA }\end{array}$ & $\begin{array}{l}\text { Implemented } \\
2008-\end{array}$ \\
\hline $\begin{array}{l}\text { Narrative Description of Instrument: } \\
\text { The European Union's Directive on the Ene } \\
\text { ings was implemented in Finland through th } \\
\text { tion of Buildings and Ministry of the Envir } \\
\text { Certification of Buildings. The Act and De } \\
\text { January 2008. The national building regula } \\
\text { were also made more precise with the implen } \\
\text { In connection with the Act, the Ministry } \\
\text { newed Building Codes } \\
\text { An energy certification is required for new } \\
\text { existing buildings, the certificate is required, } \\
\text { or rented. The certificate is given by superil } \\
\text { authorised certifier. }\end{array}$ & $\begin{array}{l}\text { gy Performance of Build- } \\
\text { Act on Energy Certifica- } \\
\text { nment Decree on Energy } \\
\text { ree came into force on } 1 \\
\text { ons on energy efficiency } \\
\text { entation. } \\
\text { Environment issued re- } \\
\text { construction projects. For } \\
\text { when the building is sold } \\
\text { tended, energy auditor or }\end{array}$ \\
\hline
\end{tabular}

